\title{
A systematic approach for major renovation of residential buildings
}

\author{
Linn Liu
}

Division of Energy Systems

Department of Management and Engineering

Linköping University,

SE-581 83 Linköping, Sweden 
A systematic approach for major renovation of residential buildings

LINN LIU

CLinn Liu, 2017

Linköping University Studies in Science and Technology

Dissertation No. 1860

ISBN: 978-91-7685-507-2

ISSN 0345-7524

Distributed by:

Linköping University

Department of Management and Engineering

SE-581 83 Linköping

Sweden

Phone: +46 (0)13-28 1000

Printed by:

LiU-tryck, Linköping, Sweden, 2017

Cover design by Baran Burkay 
This thesis is based on work conducted within the interdisciplinary graduate school Energy Systems. The national Energy Systems Programme aims at creating competence in solving complex energy problems by combining technical and social sciences. The research programme analyses processes for the conversion, transmission and utilisation of energy, combined together in order to fulfil specific needs.

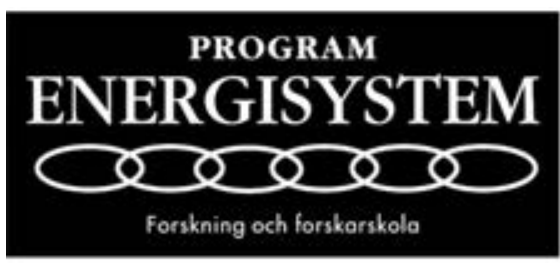

The research groups that constitute the Energy Systems Programme are the Department of Engineering Sciences at Uppsala University, the Division of Energy Systems at Linköping Institute of Technology, the Research Theme Technology and Social Change at Linköping University, the Division of Heat and Power Technology at Chalmers University of Technology in Göteborg as well as the Division of Energy Processes at the Royal Institute of Technology in Stockholm. Associated research groups are the Division of Environmental Systems Analysis at Chalmers University of Technology in Göteborg as well as the Division of Electric Power Systems at the Royal Institute of Technology in Stockholm.

www.liu.se/energi 


\begin{abstract}
In Sweden, buildings are responsible for about $40 \%$ of total energy use and about $10 \%$ of total $\mathrm{CO}_{2}$ emissions. Today more than $60 \%$ of existing Swedish residential buildings are over 40 years old and are in need of major renovation. In addition, $15 \%$ of all multi-family buildings and $27 \%$ of all single-family houses were built before 1945 . The increased energy use and threat from $\mathrm{CO}_{2}$ emissions of the building sector create a need for energy efficiency. The important role that renovation of residential buildings will play in reducing the total energy used by the Swedish building sector as well as in reducing primary energy use and $\mathrm{CO}_{2}$ emissions on both the national and global levels has been the impetus for the studies included in this thesis.
\end{abstract}

The aim of the current research is to develop a methodology from a system perspective which can be used to analyze the energy use, optimal life cycle cost (LCC), energy efficiency measure (EEM) package, indoor environment, $\mathrm{CO}_{2}$ emissions, and primary energy use of a building or a community during major renovation. The developed methodology accomplished at three different levels, i.e. building level, cluster level and district level. The methodology considers both energy efficiency and economic viability during building renovation and will also play an important role in overall urban planning. The studied buildings include both nonlisted and listed residential buildings and the tools used include building energy simulation (BES), survey, technical measurements, LCC optimization and building categorization.

The results show that the combination of BES, technical measurements and surveys provides a holistic approach for evaluation of energy use and indoor environment of the studied residential buildings. The results from the current study also show that the 2020 energy target, i.e., reduction of energy use by $20 \%$, for the building sector can be achieved by all the studied building types and that the total LCC of these buildings are below the cost-optimal point. In comparison, the 2050 energy target, i.e., reduction of energy use by $50 \%$, for the building sector may be achieved by the non-listed buildings, but when the constraints relevant to listed buildings are added the cost-optimality changes as some EEMs in direct conflict with the building's heritage value may not be implemented.

The investigation of primary energy use and $\mathrm{CO}_{2}$ emissions by the residential buildings show that the higher the energy saving, the lower the primary energy use becomes, and vice versa. With the same energy saving, the heating system with higher primary energy factor results in higher primary energy use. From a $\mathrm{CO}_{2}$ emissions point of view, EEM packages proposed to help buildings connected to a CHP based district heating system, to reduce the energy use or LCC are not consistently effective. Since these EEM packages will reduce district heating demand, the electricity produced in the CHP plant will also decrease. When the biomass is considered a limited resource, measures such as investment in a biofuel boiler are not favourable from the $\mathrm{CO}_{2}$ emissions point of view. The current study has also shown that combining building categorization method and LCC optimization method will help the community to reduce its energy use, primary energy use and $\mathrm{CO}_{2}$ emissions in a systematic and strategic way. 


\section{Sammanfattning}

I Sverige, står byggnadssektorn för cirka $40 \%$ av den totala energianvändningen och cirka $10 \%$ av $\mathrm{CO}_{2}$-utsläppen. Idag är mer än $60 \%$ av befintliga svenska bostäder över 40 år gamla och i stort behov av renovering. Dessutom är $15 \%$ av alla flerbostadshus och $27 \%$ av alla småhus byggda före 1945. Den ökade energianvändningen och hotet från $\mathrm{CO}_{2}$-utsläpp från byggsektorn skapar ett behov av energieffektivisering. Grunden för studierna i denna avhandling är den stora betydelse som renoveringen av bostäder har, såväl för att kunna minska den totala energianvändningen som den primärenergianvändningen och $\mathrm{CO}_{2}$-utsläppen på både nationell och global nivå.

Syftet med denna forskning är att utveckla en metodik ur ett systematiskt perspektiv som kan användas för att analysera energianvändning, finna optimal livscykelkostnad (LCC), skapa energieffektiviseringsåtgärdspaket, undersöka inomhusmiljöer, beräkna $\mathrm{CO}_{2}$-utsläpp och primärenergianvändning $i$ en byggnad eller ett samhälle vid omfattande renovering. Den utvecklade metodiken som har använts i de aktuella studierna är på tre olika nivåer: byggnadsnivå, klusternivå och stadsdelsnivå. Metodiken avser både energieffektivitet och ekonomisk lönsamhet vid renovering av byggnader och kommer också att spela en viktig roll i den övergripande stadsplaneringen. De studerande byggnaderna i denna avhandling innefattar både historiska och icke-historiska bostäder. De använda verktygen inkluderar building energy simulering (BES), enkätundersökning, tekniska mätningar, LCC-optimering och byggnadskategorisering.

Resultaten visar att kombinationen av BES, tekniska mätningar och enkätundersökning ger en god helhetsbild för utvärdering av energianvändning och inomhusmiljö av den studerade byggnaden. Resultaten från den aktuella studien visar också att 2020-energimålet, d.v.s. en minskning av energianvändningen med $20 \%$ till 2020 av byggsektorn, kan uppnås i alla undersökta byggnader och att den totala LCC av dessa byggnader ligger under den kostnadsoptimala punkten. I jämförelse, kan 2050-energimålet, d.v.s. en minskning av energianvändningen med $50 \%$ till 2050, kan uppnås i icke-historiska byggnader, men med hänsyn tagen till begränsningarna för historiska byggnader, ändras de kostnadsoptimala lösningarna, eftersom vissa energieffektiviseringsåtgärder är i direkt konflikt med byggnadens kulturhistoriska värde och därför inte kan genomföras.

Undersökningen av primärenergianvändning och $\mathrm{CO}_{2}$-utsläpp i de studerade byggnaderna visar, att ju högre energibesparingen är, desto lägre blir primärenergianvändningen, och vise versa. Med lika mycket energibesparing, resulterar värmesystemet med högre primärenergifaktor i högre primärenergianvändning. Sett från $\mathrm{CO}_{2}$-utsläppssynvinkel, är de energieffektiviseringsåtgärdspaket, som kan hjälpa byggnader anslutna till ett kraftvärmebaserat fjärrvärmesystem att minska energianvändningen eller LCC, inte effektiva, eftersom dessa åtgärdspaket kommer att minska fjärrvärmeanvändningen. Detta leder till att mängden producerad el i ett kraftvärmeverk också kommer att minskas. När biobränsle betraktas som en begränsad resurs, är åtgärder som investering i en biobränslepanna inte energieffektiva från en $\mathrm{CO}_{2}$-utsläppssynvikel. Den aktuella studien visar också att kombinationen av byggnadskategorisering och LCC-optimering kommer att hjälpa 
byggnadssektorn att minska sin energianvändning, primärenergianvändning och $\mathrm{CO}_{2}$-utsläpp på ett systematiskt och strategiskt sätt. 
Ta my family 


\section{Acknowledgements}

This work has been carried out within the research school of Energy Systems Programme. I would like to acknowledge the Swedish Energy Agency for financial support.

First, I would like to express my gratitude to my supervisor, Professor Bahram Moshfegh, for giving me the opportunity to be a PhD student at the Division of Energy Systems at Linköping University. I would like to thank him for introducing me to the research field of energy efficiency of buildings and also for his guidance, support, inspirations and sense of humor during my entire $\mathrm{PhD}$ program. I am grateful for the opportunities to be involved in so many interesting projects from which I have learned a lot.

I would like to thank my co-supervisor, Associate Professor Patrik Rohdin, for introducing me to the IDA ICE program, helping me with the measurements, and also for the fruitful discussions and valuable comments about most of my papers. I would like to thank my cosupervisor, Associate Professor Jan Akander, for helping me with the measurements and for the valuable comments in the Gävle projects. I would like to thank you both for the valuable comments on drafts of this thesis.

I would like to thank Professor Stig-Inge Gustafsson, who introduced me to the OPER-MILP program, for his patience and kindness with all of my questions. I would also like to thank him for the encouragement and for cheering me up when I needed it, as well as for the valuable comments on drafts of the thesis. I would like to thank technician Jakob Rosenqvist at the Division of Energy Systems for helping me with all the measurements, data analysis and valuable comments on the results of my work. Thank you also for joining me on the nice café breaks and lunches when we did the measurements and for always encouraging me and being positive.

I would like to thank Professor Tor Broström and PhD student Petra Eriksson at Uppsala University as well as Associate Professor Mathias Cehlin at Gävle University for valuable comments on the work included in the thesis. Thank you Jossefin Thoresson (Swedish Energy Agency) and Anna Wallsten ( $\mathrm{PhD}$ student at Tema $\mathrm{T}$, Linköping University) for good cooperation. Thank you Tech. Lic Ulf Larsson at Gävle University for all the help.

Thanks to all my colleagues at the Division of Energy Systems, and especially thanks to Elisabeth Larsson for always being so kind and helpful. I would like to thank my "fadder barn" $\mathrm{PhD}$ student Vlatko Milic for all the good teamwork, valuable comments on my work and help. I would like to thank $\mathrm{PhD}$ student Lina La Fleur for good cooperation and all the nice talks. In addition, I would like to thank all the $\mathrm{PhD}$ students at the Division of Energy Systems for all the nice times we had during "fin fika" and the activities for $\mathrm{PhD}$ students only. I wish you all good luck!

I would like to thank my friends Ya Zhang and Zhe Chen, for all the nice lunch talks and moral supports. And also for my friends Huijuan Chen, Xiaojing Wang, Viktoria Jing Björck for support and all the fun we had. 
I would like to thank my parents for always believing in me, and for their support and their endless love. In addition, I would also like to thank my uncle's family for their support.

Finally I would like to thank my partner Baran for believing in me and supporting me so that we could move to Linköping for my $\mathrm{PhD}$ study, and also for helping me with the cover page. And our wonderful children Liam and Kevin, thank your for being patient during the last stressful months and for all the joy you bring. You are the brightest stars in my sky! 


\section{List of appended papers}

\section{Paper I}

Linn Liu, Bahram Moshfegh, Jan Akander, Mathias Cehlin

Comprehensive investigation on energy retrofits in eleven multi-family buildings in

Sweden

Energy and Buildings, 84 (2014) 704-715

\section{Paper II}

Linn Liu, Patrik Rohdin, Bahram Moshfegh

Evaluating indoor environment of a retrofitted multi-family building with improved energy performance in Sweden

Energy and Buildings, 102 (2015) 32-44

\section{Paper III}

Tor Broström, Petra Eriksson, Linn Liu, Patrik Rohdin, Fredrik Ståhl, Bahram Moshfegh

A Method to Assess the Potential for and Consequences of Energy Retrofits in Swedish Historic Buildings

The Historic Environment, Vol. 5, No. 2 (2014) 150-66

\section{Paper IV}

Linn Liu, Patrik Rohdin, Bahram Moshfegh

LCC assessments and environmental impacts on the energy renovation of listed and nonlisted multi-family buildings

Energy and Buildings, 133 (2016) 823-833

\section{Paper V}

Linn Liu, Patrik Rohdin, Bahram Moshfegh

Investigating cost-optimal refurbishment strategies for the medieval district of Visby in

Sweden

Submitted for publication 


\section{Abbreviations}

$\mathrm{ACH}$

BES

CHP

COP

GHG

LCC

NEMP

NMEP

OPERA-MILP

PMV

PPD

SADHP

SAEP
Air Change Rate

Building Energy Simulation

Combined Heat and Power

Coefficient Of Performance

Greenhouse Gas

Life Cycle Cost

Nordic Electricity Mix Production

Nordic Marginal Electricity Produced

Optimal Energy Retrofits Advisory-Mixed Integer Linear Program

Predicted Mean Vote

Predicted Percentage of Dissatisfied

Swedish Average District Heating Production

Swedish Average Electricity Mix Production 


\section{Nomenclature}

A

$A_{\text {window }}$

$C_{1}$

$C_{2}$

$C_{3}$

$C_{4}$

$C_{5}$

$C_{6}$

$\mathrm{C}_{7}$

$C_{\text {insul. }}$

$C_{\text {window }}$

$C_{\text {heating unit }}$

$D_{\text {ex.wall }}$

E

F

G

$n$

P

PV

$r$

$T_{\text {indoor }}$

U

V heated floor area, $\mathrm{m}^{2}$

window area, $\mathrm{m}^{2}$

inevitable cost, $\mathrm{SEK} / \mathrm{m}^{2}$

direct insulation cost, SEK $/ \mathrm{m}^{2}$

direct insulation cost, $\mathrm{SEK} /\left(\mathrm{m}^{2} \cdot \mathrm{m}\right)$

constant, SEK $/ \mathrm{m}^{2}$

constant, SEK

constant, SEK/kW

cost of pipe system, SEK

insulation cost, SEK

cost of window replacement, SEK

cost of heating units, SEK

thickness of the external wall, $\mathrm{cm}$

building's energy use, kWh or MWh

annually recurring cost, SEK

future non-recurring cost, SEK

number of year

power of the heating unit, $\mathrm{kW}$

present value, SEK

real discount rate, $\%$

indoor temperature, ${ }^{\circ} \mathrm{C}$

overall heat transfer coefficient, $\mathrm{W} /\left(\mathrm{m}^{2} \cdot \mathrm{K}\right)$

volume, $\mathrm{m}^{3}$ 


\section{Table of contents}

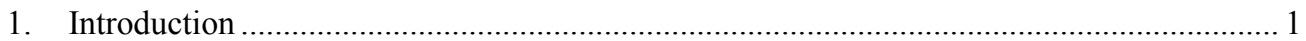

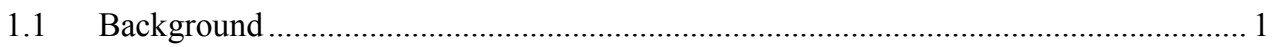

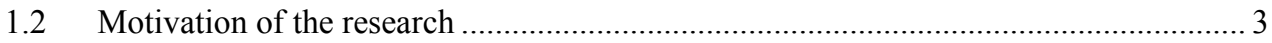

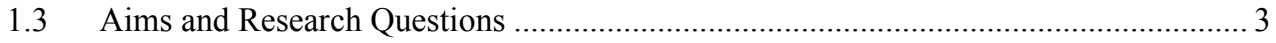

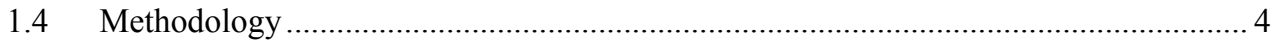

1.5 Research methods and Research Processes ................................................................ 4

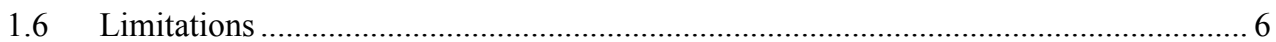

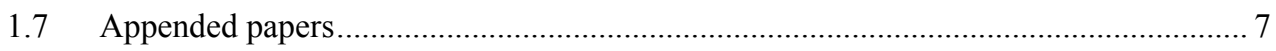

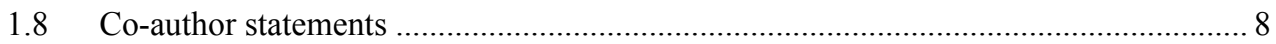

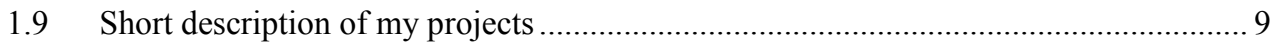

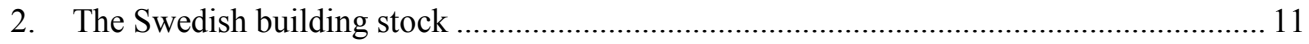

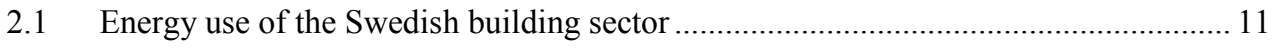

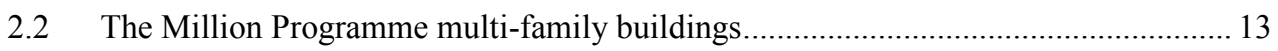

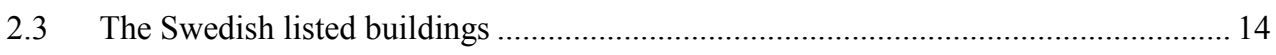

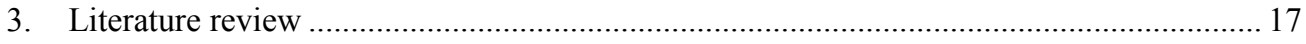

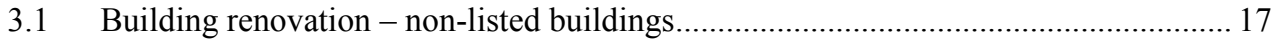

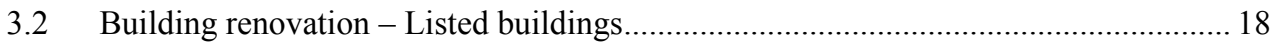

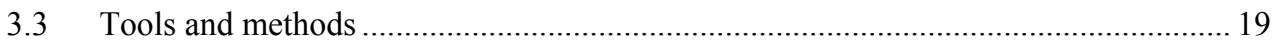

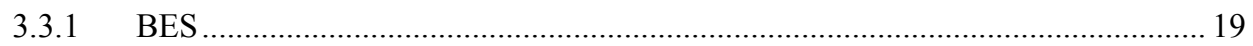

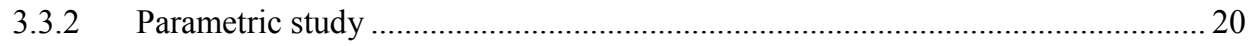

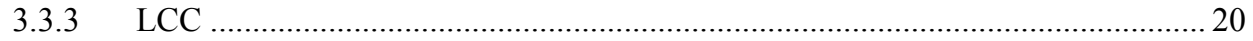

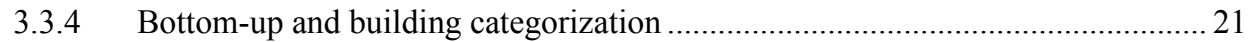

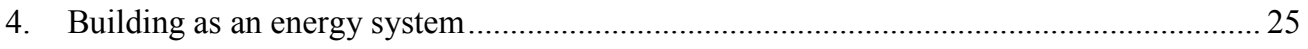

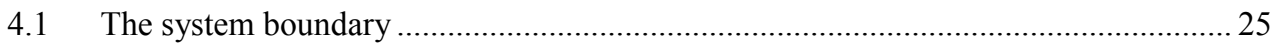

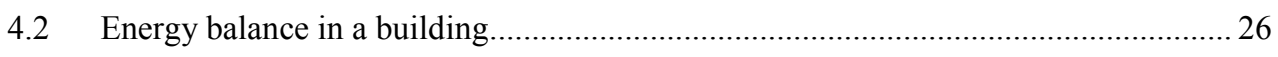

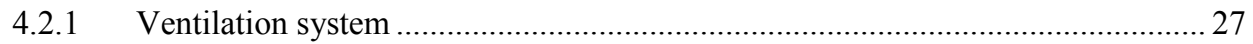

4.2.2 Households' impacts on building's energy use .............................................. 28

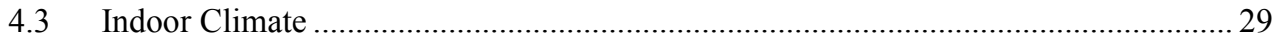

4.4 Energy efficiency measures (EEMs) of buildings ................................................ 30

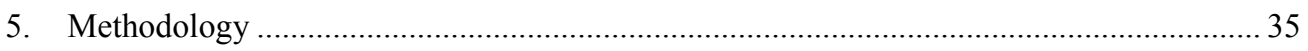

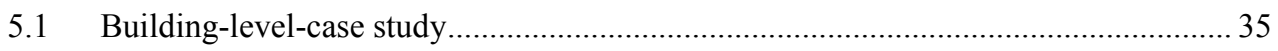

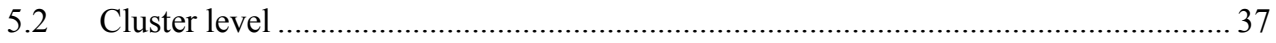

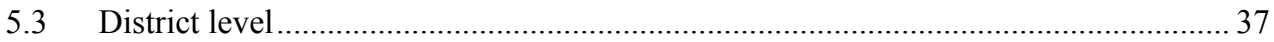




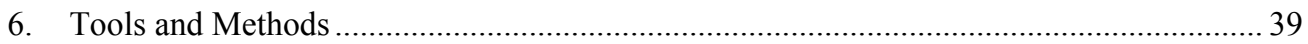

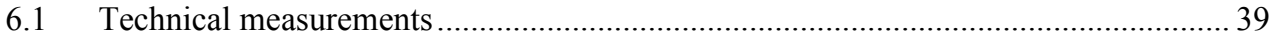

6.1.1 Temperature and humidity measurements ............................................................ 39

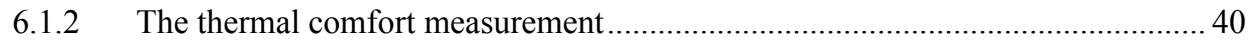

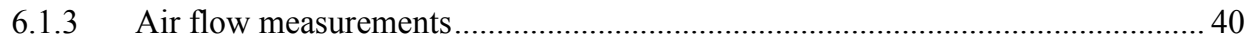

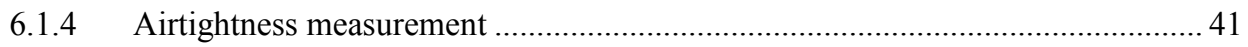

6.1.5 Electricity, space heating and domestic hot water use measurements................. 42

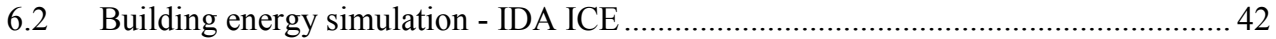

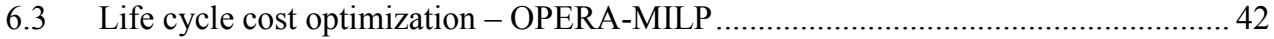

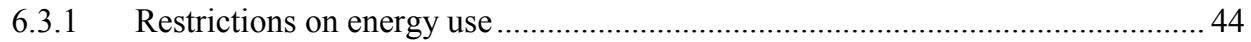

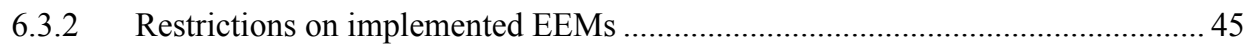

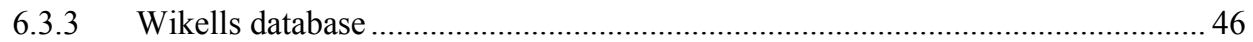

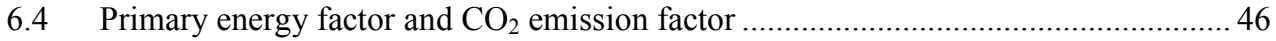

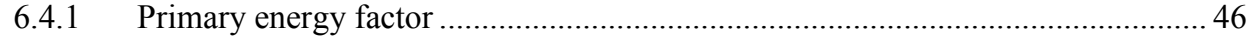

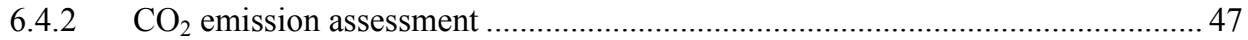

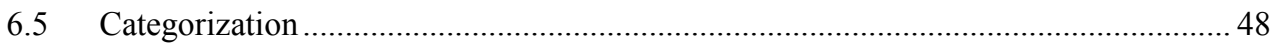

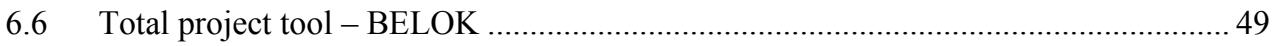

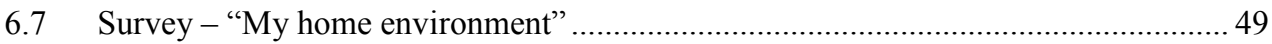

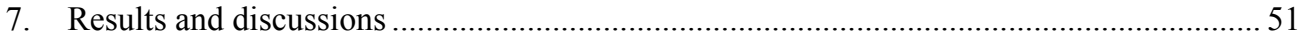

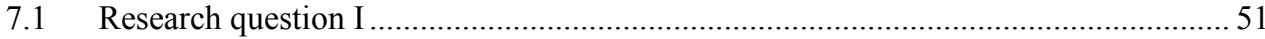

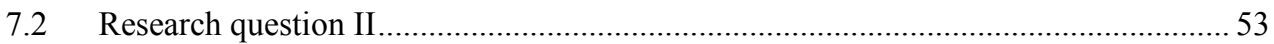

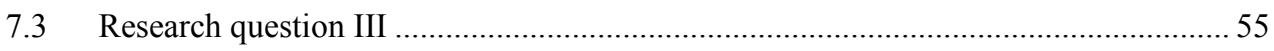

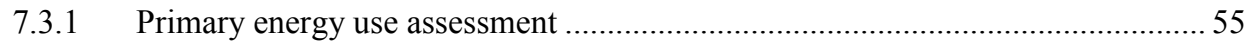

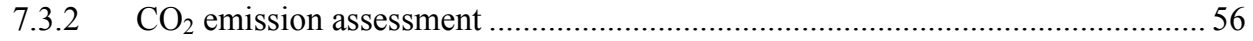

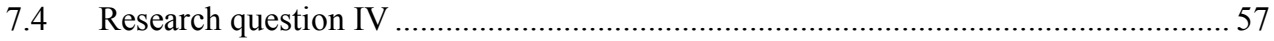

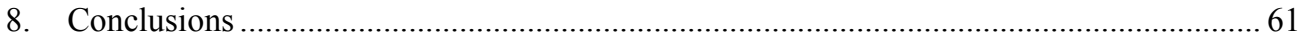

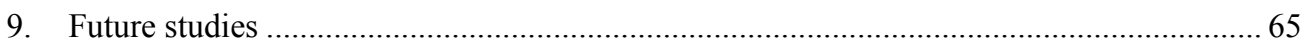

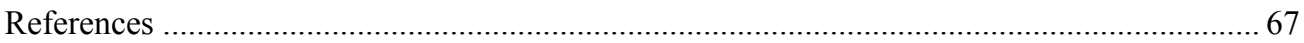




\section{Figures}

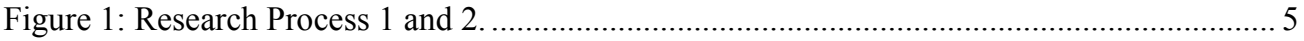

Figure 2: Energy use by the Swedish building and service sector 1970 - 2014 (SEA, 2016a). 12 Figure 3: The total heat demand for single-family, multi-family and commercial buildings in Sweden 2013

Figure 4: The average energy use in $\mathrm{kWh} / \mathrm{m}^{2}$ during 2015 for heating and domestic hot water by Swedish multi-family buildings distributed by year of construction (SEA, 2016b).

Figure 5: The system boundaries used during the current research. Inspired by: Abel \& Elmroth (2007) Buildings and Energy - a systematic approach. ....................................................... 25

Figure 6: Illustration of the methodology developed during the current study. ......................... 35

Figure 7: The three types of LCC optimization with or without additional energy constraints. 45

Figure 8: Restrictions of EEMs for listed (red) and non-listed buildings (black).

Figure 9: Combination of technical measurement, BES and survey to study building's energy use and indoor environment.

Figure 10: LCC, Energy use of listed (triangle) and non-listed (circle) building in the Paper IV.

Figure 11: $\mathrm{CO}_{2}$ emissions by the non-listed building in Paper IV in the reference and LLCC case by using different heating systems.

Figure 12: Overview of the methods application on the studied building stock.

Figure 13: The specific energy use $\left(\mathrm{E} \mathrm{kWh} / \mathrm{m}^{2}\right)$ of Cluster I, II, III \& IV in the reference case.

Figure 14: The total investment cost $\left(\mathrm{SEK} / \mathrm{m}^{2}\right)$ and running cost of cluster I, II, III \& IV in the lowest LCC case (blue: running cost, red: Installation cost, green: Inevitable cost, purple: EEM package).

Figure 15: Saved energy (GWh, blue) and LCC $\left(\mathrm{SEK} / \mathrm{m}^{2}\right.$, red) after implementing different EEM packages on the respective clusters during 50 years. 


\section{Tables}

Table 1: Appended papers, research questions and research processes. ................................... 7

Table 2: Some examples of EEMs related to building's heating system and the corresponding saved energy forms.

31

Table 3: Categorization of the measurements which have been used in building BES models. 52 Table 4: Primary energy use by the non-listed building in the reference case and the lowest

LCC case by using different heating systems. 56 


\section{Introduction}

In this chapter, a short background about the energy use in the building sector globally and nationally, together with a discussion on how to reduce the energy use in this sector is presented. Furthermore, aim and research questions as well as research process and methods are described together with an overview of the appended papers and co-author statements.

\subsection{Background}

Housing is crucial to national development and socio-cultural growth in any human society. Housing is universally acknowledged as the third most essential human need after food and water, and is considered a major economic asset in every nation (Jiboye, 2014). Today's buildings are not only for protection against wind, rain and snow but should also be durable and stable; safe to use; provide protection with regard to hygiene, health and outdoor environment; be accessible and usable for people with impaired mobility; have a good shape, color and material effect, etc. (The Swedish Parliament, 2006).

According to the Intergovernmental Panel on Climate Change (IPCC), buildings accounted for $32 \%$ of total global energy use and $19 \%$ of the energy-related greenhouse gas (GHG) emissions (including electricity-related) in 2010 (IPCC-Buildings, 2014). In Europe, buildings are responsible for $40 \%$ of total energy use and $38 \%$ of the GHG release (European Commission-Energy, 2012). According to a study ordered by IPCC, by 2050 both energy demand in the building sector and $\mathrm{CO}_{2}$ emissions will increase (IPCC-Buildings, 2014). The increased energy use and threat from $\mathrm{CO}_{2}$ emissions of the building sector create a need for energy efficiency. As a consequence, the European Commission has thus set climate and energy targets for 2020 which were enacted in legislation in 2009 (Energy Performance of Building Directive (EPBD)) (Commission-Climate, 2015). The key targets are:

- $20 \%$ cut in GHG emissions (from 1990 levels);

- $20 \%$ of EU energy supply from renewables;

- $20 \%$ improvements in energy efficiency.

In 2013, the EU set another target for Climate and Energy policies (European Commission, 2013) which is called the 2030 framework. The framework outlines the continuation of the important path to energy savings and energy efficiency that member states have already started (Moreci, Ciulla, \& Lo Brano, 2016). According to the framework, the member states have to reduce emissions by $40 \%$ compared to 1990 levels, and promote the production of at least $27 \%$ renewable energy in the EU. Besides, the EPBD has recommended a holistic calculation methodology for major renovations (European Commission-Energy, 2012).

In Sweden, energy use in existing buildings is also high (SEA, 2016a). The building and service sector accounts for $39 \%$ of the total energy use of Sweden, and the industry accounts and transport sectors account for $38 \%$ and $23 \%$ of total energy use of Sweden respectively (SEA, 2016a). According to the Swedish Energy Agency, the average specific energy use by in multi-family buildings was accounted as $136 \mathrm{kWh} / \mathrm{m}^{2}$ during 2015 including heating and 
domestic hot water (SEA, 2016b). The same statistical database has also shown that multifamily buildings built before 1980 have higher than average energy use. The same trend has also been shown for single-family houses and commercial as well as public buildings in Sweden. According to Statistics Sweden, by 2016 more than half of existing Swedish residential buildings are over 40 years old and in great need of renovation (Norlén \& Andersson, 1993). Many of these buildings also have poor energy performance. The common problems with old buildings are high energy use and maintenance cost, inefficient heating and ventilation systems, poor airtightness, draft and cold floors, etc.

People today spend more than $80 \%$ of their time indoors (Hallberg, 2014; Höppe, 2002). Therefore, a good indoor environment is of great importance. According to the Swedish Society for Nature Conservation (SSNC), energy efficient renovations also contribute with increased living standard and better indoor environment (SSNC, 2017). Renovation that converts these buildings into energy-efficient buildings while still providing a proper indoor environment is an important way to reach the national energy targets for buildings (Power, 2008).

In addition, the built environment in Sweden has a large number (15\% of all multi-family buildings and $27 \%$ of all single-family houses) of listed buildings which were built before 1945 (SEA, 2016b). Cultural heritage protection and management in Sweden aims to preserve and manage sites of historical, architectural or archaeological significance and to empower cultural heritage as a force in the evolution of a democratic, sustainable society (Swedish National Heritage Board, 2017). In Sweden, the public cultural heritage management is regulated mainly by the Historic Environment Act (1988:950) and also through the Planning and Building Act (PBL). Listed buildings in this thesis are of historical or cultural importance. Some measures are not allowed in a historic building compare to a normal building. Many listed buildings have lost part of their heritage values due to inappropriate measures such as façade insulation and window replacement (SEA, 2012). The balance between energy conservation and building conservation must be carefully considered (Broström, et al., 2012).

The definition of "major renovation" has been used according to the EPBD revision (European Commission-Energy, 2012):

a) the total cost of the renovation relating to the building envelope or the technical building systems is higher than $25 \%$ of the value of the building, excluding the value of the land upon which the building is situated; or

b) more than $25 \%$ of the surface of the building envelope undergoes renovation." Member States may choose to use either option (a) or (b).

On the contrary there is no definition of "energy renovation" to be found in EPBD. However, in Danish Government (2014), energy renovation has been defined as "a means of improving and developing buildings to meet the needs and challenges of the future and of making homeowners and tenants less vulnerable to rising energy costs in the future". In this thesis energy renovation defines as renovation which will help buildings to achieve better energy efficiency by taking different measures. In other words, energy renovation means taking different 
measures to achieve better energy efficiency for a building that is subjected to major renovation in general.

As a result of implementing the new EU- directive EPBD on building energy use, the Swedish Government proposes that the buildings should reduce their energy use by $20 \%$ by 2020 and $50 \%$ by 2050 compared to energy use in 1995 (SEPA, 2013). The requirements on building's energy use by Swedish Building Regulations (in Swedish: BBR) have become stricter for new buildings and also generally apply to old buildings that will undergo extensive renovation. However, the BBR has made exceptions for the listed buildings: energy efficiency measures planned during a renovation should not change the building's heritage culture value in a way that distorts the building from an historical, environmental and aesthetic point of view (National Board of Housing Building and Planning, 2007).

In the early 2000s, the need for studying buildings as a whole increased in Sweden (J F Karlsson, 2006). The building as an energy system consists of technical systems, residents and organizations. Accordingly, BES plays a significant role in the design and optimization of buildings. BES models, as used in building design, can generally be classified as prognostic law-driven models in that they are used to predict the behaviors of a complex system given a set of well-defined laws (e.g., energy balance, mass balance, conductivity, heat transfer, etc.) (Coakley et al., 2014). In addition, a BES tool can visualize the data such as the built model, hourly and monthly energy use, internal heat generation and energy losses etc. Another recommended concept is the "Total Measure Concept (TMC)" by the Swedish Association of Local Authorities and Regions (UFOS) (UFOS, 2013). The TMC concept considers EEMs as an overall package rather than as individual measures. However, the currently used LCC optimization tool is able to directly find the cost-optimal energy renovation strategy for a building during its whole life cycle, thus making it a better and easier tool to use.

\subsection{Motivation of the research}

The motivation of the current study is the important role that major building renovation plays in reducing the total energy used by the Swedish building sector and also in reducing the primary energy use and $\mathrm{CO}_{2}$ emissions on both the national and global level. By implementing different energy renovation measures, a healthy and comfortable indoor environment will be created. Moreover, the increased interest in finding a cost-optimal solution by using LCC analysis for energy renovation of buildings is another motivation.

\subsection{Aims and Research Questions}

The aim of the current research is to develop a methodology from a system perspective which can be used to analyze the energy use, optimal LCC, energy efficient measure (EEM) package, indoor environment, $\mathrm{CO}_{2}$ emissions, and primary energy use of a building or a cluster of buildings during major renovation.

Four research questions have been considered in order to guide the whole research process:

RQ1. How can BES, technical measurements and surveys to study the energy use and indoor environment of Swedish multi-family buildings be combined? 
RQ2. How can an LCC optimization method be used to a) find cost-optimal EEM packages, b) explore the lowest LCC; and c) reach certain energy targets of the Swedish listed buildings?

RQ3. How can EEMs and building supply energy systems affect the primary energy use and $\mathrm{CO}_{2}$ emissions?

RQ4. How can a categorization strategy and LCC optimization be used to extrapolate the findings from individual buildings to a district level?

\subsection{Methodology}

This thesis takes a system approach to analyze the buildings' energy use and performance during major renovation. A methodology has been developed intended to carry out the study on three different levels (building level, cluster level and district level) by using different tools. The methodology considers both energy efficiency and economic viability during building renovation. Different results can be provided at different levels, which in turn lead to a holistic understanding of the studied building system. This in turn will also lead to avoidance of suboptimization of the building's energy use. The studied objects include listed Swedish residential buildings built before 1945 and non-listed Swedish multi-family buildings.

On the building level, different building types with different construction materials, construction periods and locations have been studied. The advantage of studying different building types is to be able to have a deep level of understanding of the studied objects in terms of the buildings' physical construction, indoor environment, and energy demand as well as LCC and suggested energy efficiency measures.

On the cluster level and district level, an overview of the total energy demand, LCC, costoptimal energy efficiency measures, $\mathrm{CO}_{2}$ emissions and primary energy use of a cluster of buildings can be created. This approach is a bottom-up approach which is achieved through monitoring of sub-metered buildings and through detailed modeling of representative buildings. The results can then be aggregated or up-scaled to the desired level.

\subsection{Research methods and Research Processes}

The research work presented in this thesis integrates a combination of simulation and optimization methods supported by gathered input data to investigate the research questions. The research methods have been used to accomplish the above-mentioned research questions.

Two research processes (RP) 1 and 2 for energy simulation and LCC optimization are illustrated in Figure 1. RP1 is for Papers I and II which include non-listed multi-family buildings and listed buildings and RP2 is for Papers III, IV and V. Paper V up-scales building level results to cluster and district level. Each research process consists of three parts: Data collection, Modelling and Parametric study. The main studies included in RP1 are on building level and include energy and indoor climate analyses, model build-up and validation with questionnaire and technical measurements, which allow parametric studies with EEM (energy and indoor climate improvements). The studies included in RP2 focus on restrictions of specific energy use targets and EEM application in terms of economy, regulations (listed buildings), 
types of buildings (categorization), emissions and influence on the energy systems (local and on the larger scale).

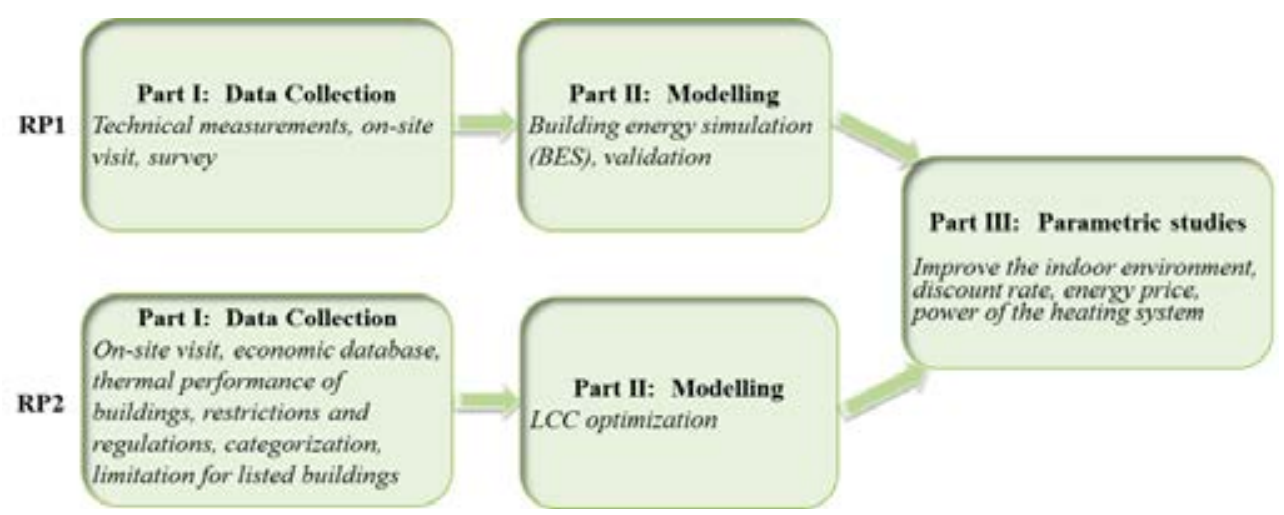

Figure 1: Research Process 1 and 2.

In the first research process (RP1), part I is composed of different forms of data collection: technical measurements, energy use utility bill analysis, and compilation of survey results. In addition, other information such as construction period, appearance of the building, location, etc. have been gathered by on-site visits. Some examples of technical measurements are: indoor temperature, indoor humidity, supply and exhaust air flow, efficiency of ventilation system, airtightness, etc. Some of the measured data from technical measurements will be used as input data of the BES models and some of the measured data will be used for validating the built simulation models. The MM survey "Min boende miljö" ("My home environment") used is an example of a standardized epidemiological survey that has been widely used in Sweden (Andersson et al., 1988). The results from the survey will be used for comparing with the simulation results and also for making suggestions for parametric studies. Part II, "Modelling" will provide information such as total energy use, indoor climate, $\mathrm{CO}_{2}$ emissions, primary energy use by the built models.

A general simulation environment with building energy application called IDA Indoor Climate and Energy (ICE), which is a dynamic simulation tool, has been used for modelling building energy performance (Björsell et al., 1999). This tool has been developed, tested and validated in a number of research projects, see for example: Molin et al., 2011; Rohdin et al., 2012; Rohdin et al., 2014; Wang \& Holmberg, 2014; Olsson et al., 2016; Andersen et al., 2016; Hong et al., 2016. LCC analysis is a method which can be used to find comparable costs for different investment alternatives and operational costs in the long term.

In the appended Paper I, BES, LCC analysis and energy economic viability assessment has been done for a number of multi-family buildings erected during the last 50 years. The combination of BES, technical measurements and survey has been used in the appended Paper II. In order for BES models to be used with any degree of confidence, it is necessary that the existing model closely represent the actual behavior of the building under study (Coakley et al., 2014). In the current study, to validate the built model, the building energy model has been compared to the metering and auditing data. When the simulated model has been validated, the parametric study which describes and examines how a certain parameter can affect the built 
model will be done. In Paper II, the parametric study is about finding solutions for the overheating problem of the studied building during summer, adding external blinds on the windows,

In the second research process (RP2), the input data are collected by using Wikell Section database (a Swedish economic database), making categorization and studying the thermal performance of the building. By using restrictions and regulation the input data such as internal heat generation and average hot tap water used per person in Sweden can be found. By using Wikell Section database, costs of implementing different EEM and installation of different heating systems will be found. By studying the thermal performance of the building, $U$-values of building's different construction parts will be found. In the "Modelling" part, a so-called "categorization" method has been used in order to identify typical buildings which will represent all of the studied buildings in a district.

A software called OPERA-MILP (Optimal Energy Retrofits Advisory-Mixed Integer Linear Program) (Gustafsson, 1988) has also been used in order to find the cost-optimal energy renovation strategy for a building during its whole life cycle. The results which will be provided include building's monthly energy use, LCC, EEM package, $\mathrm{CO}_{2}$ emissions and primary energy use, etc. In the appended Papers III, IV and V, LCC optimization has been mainly used. The parametric study in the third step includes variation of discount rate, energy price and power of the heating systems for the purpose of analyzing how the changed parameters will influence the building's energy use, LCC and EEM package, see appended Papers IV and V. Furthermore, as mentioned above, the last appended paper will up-scale results such as energy use and LCC from building level to cluster and district levels.

\subsection{Limitations}

This study is mainly based on different case studies which include both individual buildings and clusters of buildings. The studied objects are only residential buildings which have great need of renovation, i.e., no industrial buildings or commercial/public buildings are considered. The studies of buildings' energy use and LCC include ventilation system, heating system, airtightness, building thermal performance and residents' behaviors. The management of building during renovation is not included. In RP1 (see Figure 1), when studying the indoor environment, parameters such as lighting, sound and pollutants are not taken into consideration. Acoustic and visual comfort have not been taken into consideration during the study of indoor environment either. Cooling demand is not considered in the analysis. The occupants' activities and human behaviors in terms of opening windows have not been considered either. The building's heritage value has not been considered in this research process.

In RP2 (see Figure 1), validation of the built model and indoor environment study are not included. When studying the climate impact only $\mathrm{CO}_{2}$ emissions have been considered. When calculating the LCC by using OPERA-MILP, the planning cost and maintenance costs are not included in the total LCC. Inflation and impacts on energy prices by cyclical have not been considered either. However, there is a plan for the development of the software OPRA-MILP, more functions will be added. 


\subsection{Appended papers}

This thesis includes the following five papers:

\section{Paper I}

Linn Liu, Bahram Moshfegh, Jan Akander, Mathias Cehlin

Comprehensive investigation on energy retrofits in eleven multi-family buildings in Sweden

Energy and Buildings, 84 (2014) 704-715

\section{Paper II}

Linn Liu, Patrik Rohdin, Bahram Moshfegh

Evaluating indoor environment of a retrofitted multi-family building with improved energy performance in Sweden

Energy and Buildings, 102 (2015) 32-44

\section{Paper III}

Tor Broström, Petra Eriksson, Linn Liu, Patrik Rohdin, Fredrik Ståhl, Bahram Moshfegh

A Method to Assess the Potential for and Consequences of Energy Retrofits in Swedish Historic Buildings

The Historic Environment, Vol. 5, No. 2 (2014) 150-66

\section{Paper IV}

Linn Liu, Patrik Rohdin, Bahram Moshfegh

LCC assessments and environmental impacts on the energy renovation of listed and nonlisted multi-family buildings

Energy and Buildings, 133 (2016) 823-833

\section{Paper V}

Linn Liu, Patrik Rohdin, Bahram Moshfegh

Investigating cost-optimal refurbishment strategies for the medieval district of Visby in Sweden

Submitted for publication

Table 1 shows which research question(s) each paper has answered and in which research process each paper belongs to.

Table 1: Appended papers, research questions and research processes.

\begin{tabular}{l|cccc|cc}
\hline \hline & RQ1 & RQ2 & RQ3 & RQ4 & RP 1 & RP2 \\
\hline Paper I & $\times$ & & $\times$ & & $\times$ & \\
\hline Paper II & $\times$ & & $\times$ & & $\times$ & \\
\hline Paper III & & $\times$ & $\times$ & & & $\times$ \\
\hline Paper IV & & $\times$ & $\times$ & & & $\times$ \\
\hline Paper V & & $\times$ & $\times$ & $\times$ & & $\times$ \\
\hline \hline
\end{tabular}


Paper I: The aim of this paper is to show examples of measures that can be taken in order to achieve a significant reduction in energy use for each individual building. To assess the energy economic viability of these packages, the BELOK Total Project tool is used. The results include different energy efficiency measure packages, profitability analysis of individual measures and packages, and primary energy use analysis. The paper also includes $\mathrm{CO}_{2}$ emissions reduction analysis based on different EEM alternatives.

Paper II: In this paper, a retrofitted multi-family building, located in the city of Linköping, Sweden, was chosen as the study object. The building represents a common type of construction for a multi-family building in Sweden. This paper presents an evaluation of both the indoor environment and energy use of the retrofitted building in comparison with a similar non-retrofitted building.

Paper III: The first part of this paper presents an iterative and interactive method to assess the potential for and consequences of improving the energy performance in a stock of historic buildings. Key elements in the method are: categorization of the building stock, identifying targets, assessment of measures, and life-cycle cost optimization. In the second part of the paper, the method is applied to a typical Swedish building.

Paper IV: The 2020 and 2050 energy targets increase requirements on energy performance in the building stock, thus affecting both listed and non-listed buildings. It is important to select appropriate and cost-optimal EEMs, using e.g. LCC optimization. The aim of this paper is to find cost-optimal packages of EEMs as well as to explore the effects of specific predesigned energy target values for a listed Swedish multi-family building from the 1890s. The purpose is also to show the effects on energy use, $\mathrm{LCC}$, primary energy use and $\mathrm{CO}_{2}$ emissions of different energy targets, discount rates, electricity prices and geographic locations.

Paper V: This paper presents a methodology, using Life Cycle Cost (LCC) optimization and building categorization, to achieve a systematic study of the cost-optimal energy efficiency potential (CEEP) for 920 listed buildings in the medieval district of Visby in Sweden. The aim is to study the CEEP and $\mathrm{CO}_{2}$ emission reductions for this city that is included in the World Heritage List by UNESCO.

\subsection{Co-author statements}

Paper I was written by the thesis author. Professor Bahram Moshfegh, Associate Professor Jan Akander and Associate Professor Mathias Cehlin were involved with project planning, data gathering, results evaluation and also contributed valuable comments on the drafts of the paper. The data were gathered from the project Energy efficiency and profitability of multi-family buildings in the Gävleborg region in Sweden (EKG-f).

Paper III was planned and written in collaboration with Uppsala University and Technical Research Institute of Sweden (SP). Professor Tor Broström and PhD student Petra Eriksson from Uppsala University contributed investigation of policies for Swedish listed buildings and assessment of the building's heritage value and vulnerability. PhD student Linn Liu, Professor Bahram Moshfegh and Associate Professor Patrik Rohdin contributed to finding cost-optimal renovation strategies for the studied building. Researcher Fredrik Ståhl from RICE - Research 
Institutes of Sweden contributed with assessment of hygrothermal risks, indoor climate and durability.

Papers II, IV and V were written by the thesis author. Professor Bahram Moshfegh and Associated Professor Patrik Rohdin were involved in project planning, results evaluation and also contributed valuable comments.

\subsection{Short description of my projects}

During my research, I have been involved in four projects. Since different projects have different aims, different study objects and methods have been used. My first project (2011) was an interdisciplinary project done in collaboration with Dr. Josefin Thoresson and $\mathrm{PhD}$ student Anna Wallsten at the Department of Technology and Social Change at Linköping University. The project was to investigate the driving forces and barriers to energy saving in renovation of a multifamily building in Linköping, Sweden. My focus in this project was to investigate how the heat, electricity, domestic hot water and indoor environment have changed after the renovation of the building. Technical measurements, building energy simulation and questionnaire have been used. The second appended paper (Paper II) was written based on this project.

The second project (2012-2014) was "Climate Neutral and Competitive Gävleborg Region 2050". The project was done in collaboration between the Swedish Energy Agency (SEA), County Administrative Board of Gävleborg Region and the University of Gävle. My focus in this project was a) to investigate the energy performance of the multi-family buildings and single-family houses in the Gävleborg Region; b) to investigate the energy efficiency potential of the buildings; and c) to investigate $\mathrm{CO}_{2}$ emissions and primary energy use of the buildings. During this project, a data-base from the National Board of Housing, Building and Planning which is called Gripen has been used. The final report, "Klimatneutralt och Konkurrenskraftigt Gävleborg 2050 - Byggnader” (Climate Neutral and Competitive Gävleborg 2050 - Buildings) was written based on this project.

The third project (2012-2014) was "Energy efficiency potential of multi-family buildings in the Gävleborg region". The aim of the project was a) to investigate the possibilities to reduce the energy use of multi-family buildings in Gävleborg region by $50 \%$; b) to evaluate the life cycle costs of different energy efficiency measures; and c) to investigate possibilities of $\mathrm{CO}_{2}$ reduction and primary energy use of the multi-family buildings in the Gävleborg region. The methods used were technical measurements, building energy simulation and life cycle cost account. The first appended paper (Paper I) was written based on this project.

The fourth project was "Potentials and policy" (2012-2014). The project was carried out by University of Uppsala (former Gotland University), Linköping University and RICE Research Institutes of Sweden. My focus was a) to evaluate whether the studied building(s) will reach the national energy target while at the same time conserving the buildings' culture heritage value; and b) to evaluate the environmental impact and primary energy use of the studied building(s). Life cycle cost optimization method has been mainly used in this project. The third, fourth and fifth appended papers (Paper III, IV \& V) were written based on this project. 


\section{The Swedish building stock}

This chapter includes a general description of the energy use of the Swedish building sector. Furthermore, the energy performance of the Swedish Million Programme buildings and listed buildings will also be presented.

In Sweden, building technology has developed rapidly in recent decades. Since the oil crisis in the 1970s, the Swedish government has introduced more rigorous building regulations with regard to thermal insulation, airtightness and heat recovery, which can be seen by comparing the BBR from 2010 and 2016 (Boverket, 2010a, 2016). Today's building techniques have more focus on insulation and air tightness, moisture and minimization of thermal bridges, which together will create a better indoor climate and also reduce the building's energy use (Abel \& Elmroth, 2007). Concerning the European policies in buildings' energy use, the Swedish Government proposes that the total energy use per heated area of a building should decrease. As shown in Chapter 1, there is a great potential for residential buildings to reduce energy use by major renovation. A general description of the energy use of different types of building sector in Sweden will be found in the following section.

\subsection{Energy use of the Swedish building sector}

In Sweden, the building and service sector accounted for $39 \%$ (146 TWh) of the total energy use, which was 375 TWh by 2015 (SEA, 2016a). Residential buildings account for $72 \%$ of the total energy use for heating and hot tap water by 2015 (SEA, 2016b).

The energy use by the Swedish building and service sector has been reduced during the 2000 s which is shown in Figure 2. The total energy use by the Swedish building and service sector was 165 TWh during 1970 . On the contrary, it has reduced to 146 TWh during 2014 by $12 \%$. The increased energy use during 2010 was due to lower outdoor temperature than the normal year. Figure 2 also shows that the oil utilization by this sector has been reduced by almost $70 \%$ since 1970 . One reason is that the number of buildings heated by electricity has increased. Another reason is increased use of district heating by this sector. As shown in Figure 2 , electricity is mostly used by the building sector followed by district heating which has increased and becomes higher than oil during the mid1990s.

According to Statistic Sweden, $18 \%$ of multi-family buildings and single-family houses were built before 1965, $34 \%$ between 1965 and 1974, $26 \%$ between 1975 and 1990 and finally $22 \%$ between 1999 and 2014 (SCB, 2015). Buildings are very long-lived and a large proportion of the existing building stock today is in great need of renovation. Since older buildings typically undergo major renovation only every 30 to 40 years, the opportunity of improving energy performance during renovation should be considered seriously (SABO, 2009). It is essential to select appropriate cost-effective energy conservation measures in order to improve the building sector's energy efficiency and to reduce the $\mathrm{CO}_{2}$ emissions and primary energy use by the building sector. 


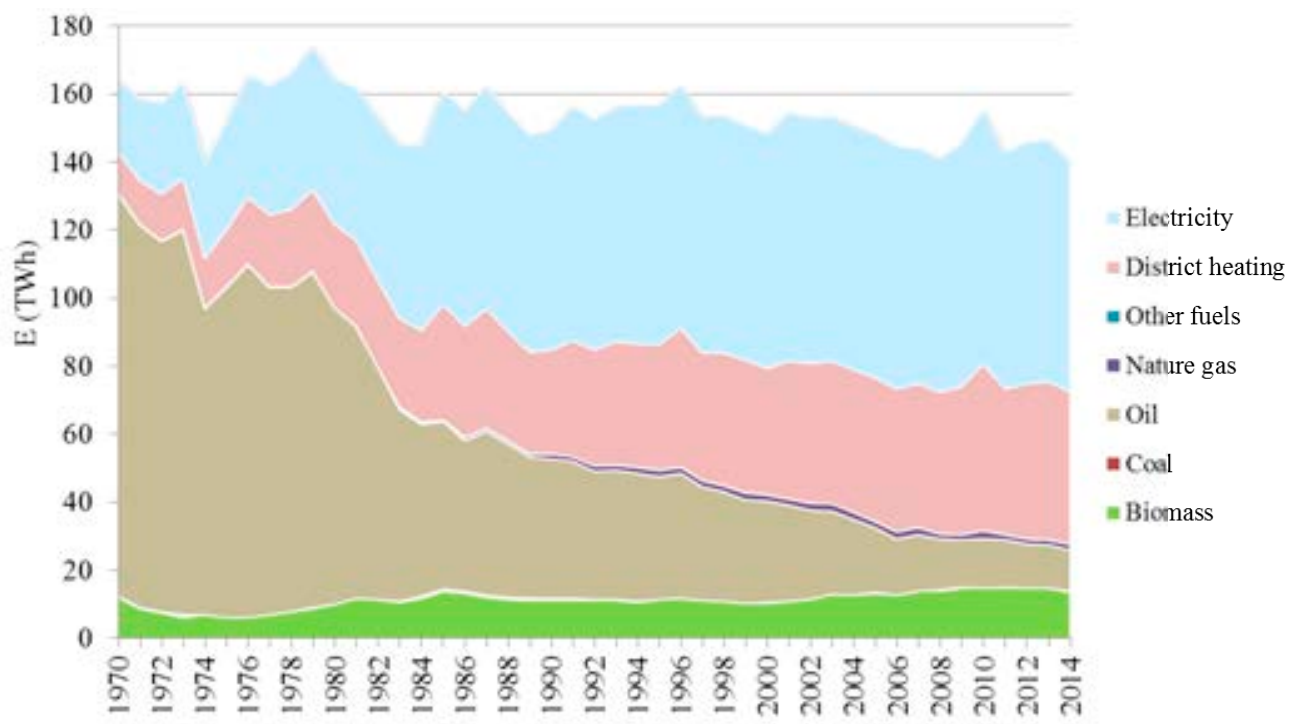

Figure 2: Energy use by the Swedish building and service sector 1970 - 2014 (SEA, 2016a).

Figure 3 shows the total heat demand ${ }^{1}$ by Swedish single-family, multi-family and commercial buildings during 2013. During 2013, the total heat demand by the Swedish buildings was reported as $80.2 \mathrm{TWh}$, where the single-family buildings accounted for $41 \%$ while the multi-family buildings and commercial buildings accounted for $31 \%$ and $28 \%$ respectively.

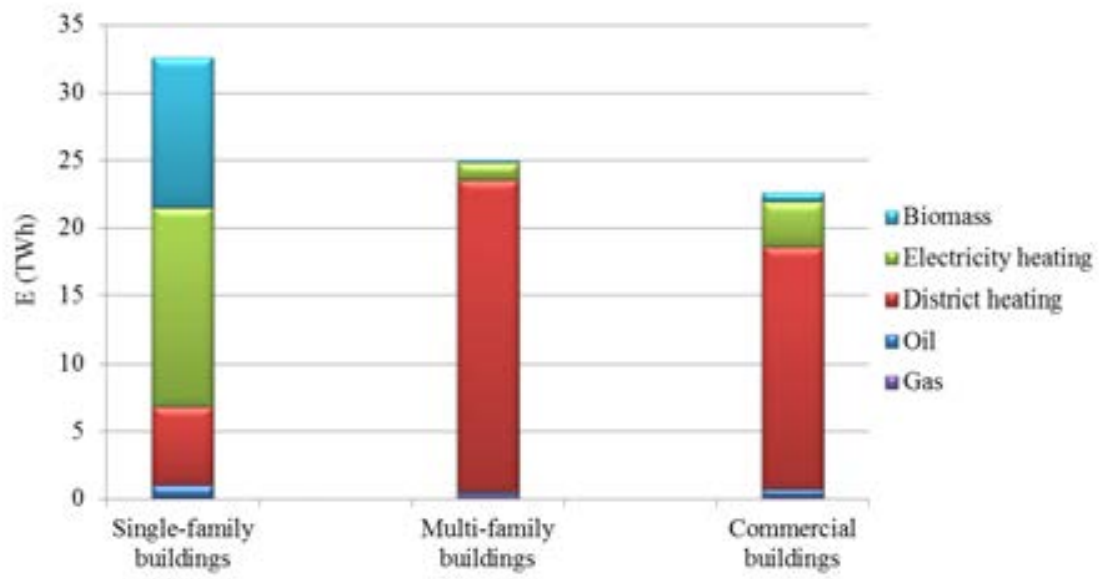

Figure 3: The total heat demand for single-family, multi-family and commercial buildings in Sweden 2013.

As it shows in Figure 3, district heating has been the most common heating method used in both multi-family buildings and commercial buildings, while electricity has remained the most common heating method used in single-family buildings (SEA, 2016a). One reason is as

\footnotetext{
${ }^{1}$ The total heat demand: heating and domestic hot water (DHW) use of a building.
} 
mentioned above that the number of single-family buildings heated by electricity has increased steadily from the 1990s due to conversion from oil heating. Between 2009 and 2013, $52 \%$ of all single-family houses in Sweden have installed heat pumps in one form or other. According to Swedish Energy Agency, for the single-family buildings, the use of biomass such as pellets and wood chips has been increased during the recent years but has declined during the last two years. The biomass use by single-family houses for heating and domestic hot water was 13 TWh during 2009, but it has been reduced to 11.1 TWh by 2013. For multi-family buildings and commercial buildings, heating by electricity was the second most common heating method. The statistic also shows that the oil used for heating and DHW continues to decrease for all three building types (SEA, 2016a). In the following sections the Million Programme multifamily buildings and listed buildings will be introduced.

\subsection{The Million Programme multi-family buildings}

According to the Swedish Energy Agency, the average specific energy use by a multifamily building was reported as $136 \mathrm{kWh} / \mathrm{m}^{2}$, during 2015, including heating and domestic hot water (SEA, 2016b). Multi-family buildings built during the 1960s or earlier are shown to use more energy than the buildings constructed later, according to Figure 4. For the multi-family buildings built between 1971 and 1980, the energy use is higher than the average value which shows that the Million Programme buildings have poor energy performance.

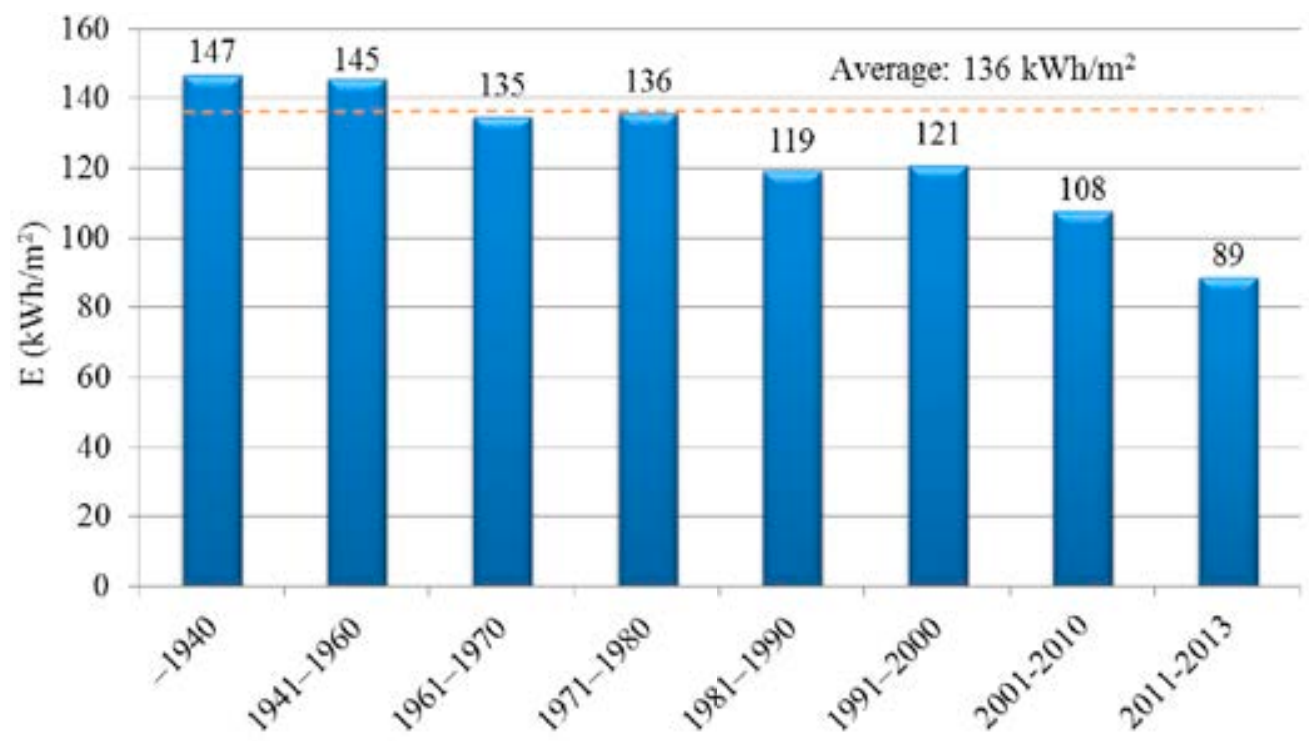

Figure 4: The average energy use in $\mathrm{kWh} / \mathrm{m}^{2}$ during 2015 for heating and domestic hot water by Swedish multi-family buildings distributed by year of construction (SEA, 2016b).

The Million Programme multi-family buildings will be emphasized below, since most of the studied objects in the current studies are multi-family buildings. Five of the studied objects in the appended Paper I and the studied object in Paper II are so-called Million Programme Buildings. Therefore it is necessary to introduce the concept of the Swedish Million Programme. 
During the 1950s and early 1960s, there was an acute housing shortage in Sweden. On April 7, 1965 the Swedish government made a decision to build 100, 000 apartments over 10 years in order to relieve the housing shortage. The buildings constructed during the record-breaking peak period 1965 - 1974 are called Million Programme buildings (Hall \& Vidén, 2005). About 1.5 million people live in those multi-family buildings (Hall \& Vidén, 2005). A third of the units are single-family houses, while the rest are multi-family buildings. Approximately three out of four of these multi-family buildings will require intensive renovations by 2050 .

According to Vidén (2012), by 2012 almost $70 \%$ of all the Million Programme apartment buildings face problems with high energy use and high maintenance cost. In those apartments, the leakage issue which is caused mostly by installation of water and sewage in kitchen and bathroom has to be fixed urgently. In addition, the moisture can also be caused by composite building materials, humid air or ground moisture or moisture released from sources such as cooling machines, washing machines and residents. It is worth mentioning that the reason why the studied object in Paper II was renovated was moisture damage. Furthermore, many ventilation and heating systems are also substandard. The five studied Million Programme buildings in Paper I had problems such as heating systems becoming old and inefficient, cracks in exterior façade, air leakage, and inefficient ventilation system. Therefore the buildings had high energy use and also high $\mathrm{CO}_{2}$ emissions and primary energy use. Both energy efficient and cost optimal measures need to be implemented on those apartments. In order to reduce energy use of buildings, the focus should be placed on insulation of exterior wall, attic floor, exterior floor and window replacement. If the heating system is planned to be changed it is better to do so in combination with insulating the building's envelope (walls, windows, floor and roof) (Vidén, 2012). Therefore having a system overview of the building during renovation will result in financial savings, energy savings and also $\mathrm{CO}_{2}$ reduction (SEA, 2009).

\subsection{The Swedish listed buildings}

The built environment in Sweden has a large number of listed buildings, where $15 \%$ of all apartment buildings and $27 \%$ of all single-family houses were built before 1940 (SCB, 2016). The listed building sector constitutes an important part of the country's built heritage. The Swedish heritage buildings generally have worse energy performance than other buildings, and thus account for a significant part of society's energy use (Broström et al., 2014; Mattsson, 2011).

The Swedish government aims for a $50 \%$ reduction in buildings' energy use by 2050 . In addition to this, the Swedish Building Regulation (BBR) more or less requires the same energy performance for an older building after major renovation as for a new building. According to the BBR, during a renovation for the purpose of energy efficiency the planned measures should not change the building's heritage or culture value in a way that distorts the building from a historical, environmental or aesthetic point of view (Boverket, 2013). According to the Swedish Planning and Building Act (PBL), all the changes to a building should be carried out carefully. Consideration must be taken of a listed building's characteristics and its technical, historical, cultural, environmental and aesthetic values during renovation. It is important to fulfill both the technical and the conservation requirements when renovating a building. In a situation where 
the conservation issue is in conflict with the technical requirement ${ }^{2}$ issue, the conservation requirements of the building should be prioritized (Boverket, 2010b). For example, adding extra insulation to the ceiling or replacing windows and exterior doors are relatively easy to do from a general perspective. However, insulating the façade requires a more nuanced assessment where several factors must be considered. Most buildings with brick facades have existed for decades and have their own character from a particular time period. The character will be lost by adding exterior insulation. Similarly, many concrete facades have characteristics that require special attention, such as special exposed aggregate or decorative patterns. Special sculptural ornamentations on windows, doors and eaves will also be a reason that existing windows and doors with high $U$-values cannot be replaced (Björk, 2012).

The interest in finding a sustainable balance between saving energy and preserving heritage values of listed buildings is increasing. As the pressure for improved energy performance increases, the balance between energy conservation and building conservation must be carefully considered (Broström et al., 2014). Questions such as "What would be the consequences for listed buildings of implementing European and national energy targets?" and "To what extent would policies for building conservation have an effect on the potential for energy savings" are general current issues around listed building stock. According to (Broström et al., 2014), the risks to assessing cultural heritage are stated together with the fact that these considerations may have a considerable impact on the actual potential for improving energy performance. Clearly there is a need for a systematic approach where techno-economic and global environmental considerations can be weighed against the impact on heritage values. Under this context, Papers III, IV and V have shown how to find cost-optimal packages of energy efficiency measures for listed buildings with pre-designed energy target by using the LCC optimization method.

\footnotetext{
${ }^{2}$ Building technical requirement: A building's technical requirements include load capacity, durability, hygiene, health, environment, safety, noise, energy conservation and accessibility, etc. (Boverket, 2010b)
} 


\section{Literature review}

This chapter includes a detailed literature study which includes researches focused on energy efficiency, indoor environment, LCC and environmental impact. This chapter is divided into three parts: renovation of non-listed and listed residential buildings and tools/methods which have been used. There are discussions about the connections between the current studies and the studies included in literature review.

\subsection{Building renovation - non-listed buildings}

The number of publications about renovation of residential building, effectiveness of retrofit on indoor environment and energy performance is currently increasing. Interest in the improvement of energy efficiency in existing buildings, especially in residential buildings that represent $75 \%$ of the European building stock has grown (BPIE, 2011). There are many interesting studies about building renovation of non-listed residential buildings which are similar to the studies included in Paper I and II both in Sweden and worldwide. There are some famous renovation projects of Million Programme multi-family buildings to passive house standard in Sweden: Brogården in Alingsås, Gåredsten in Gothenburg and Katja Road 119 in Gothenburg.

Studies about Brogården can be found in Martinsson et al., 2015a; Sabouri \& Femenías, 2013; Andersson \& Larsson, 2013; Janson, 2008. The buildings at Brogården in Alingsås were built during 1971 and 1973 . The buildings had high energy use and thermal bridges were built in the balconies and facades. The broken bricks were replaced at regular intervals due to vittring. A major renovation was done on the buildings from 2008 to 2013. The energy efficiency of the buildings was improved by replacing the outer walls with new airtight walls in order to avoid heat bridges. District heating is used as heating system for the building before and after the renovation. Domestic hot water (DHW) is produced by renewable fuel which is solar panels (Skanska, 2014; AlingsåsEnergy, 2015; Martinsson et al., 2015b; Karlsson \& Moshfegh, 2014). The ventilation system has been changed from mechanical exhaust air ventilation system to mechanical supply and exhaust ventilation system with heat recovery (MVHR). New balconies were added outside the wall structure. The specific energy use for heating and DHW has been reduced from $177 \mathrm{kWh} / \mathrm{m}^{2} \cdot \mathrm{yr}$ before renovation to $58 \mathrm{kWh} / \mathrm{m}^{2} \cdot \mathrm{yr}$ after renovation. This shows an energy use reduction of $67 \%$. The average indoor temperature was between $22{ }^{\circ} \mathrm{C}$ to $23{ }^{\circ} \mathrm{C}$ after renovation (Martinsson et al., 2015b). However, there is no recorded indoor air temperature of the buildings before the renovation for comparison.

The residential area Gårdsten located north of Gothenburg includes two types of buildings: balcony access buildings and slab buildings. The buildings were built in the early 1970s as part of the Million Programme. The renovation results in solar panels installed on the roofs and on the balconies that provide surplus heat to the city's district heating network. The residents are able to determine the indoor air temperature. However, $21{ }^{\circ} \mathrm{C}$ is included in the rent. If the residents will lower the indoor temperature, the saved money will be refunded. On the other hand, residents have to pay for indoor temperature higher than $21{ }^{\circ} \mathrm{C}$. The renovation cost is $1070 \mathrm{SEK} / \mathrm{m}^{2}$. The specific energy use of the building has been reduced from $263 \mathrm{kWh} / \mathrm{m}^{2}$ before renovation to $145 \mathrm{kWh} / \mathrm{m}^{2}$ after renovation, which indicates that the renovation results in $45 \%$ energy use reduction. 
Katja Street 119 is a four-story building that includes 16 apartments. The building was built in 1971 as part of the Million Programme. The façade of the building was worn and thermal bridges existed in the building's envelope and balconies before the renovation. In addition, air leakages existed between floors and the building had problems with moisture. The energy efficiency measures which have been implemented on the building include the replacement of mechanical exhaust air ventilation system to MVHR, attic floor insulation, crawl space insulation, window replacement, exterior wall insulation from outside and new balconies. The investment in energy efficiency was $3000 \mathrm{SEK} / \mathrm{m}^{2}$. The specific energy use of the building inclusive heating and DHW has been reduced from $178 \mathrm{kWh} / \mathrm{m}^{2} \cdot \mathrm{yr}$ before renovation to 51.9 $\mathrm{kWh} / \mathrm{m}^{2} \cdot \mathrm{yr}$ after renovation. This indicates a $71 \%$ energy use reduction from this major renovation (Martinsson et al., 2015b). However, the indoor environment has not been investigated in this project.

Some other interesting studies on energy efficiency of residential buildings by renovation are e.g.: Thomsen et al. (2016) and Thomsen et al. (2015), who studied energy use and indoor environment of a residential building in Denmark before and after a comprehensive renovation. The renovation resulted in new facades, new windows, additional insulation, mechanical ventilation with heat recovery and a photovoltaic installation on the roof. The measured energy use for heating and DHW before and after renovation were $139.1 \mathrm{kWh} / \mathrm{m}^{2} \cdot \mathrm{yr}$ and 95.6 $\mathrm{kWh} / \mathrm{m}^{2} \cdot \mathrm{yr}$, respectively. The energy use reduction for this case is $31 \%$. In addition, the study also showed an improved indoor climate which was based on the measurements and survey.

The studies included in this thesis show some similarities to the above-mentioned renovation projects. The implemented EEMs which have been used in the current studies (insulation on different building construction parts, solar panel installation, MVHR ventilation system installation, etc.) are similar for the above-mentioned projects. In addition, the renovation costs for the current studies included in Paper I are between $544 \mathrm{SEK} / \mathrm{m}^{2}$ to $2158 \mathrm{SEK} / \mathrm{m}^{2}$. This is in the range of the renovation costs for Gårdsten and Katja Street. The indoor environment has been improved both in the current studies and in most of the above-mentioned projects due to renovation.

\subsection{Building renovation - Listed buildings}

The number of studies of listed buildings is increasing. According to Martinez-Molina et al. (2016) who have done an overview of energy efficiency in historical buildings from 1978 to 2014, most of the studies of listed buildings focus on reusing heritage buildings and propose suitable technical solutions for enhancing energy efficiency while maintaining building heritage values. The current studies in Papers III, IV and V are in line with this. Martinez-Molina et al. (2016) have also stated that most researchers (23\%) analyzed residential buildings. In addition, the rest of the researches are about religious buildings $(17 \%)$, scholars and palaces $(17 \%)$, museums and libraries (11\%), urban areas (10\%) and others (22\%). Italy (followed by Spain, UK and China) is the country that has generated most papers related to the energy efficiency in listed building research, e.g. (Mauro et al., 2015; Bonomo \& De Berardinis, 2014; De Berardinis et al., 2014; Ascione et al., 2013). As the statistic shows in Martinez's research, publications of listed buildings from Sweden are few, e.g. (Rohdin et al., 2012; Broström et al., 2012; Eriksson et al., 2014). The current studies included in Paper III, IV and V are all about 
energy efficiency of the Swedish listed buildings by renovation and have thus provided new material and new methods for the whole research field of listed buildings.

Kohler \& Hassler (2012) state that it is challenging to improve the energy performance of listed buildings while also preserving their heritage value. According to Martinez-Molina et al. (2016) the research on listed urban areas are very recent and were all published during 2011 and 2014. The investigated building groups and towns are from the $20^{\text {th }}, 18^{\text {th }}$ and $13^{\text {th }}$ centuries, and the Italian structures have been studied most. Most of this research has focused on $\mathrm{CO}_{2}$ emission reduction, energy use and finding cost-optimal energy efficient measures.

Mauro et al. (2015) have investigated the cost-optimality of a building category under energy renovation in south Italy. One representative building sample has been chosen and used to consider potential variations in all parameters affecting energy performance. Simulationbased large-scale uncertainty and sensitivity analyses have been done by using Energy Plus and MATLAB. The results show that the cost-optimal retrofit package includes the installation of condensing gas boiler, water-cooled chiller and full-roof photovoltaic system.

A Norwegian study focused on timber-frame buildings in order to illustrate the potential for and problems with energy-efficiency measures (Grytli et al., 2012). Three methods have been combined which are life cycle assessment, energy calculations and a self-developed heritage value assessment system. The combination of the methods makes it possible to discuss optimal solutions for energy improvement, taking both environmental and heritage aspects into consideration.

Fabbri et al., (2012) have based on Energy Performance Certificate (EPC) database of listed buildings in Italy in order to evaluate the energy use of the buildings in a town, to identify energy saving strategies. The analyses also include finding influence of typology factor for energy saving in listed buildings. The results show that studying the statistical analysis of EPCs of entire zones of a city could be a way to support a bottom-up or top-down model or energy statistical data. The results include how it is possible to understand energy performance of existing buildings in order to define heritage requirements and energy efficiency priority.

\subsection{Tools and methods}

\subsubsection{BES}

Kuusk et al. (2016) have studied a typical concrete multi-family building which has been the subject of major renovation in Estonia. Technical measurement and BES (IDA ICE) have been used to study energy use and indoor climate. The implemented EEMs are roof insulation, external wall insulation, window replacement, new balconies, heating system reparation and ventilation system reparation. The measured energy use before and after renovation were 212 $\mathrm{kWh} / \mathrm{m}^{2} \cdot \mathrm{yr}$ and $132 \mathrm{kWh} / \mathrm{m}^{2} \cdot \mathrm{yr}$ which indicates a $38 \%$ energy reduction. The indoor climate has been improved as the $\mathrm{CO}_{2}$ concentration meets indoor climate class II and the indoor temperature becomes stable due to better adjustment of new heating system. The actual renovation costs were $1333 \mathrm{SEK} / \mathrm{m}^{2}$.

Molin et al., 2011 have evaluated the energy performance of a low-energy house based on on-situ measurements and building energy simulation (BES). The built model has been 
validated by comparing the hourly and monthly measured data. The deviation of the energy use provided by BES model and the measured value is $7 \%$. In Diamond, 2011, the comparison between modeled and billed energy use of a group of 18 buildings shows that the mean value of accuracy is $1 \%$. A study of energy demand and indoor climate in a low energy building done by Karlsson \& Moshfegh (2006) shows that the deviation between measured and simulated heat demand is $+5.8 \%$ and the indoor air temperature is $\pm 2{ }^{\circ} \mathrm{C}$. The accuracy of BES models in a large study of 121 buildings shows that the correlations between measured and simulated design consumption ranged between 0.25 and 2.5 (Newsham et al., 2009). According to ANSI/ASHRAE (2004), the accepted validation criteria of BES model is $5 \%$ (monthly) or $10 \%$ (hourly). The internal heat gains are in special focus since they have major impact on energy use.

In the appended Papers I and II several methods have been combined and used in order to investigate the energy use and to analyze the indoor environment of the studied buildings. The combined methods include on-site measurements, BES and standardized indoor environment questionnaire. This approach is unique in comparison with the above mentioned literature studies. In the appended Papers I and II, the deviations of the annual specific energy use between the measured and simulated values of the corresponding model are less than $2 \%$, which indicates the built BES models are in good agreement with reality.

\subsubsection{Parametric study}

Sensitivity analysis plays an important role in building energy analyses to support model predictions (Braulio-Gonzalo et al., 2016). It can be used to identify the key variables affecting building thermal performance from both energy simulation models and observational study (Tian, 2013). There is a great need of detailed understanding of the relationships between the uncertainties of an energy model in order to improve the model's robustness and accuracy (Kavgic et al., 2013a). The literature review shows that many sophisticated sensitivity analysis techniques have been developed and implemented for building energy simulation. One method called local sensitivity analysis has been used in the current study. By using this method only one parameter is changed at a time while other inputs are kept constant. This method is the simplest and a very useful method used in the field of building energy analysis (Tian, 2013). This method has also been used e.g. by (Kavgic et al., 2013b), (Hemsath et al., 2015) (Samuelson et al., 2016) and (Konstantinou \& Knaack, 2013) and (Petersen \& Svendsen, 2010).

The sensitivity analysis in the current study investigates only the variations in the model output while small changes in model input parameters are changed. Several parametric studies (e.g. adding external blinds on the windows, varying discount rate and energy price) have been applied in order to analyze how the changed parameter will influence the building's indoor environment, energy use, LCC and EEM package, see appended Papers II and IV.

\subsubsection{LCC}

LCC is a type of investment tool used to rank different investment alternatives. LCC approach has an expanded life cycle perspective. It takes consideration of both the investment cost and running cost during the installed product's life time (Gluch \& Baumann, 2004). The early studies using LCC for building investment were done by Bennett \& Norman (1987). Gustafsson (1988) developed a software using the LCC method in order to find the cost- 
optimal energy efficiency renovation strategy of residential buildings. This program has been further developed by using mixed integer linear programming (Gustafsson, 1998a; Gustafsson, 1998b). The program has been used for investigating the most cost optimal energy-efficiency measures for multi-family buildings (Gustafsson, 1990; Gustafsson, 1998a; Gustafsson, 2000; Gustafsson, 2001).

LCC method has been used in several recent research projects for calculating the total cost of a building during its whole life time. (Jeong et al. 2017) have developed a prediction model for calculating cost saving potentials by using LCC analysis. Marszal \& Heiselberg, 2011 have compared the total life cycle cost and net savings of a Net Zero Energy Building by implementing different measures and using different district heating systems. Bonakdar et al., (2014) have done cost optimal analysis of fabric renovation in a Swedish multi-story residential building. They have calculated the marginal difference between the energy cost by using space heating and the implementing cost of the suggested EEMs.

Niemelä et al., (2017) have studied the energy performance and cost effectiveness due to major renovation of a typical brick apartment building located in Finland. BES and LCC optimization have been combined in this study. Parametric studies have been done in order to test different combination of EEMs which in turn results in different energy savings and LCC. The results show that ground water heat pump seems to be the global cost-optimal main heating system concept. Exterior wall insulation seems to be a reasonable and cost-effective option only at the higher energy performance target levels, when other more cost-effective options have already been used. The solar thermal system proved to be a cost-effective alternative to be used with district heating system. In addition, the results also show the importance of the interest rate used in the economic calculations. A high interest rate results in lower investment cost. Wang \& Holmberg (2014) have developed an approach to assess energy-demand retrofitting scenarios by analysing four types of typical Swedish residential buildings. The methods used are energy-demand simulation and life-cycle cost analysis (LCCA). The results from the current research indicate the long-term energy savings and economic profits and will contribute to the standardization of future retrofitting designs on the municipality scale in Sweden.

\subsubsection{Bottom-up and building categorization}

In the appended Paper V, a bottom-up approach has been used. Swan \& Ugursal (2009) have reviewed various modeling techniques used for modeling residential sector energy consumption. Two approaches are identified, which are top-down or bottom-up.

The top-down approach treats the residential sector as an energy sink and does not distinguish energy use due to individual end-uses. The Top-down model determines the effect on energy use, primarily for the purpose of determining supply requirements. It will give an overview of the total energy use of the whole building stock. By using this model, only aggregated data such as macroeconomic indicators, climatic conditions, housing construction/demolition rates, and estimates of appliance ownership and number of units in the residential sector are needed. However it is lack of identifying the energy use of individual enduses which will eliminate the capability of identifying key areas for improvements for the reduction of energy use (Swan \& Ugursal, 2009). 
By using the bottom-up model, the required data are highly representative samples that can be extrapolated to represent a larger stock (Aksoezen et al., 2015a). The model can account for the energy use by individual buildings or categories. The result can then be extrapolated to represent a higher level such as regional or national level. Common input data to bottom-up models include dwelling properties such as geometry, envelope fabric, equipment and appliances, climate properties, as well as indoor air temperatures, occupancy schedules and equipment use. This high level of detail is a strength of bottom-up modelling and gives it the ability to model technological options (Swan \& Ugursal, 2009). The method has been used in many researches related to energy efficiency analysis of building stock.

Wang \& Holmberg (2014) have presented an approach to design and assess energy-demand retrofitting scenarios. They categorized the existing Swedish building stock into four groups with representative archetype for each group. The results include cost-effectiveness and energysaving potentials of the archetypes have been extrapolated by the numbers of present archetypes to city or national level. Comparisons of energy demand and cost-effectiveness have been done between the four categories by implementing two different renovation alternatives. The model indicates that the energy saving potential of retrofitting is $36-54 \%$ in the archetypes. However, retrofits with the largest energy-saving potential are not always the most cost effective. The long-term profits of retrofitting are largely dominated by the building types.

Mata et al. (2013) have presented a bottom-up model of assessing energy-saving measures and $\mathrm{CO}_{2}$ mitigation strategies for the building sectors. The results show that the maximum energy use reduction potential of the studied building sector is $53 \%$, corresponding to a $63 \%$ reduction in $\mathrm{CO}_{2}$ emissions. The results also show that although application of the investigated EEMs would reduce $\mathrm{CO}_{2}$ emissions, the measures that reduce electricity consumption for lighting and appliances will increase $\mathrm{CO}_{2}$ emissions, since the saved electricity production is less $\mathrm{CO}_{2}$-intensive than the fuel mix used for the increased space heating required to make up for the loss in indirect heating obtained from lighting and appliances.

Balaras et al. (2007) evaluated the energy conservation measures (ECMs) for the residential building stock in EU and their effect on reducing the environmental impact of $\mathrm{CO}_{2}$ emission. The authors have classified the residential building stock into three building categories based on buildings' construction periods: pre-1980, 1980 - 2001 and 2001 - 2010. Different energy conservation scenarios and their impact on the reduction of $\mathrm{CO}_{2}$ emissions were evaluated. Accordingly, the most effective ECMs are the insulation of external walls $(33-60 \%$ energy savings), weather proofing of openings $(16-21 \%)$, the installation of double-glazed windows $(14-20 \%)$, the regular maintenance of central heating boilers $(10-12 \%)$, and the installation of solar collectors for sanitary hot water production $(50-80 \%)$.

Uihlein \& Eder, (2010) used the EU-27 building model that represents the development of the building stock of each of the EU-27 countries for six different building types from 1900 to 2060 to calculate the energy demand due to space heating. Huang \& Berkeley (2000) have developed a model to evaluate space heating and cooling loads of the American building stock based on 16 multi-family and 46 single-family typical residential buildings. The typical buildings were simulated in 16 different regions and the results were up-scaled to a national level. Shimoda et al. (2004) have used 20 building types and 23 household types to represent 
the variety of houses within the city of Osaka, Japan. A residential end-use energy use model on the city scale has been built. Swan and Ugursal stated that there is a clear development of bottom-up model usage with a variety of techniques.

However, the concept of a bottom-up methodology which includes a combination of categorization and a LCC optimization method in order to find the cost-optimal solutions while having constraints in order to preserve the buildings' heritage value makes the current study unique. 


\section{Building as an energy system}

This chapter describes the different system boundaries which have been studied during my study. The chapter also describes the energy balance in a building and the parameters which are able to affect a building's energy use. The importance of indoor climate is described in the following section.

A building as an energy system consists of technical systems, residents and organizations (Karlsson, 2006). The technical system includes, for example, windows, the building envelope, the ventilation system and household appliances. Occupants' activities have great impact on a building's energy demand. The organization for a multi-family building could be the property manager/owner or a combination between the occupants and the property manager. A building's indoor temperature depends on the relationship between the heat which is transported into the building and the heat loss from the building. Parameters which can impact the building's heat balance and indoor climate will be presented.

\subsection{The system boundary}

If the system boundaries are vague or ill-defined, it is difficult to carry out an analysis founded on indisputable facts (Abel \& Elmroth, 2007). Therefore it is necessary to select system boundary in order to assess the energy use of a building or a group of buildings. Figure 5 shows the energy system boundaries used in this thesis. The analysis done in Paper I and II are within boundaries A, B, C, D and E. The analysis in Paper III, IV and V are within energy boundaries $\mathrm{E}$ and $\mathrm{F}$.

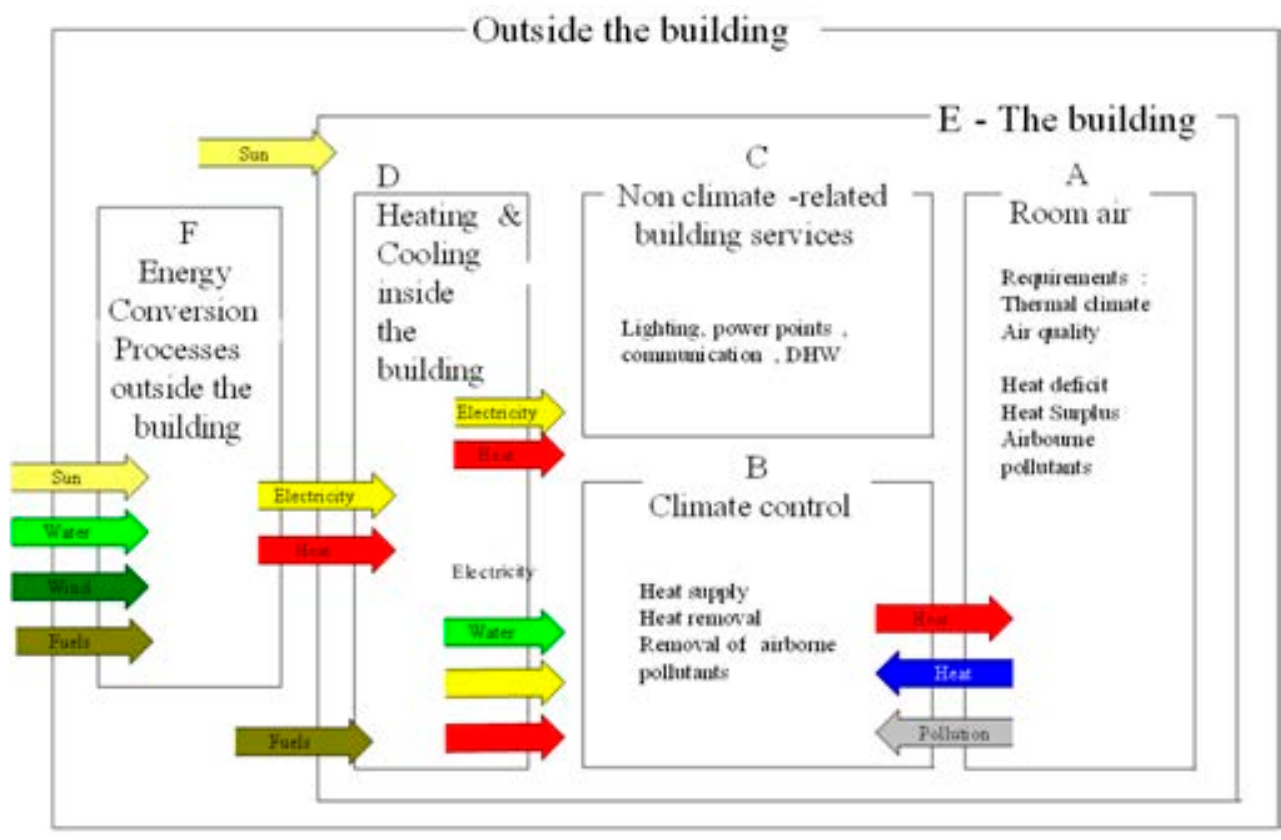

Figure 5: The system boundaries used during the current research. Inspired by: Abel \& Elmroth (2007) Buildings and Energy - a systematic approach. 
A: Room air. The system boundary is drawn around a room which is limited by the room's air, walls, floor and ceiling. The energy system on this level includes indoor climate, residents, household equipment and HVAC system to remove large heat and pollutant surpluses. The system includes hot water use, sewage, household electricity use, etc. The room temperature is influenced by the emitted heat from the residents and the warm surfaces in the room as well as the convective heat exchange between the walls, floor and ceiling and the room air and longwave radiation exchange between surfaces. The analysis was done at room level and includes: measurements of indoor temperature, air flow and indoor climate. These measurement techniques are presented in Section 6.1.

B: Climate control. This energy system boundary includes all installed equipment which will carry out the tasks such as heat supply, heat removal, and airborne pollutant removal. The system can include an advanced HVAC plant designed to remove large heat and pollutant surpluses. It can also include a window which is opened to remove the surplus heat and pollutant.

C: No climate-related building services. The system comprises all the services that are not related to the state of the outdoor climate, e.g. lighting, computers, telephones, sewage disposal, DHW etc. The users are not included in this system.

D: Heating and cooling inside the building. The system includes energy provided by boilers and heat pumps, and other heat sources, solar collectors, coolers, etc. are considered included in this energy system.

E: Building level. The boundary lies on the building's envelope which includes external walls, external floor and external roof. The system limit is on the outside of the envelope. The energy system on building level includes all the systems A, B, C and D. Analysis which has been done on building level has been carried out by using building energy simulation (BES) method and life cycle cost (LCC) optimization method. Detailed description of BES and LCC optimization can be found in section 6.2 and 6.3. The outputs from analysis of the energy system on building level includes: the energy use of building, LCC, EEM package, $\mathrm{CO}_{2}$ emissions and primary energy use etc.

F: Energy conversion process outside the building. When the total energy balance of a building is studied, all flows of energy through the system boundary, including solar energy and heat losses, must be taken into account (Abel \& Elmroth, 2007). The energy supply to the building from electricity grids and district heating systems are included in this energy system. In addition, management and maintenance of the building are also included.

\subsection{Energy balance in a building}

A building's indoor temperature depends on the relationship between the heat which is supplied to the building and heat loss from the building as well as heat that is stored in the thermal mass of the building. The supplied heat comes not only from the external heat source such as district heating and heat pump, but also from solar irradiation and internal heat generation which consists of heat generated from residents and by household electricity appliances or other processes that generate heat. The heat losses are influenced by transmission, 
ventilation and infiltration. When the heat balance between the supplied energy and the energy losses achieved, the building's temperature will be stabilized.

A building's energy balance over a longer time period (thus making the influence of the thermal mass negligible) can be described by the following equations (Abel \& Elmroth, 2007; Warfvinge \& Dahlblom, 2012):

$E_{\text {Supply }}=E_{\text {Heat loss }}$

Equation 4.1

$E_{\text {Supply }}=E_{\text {purchased }}+E_{\text {internal heat }}+E_{\text {solar }}$

Equation 4.2

$E_{\text {Heat loss }}=E_{\text {Tansmission }}+E_{\text {Ventilation }}+E_{\text {Infiltration }}$

Equation 4.3

$Q_{\text {tot }}=\Sigma U_{j} \cdot A_{j}+q_{\text {vent }} \cdot \rho \cdot C_{p} \cdot(1-\eta)+q_{\text {infil }} \cdot \rho \cdot C_{p}$

Equation 4.4

$E_{\text {Heat loss }}=Q_{\text {tot }} \cdot G_{t}$

Equation 4.5

$P=Q_{\text {tot }} \cdot\left(T_{\text {in }}-T_{\text {out }}\right)-\left(P_{\text {internal heat }}+P_{\text {solar }}\right)$

Equation 4.6

$T_{\text {balance }}=T_{\text {in }}-\frac{\text { Pinternal }+ \text { Psolar }}{\text { Qtot }}$

Equation 4.7

Where $Q_{\text {tot }}$ is the total specific heat loss of a building $(\mathrm{W} / \mathrm{K}), U_{j}$ is thermal transmittance of the respective building elements $\left(\mathrm{W} /\left(\mathrm{m}^{2} \cdot \mathrm{K}\right)\right)$ including thermal bridges; $A_{j}\left(\mathrm{~m}^{2}\right)$ is area of the respective building elements; $\rho\left(\mathrm{kg} /\left(\mathrm{m}^{3}\right)\right.$ is air density; $C_{p}(\mathrm{~J} /(\mathrm{kg} \cdot \mathrm{K})$ is the specific heat capacity of air; $G_{t}\left({ }^{\circ} \mathrm{C} \cdot \mathrm{h}\right)$ is degree hours; $\eta(-)$ is the efficiency of the ventilation systems heat recovery unit; $q_{v e n t}$ is the air flow $\left(\mathrm{m}^{3} / \mathrm{s}\right) ; q_{\text {infil }}$ is the flow of infiltration $\left(\mathrm{m}^{3} / \mathrm{s}\right) ; P$ is the building's power demand $(\mathrm{W}) ; T_{\text {in }}$ and $T_{\text {out }}$ is indoor and outdoor temperature $\left({ }^{\circ} \mathrm{C}\right) ; T_{\text {balance }}\left({ }^{\circ} \mathrm{C}\right)$ is the corresponding outdoor temperature at which a heating requirement arises, thus a heating system has to operate for lower outdoor temperatures. $T_{\text {balance }}\left({ }^{\circ} \mathrm{C}\right)$ affects the building's heating elements which will be shut down before the pre-determined indoor temperature is reached. The internal heat generation and solar energy will cover the energy that is needed for outdoor temperatures higher than $T_{\text {balance, }}$, so that the indoor temperature will be at least $T_{\text {in }}$ (indoor set point temperature).

However, when simulating shorter time intervals, processes are more complex since dynamics have to be considered. IDA Indoor Climate and Energy (IDA ICE) is thus a proper tool which can be used. IDA ICE is a dynamic multi-zone simulation application for the accurate study of the thermal indoor climate of individual zones as well as the energy use of an entire building (Equa Simulation, 2009).

\subsubsection{Ventilation system}

The ventilation system plays an important role in providing and maintaining optimal air quality and thermal comfort in buildings. The energy requirement for ventilation can be reduced considerably by improving the efficiency of the ventilation system with heat recovery from return air. In Sweden, according to the BBR the air velocity in an occupied zone in a room should not exceed $0.15 \mathrm{~m} / \mathrm{s}$ during the heating season and the air speed in the zone from the ventilation system should not exceed $0.25 \mathrm{~m} / \mathrm{s}$ during the rest of the year. Moreover, the lowest air change rate should be $0.35 \mathrm{l} / \mathrm{s}$ per $\mathrm{m}^{2}$ floor area (Boverket, 2016).

Today, there are several ventilation systems used in buildings in Sweden, such as natural air ventilation system, mechanical exhaust air ventilation system and mechanical supply and 
exhaust ventilation system with heat recovery (MVHR). In a natural air ventilation system, the warm indoor air rises and escapes through the air passages and creating a negative pressure in the building. The greater the temperature difference is between outdoor and indoor air, the larger the air flow entering the building will be. In summer, when the temperature difference is small, the ventilation performance will be low. Furthermore the effect of wind that creates a negative pressure in the building is also a driving source for natural ventilation. In a mechanical exhaust air ventilation system, the air is sucked out of the building by fans from kitchen, toilets and bathrooms. The advantage with a mechanical exhaust air ventilation system is that the exhaust fan is always running and ensures air circulation in the house. The disadvantage with this kind of air ventilation system is that it uses electricity and sometimes emits excessive noise from the fans. Moreover, the inlet air will be cold during winter (SEA, 2016a).

The advantage with an MVHR system is that system ensures that the supply air temperature is very close to room temperature. The households will get new, fresh air and a very comfortable indoor environment, with minimal risk of cold drafts. A MVHR system recovers $50 \%$ to $80 \%$ of the supplied heat needed to increase the outdoor air temperature to indoor temperature. Another important parameter is that ventilation is separate from the heating system (radiators) which means that the household can freely choose the heat source (Swedish Ventilation, 2015).

In Sweden, the National Board of Housing sets mandatory requirements and provides general advice regarding new and renovated buildings. The National Board of Housing also sets mandatory ventilation inspection $(\mathrm{OVK})$. The mandatory ventilation inspection was introduced in 1992 and should be performed every three or six years, depending on the type of ventilation system. An approved OVK inspection shows that the building's ventilation system still works well.

\subsubsection{Households' impacts on building's energy use}

Households can influence the use of heat to a great extent in their living quarters, for example by not opening the windows or by regulating the indoor temperature. However, they cannot decide the airtightness, insulation thickness of external walls or the window's performance which are the important parameters for overall energy use in a building. Lindén et al., (2009) mention that the costs for heating and domestic hot water are usually included in the monthly cost of accommodation, households themselves only pay for their electricity use. The households thus have little incentive to reduce the use of heat in comparison with the use of electricity.

Households ventilate their apartments often by opening the windows when it feels too warm inside instead of regulating the temperature indoors. It is difficult for many households to regulate the radiators since the heat which is supplied to them is often controlled centrally even if they can locally regulate the radiators via thermostats. It means that households are still limited in their ability to control indoor temperature. Generally, the indoor temperature is higher in apartments than in single-family houses. This can be partly explained by the fact that apartment households are not aware of their heating costs as they do not pay them directly (Lindén, 2009). Lindén (2009) also states that it is important not only focus on individual 
households but also to focus on housing companies and property owners when designing policy instruments to improve energy efficiency in households.

The indoor temperature is also affected by the heat emitted by household's electric appliances. Karresand et al., (2009) show in their study that households from low-energy houses use the heat emitted from electrical appliances to keep it warm inside. Sveby, (2012) recommends an average value of internal heat which is $80 \mathrm{~W}$ per person and attendance time of 14 hours per day. According to Sveby, percentage of household electricity which will contribute as useful heat is $70 \%$. A standard value of useful heat from household electricity is $30 \mathrm{kWh} / \mathrm{m}^{2}$ heated area.

\subsection{Indoor Climate}

Indoor climate is a general term which can be used in different contexts. In this thesis "indoor climate" is defined as the environment in which the residents live with respect to the factors that are affected by the technical installations. However, different people experience the same climate in different ways. Variations are due to issues such as clothing, activity, age and gender. The physical parameters that influence the quality of the indoor environment are 'sound'; 'light'; 'indoor air quality' and 'thermal climate' (Ekberg, 2003). These parameters are also used by the Swedish Social Board to measure the indoor climate of a building (Johansson \& Hammerskog, 2005).

According to BBR 20 (Boverket, 2013) buildings and their installations should be designed so that sound from installations, adjoining rooms and outside is dampened. If there is noisy activity outside the building, particular sound insulation measures should be taken. BBR's requirement on the maximum permitted total sound level from all installation functions in a building is $50 \mathrm{~dB}$ (Boverket, 2013). According to R1 (Riktlinjer för specifikation av inneklimatkrav), a good indoor climate should have good access to daylight. Lighting should be arranged to support a good indoor light environment. The shape and shadows should be well designed in a way that diffuse and direct light are appropriately distributed (Johansson \& Hammerskog, 2005).

Thermal climate is more complicated than just air temperature alone. It also includes surrounding surface radiant temperature, air velocity and turbulence intensity and water vapor pressure. These parameters describe a person's thermal environment. Moreover, metabolic rate of the human body and thermal resistance of clothing also play a key role in influencing the thermal susceptibility of a person (Ekberg, 2003). Thermal comfort describes how people experience the indoor climate. The American Society of Heating, Refrigerating and AirConditioning Engineers (ASHRAE) defined "thermal comfort" as "the condition of the mind in which satisfaction is expressed with personal differences in mood, culture and other individual, organizational and social factors" (ANSI/ASHRAE, 2004).

Thermal sensations are different among people even in the same environment. Djongyang et al., (2010) stated that when a group of people stay in very similar spaces, subject to the same climate and belonging to a common culture, they can still have very different opinions on thermal comfort due to the combination of a large number of factors that affect human perception. It has been also mentioned that a number of parameters can affect people's thermal 
comfort: body temperature, skin moisture, physiological effort of regulation, clothing, activity, posture or location, or opening a window (Djongyang et al., 2010).

In order to describe human thermal conditions in a quantitative way, Fanger and his coworkers developed the heat balance equation for another model which is called the "PMV-PPD" model. PMV stands for "Predicted Mean Vote" and PPD stands for "Predicted Percentage of Dissatisfied". Fanger's PMV-PPD model is widely used and accepted for designing and conducting field assessment of thermal comfort (Djongyang et al., 2010). The PMV-index includes seven scales from +3 to -3 ranging from hot, warm, slightly warm, neutral, slightly cool, cool and cold. The index is used to indicate a large group of people's reaction to the thermal climate (ISO 7730, 2005).

According to Fanger's PMV-PPD model, when PMV is equal to 0 this indicates a neutral thermal climate, and PPD equal to $5 \%$ indicates that $5 \%$ of people are not satisfied with the thermal climate. The model also shows that when PMV is between +0.5 or -0.5 this corresponds to a PPD which is $10 \%$. When PMV is equal to +1 or -1 , PPD corresponds to $27 \%$. According to ISO 7730 (ISO 7730, 2005), an acceptable indoor climate is when PMV is between +0.5 and -0.5 which corresponds to PPD below $10 \%$. Fanger (2006) mentioned that to decrease the number of dissatisfied from $20 \%$ to $1 \%$, ventilation rate should be increased enormously which will result in great cost and high energy use.

Thermal comfort can be assessed by the Swedish Standards Institute. The indoor environment is divided into different levels such as "Best", "Good", "Acceptable" and "Unacceptable" according to Swedish standards (SIS, 2007). The indoor environment is considered "Best" when PPD is less than $6 \%$ and PMV is between \pm 0.2 . The indoor environment is considered "Good" when PPD is less than $10 \%$ and PMV is between \pm 0.5 . The indoor environment is considered "Acceptable" when PPD is less than $15 \%$ and PMV is between \pm 0.7 and the indoor environment is considered "Unacceptable" when PPD is larger than $15 \%$ and PMV is less than -0.7 or greater than +0.7 (SIS, 2007).

BBR's requirement on the lowest operative temperature in an occupied zone is $18{ }^{\circ} \mathrm{C}$ in a residential building. The surface temperature on the floor of the occupied zone should not be less than $16^{\circ} \mathrm{C}$ and higher than $26^{\circ} \mathrm{C}$ (Boverket, 2016).

\subsection{Energy efficiency measures (EEMs) of buildings}

“Gripen” is Boverket's (Swedish National Board of Housing Building and Planning) data base for energy performance certificate (EPC) of all buildings in Sweden (Boverket, 2009). This data base has collected all the information from the energy performance-certified (EPC) buildings in Sweden. The "Gripen" database has been used in the project "Climate neutral and Competitive Gävleborg region 2050". According to the Swedish Parliament (Swedish Parliament, 2006), multi-family and commercial buildings should have been energy declared between 2008 and 2009. The statistics provided by the National Housing Board divide the buildings into the following intervals based on the buildings' construction years: before 1940; 1941-1950; 1951-1960; 1961-1970; 1971-1980; 1981-1990; 1991-2000; 2001-2010; 2011 present. The statistics also contain data about heating area, building heating system, building energy use and also the proposed energy efficiency measures, etc. The "Gripen" database 
divides the suggested energy conservation measures (EEMs) into three categories: Control and Regulation; Building Service Technology; and Construction Technology. The saved energy form can also be identified in the new version of this data base. In Table 2 below some examples of different EEMs will be shown and discussed.

Table 2: Some examples of EEMs related to building's heating system and the corresponding saved energy forms.

\begin{tabular}{|c|c|c|}
\hline EEMs - Control and Regulation & Saved energy form & Used in Paper \\
\hline Install new radiator thermostat & Heat & $\mathrm{I}$ \\
\hline Adjustment of heating system & Heat & I \\
\hline Adjustment of ventilation system & Heat/Electricity & II \\
\hline Lower indoor air temperature & Heat & I, II \\
\hline \multicolumn{3}{|l|}{ EEMs - Building service Technology } \\
\hline Energy-saving light bulbs & Electricity & I \\
\hline Installation of energy-efficient ventilation system & Heat & I \\
\hline Heat exchange from exhaust air & Heat & $\mathrm{I}$ \\
\hline \multicolumn{3}{|l|}{ EEMs - Construction technology } \\
\hline External wall insulation & Heat/Electricity & I, II, III, IV and V \\
\hline Attic floor insulation & Heat/Electricity & I, II, III, IV and V \\
\hline External floor insulation & Heat/Electricity & I, II, III, IV and V \\
\hline Installation of energy-efficient windows & Heat/Electricity & I, II, III, IV and V \\
\hline Weather-stripping on windows, doors & Heat/Electricity & I, II, III, IV and V \\
\hline
\end{tabular}

Old thermostats on water-based radiators are often not temperature-controlled at all. The hot water flows freely through the radiator as soon as the resident switches on the thermostat. On the contrary, modern thermostats regulate the hot water supply to the radiator based on the ambient temperature which saves energy in an efficient way. When the preset indoor temperature is reached, the hot water flow is throttled automatically. This also increases the difference between the temperature of the supply and return flow in the radiator significantly. It gives a much better heat output than if the water mixed freely in the radiator. In this way a temperature-controlled thermostat is both energy-efficient and economic-efficient (The builder, 2015).

Adjustment of the heating system will provide a smooth and balanced indoor temperature and will also save energy for heating in the whole building. There are two ways of adjusting the heating system: "low-flow method" - (adjustment of low flow and high supply temperature); "High-flow method" - (adjustment of high flow and low supply temperature). The Low-flow method is a way of balancing a heating system with a very low flow so that the pressure losses in the distribution pipes are negligible. High-flow method is the conventional initial adjustment method which is used for designing the radiator system. It involves a supply temperature of $55{ }^{\circ} \mathrm{C}$ and a return temperature of $45^{\circ} \mathrm{C}$. This method allows the system to be compatible with other heat sources which often heat the system up to $60{ }^{\circ} \mathrm{C}$ (Alsmyr, 2014; Petersson \& Werner, 2003). 
Liu et. al (2015) (Liu et al., 2015) have showed that by decreasing the studied building's indoor temperature by $1{ }^{\circ} \mathrm{C}$ will result in a reduction in space heating demand by $9.5 \%$ during the whole year. But this measure has shown to increase the PPD value.

A well-adjusted ventilation system is an important prerequisite for efficient energy use in buildings. The mandatory ventilation inspection (OVK) should be performed every three or six years, depending on the type of ventilation system. A correctly adjusted ventilation system reduces the risk of poor indoor air quality, noise, moisture and radon problems. Consequence of an unadjusted ventilation system is for example high supply air flow which will cause overpressure in the building, which in turn will cause moisture and mold problems (Johansson \& Hammerskog, 2005).

According to the Swedish Energy Agency, approximately $14 \mathrm{TWh}$ electricity is used for lighting in Sweden every year. According to the Swedish lighting industry, the total annual electricity use for lighting by households is about 3.6 TWh and the saving potential is about 1.7 TWh (Lightning Industry, 2013). For a traditional light bulb, the energy use is between 15-20 $\mathrm{kWh} / \mathrm{yr}$ in comparison with a light emitting diode (LED) lamp which only uses about 10-11 $\mathrm{kWh} / \mathrm{yr}$. Moreover, LED lamps are efficient, unbreakable and have long life time high switch speed (SEA, 2017b).

Oil is the most expensive heat resource and a finite fossil fuel, while it also emits as much as $300 \mathrm{~kg} \mathrm{CO}$ by using $1 \mathrm{MWh}$ oil (Gode et al., 2011). Today there are still some buildings in Sweden using oil as a heat source (see Figure 2). This form of energy should be replaced by other sustainable energy forms. Using electricity produced by fossil fuels for heating buildings is not either an efficient way from an energy perspective. This energy form has high cost and also high primary energy factor and $\mathrm{CO}_{2}$ emission factor. As mentioned in Section 2.1, district heating is the dominant energy form for heating for multi-family buildings and commercial premises. District heating is also a convenient heating option for many single-family buildings since they will avoid problems such as soot, maintenance of heat pumps and wood boilers, buying fuel, etc. Moreover, this energy form will also facilitate common system solutions. The Swedish district heating production comprises almost $90 \%$ biofuels which in turn has reduced dependence on oil and $\mathrm{CO}_{2}$ emissions (SEA, 2017a). This energy source means high investment cost but low running cost, in comparison with heat pump installation which has low investment cost but high running cost.

Exterior wall insulation from outside or inside can highly increase the energy efficiency of the building's. This has also been proved by Zagorskas, De Berardinis and Milic (De Berardinis et al., 2014; Milic, 2016; Zagorskas et al., 2014). In addition, measures which can improve building's energy use also include optimization of the performance of the building's envelope and intelligent operation and management of HVAC (Heating, Ventilation and Air Conditioning) system, replacing old door and windows with energy-efficient ones and improving the building's air tightness, etc. (Aste et al., 2012; Broström et al., 2014; Jung et al., 2013; Liu et al., 2014; Xu et al., 2012).

In the current study, the interior insulation of the external walls is not considered to be a viable choice and is thus not included. One reason is to avoid condensation problems in the 
wall which in turn will lead to moisture and mould problems. Other reason is to avoid reduction of the living area. Insulation of exterior wall from inside will risk the outer wall becoming too cold and not being able to evaporate accumulated moisture. Another risk is the pores of wall material will be closed which will prevent moisture move out. In addition, the disadvantage of not seeing the original materials from the inside and complexity of the installation have also been mentioned by Zagorskas et al., (2014).

In the appended Papers III, IV and V, the attic floor insulation is assumed to be done by blowing loose fill (e.g. cellulose, mineral wool) in to the attic floor to the desired depth. Another way is by using fiberglass which is packaged in rolls with standard widths but various thicknesses. The batt should be placed between joists or studs in the framing and one or more layers are needed in order to achieve the desired level of insulation.

The energy-efficiency windows which have been mentioned in the appended papers include 2+1 window, 3 glazing with low emissivity coating, and 3 glazing with low emissivity coating and gas between panes. By installing a sealed glazed unit to the inner glass of the current 2 glazing window, the $U$-value of the window will be reduced from about $2.9 \mathrm{~W} /\left(\mathrm{m}^{2} \cdot{ }^{\circ} \mathrm{C}\right)$ to 1.6 $\mathrm{W} /\left(\mathrm{m}^{2} \cdot{ }^{\circ} \mathrm{C}\right)$. This will retain a building's character as much as possible which is considered one of the acceptable EEM for listed buildings. Low emissivity coating will minimize the amount of short-wave infrared light without affecting the visible light. Low-e coating will reduce the emissivity of the window glass surface and will also improve the windows performance and insulating property (PPG Glass Education Center, 2016). The used $U$-value of a 3-glazed window with low e-coating is assumed to be $1.1 \mathrm{~W} /\left(\mathrm{m}^{2} \cdot{ }^{\circ} \mathrm{C}\right)$ in the appended papers. The used $U$-value of a 3 glazed window with low e-coating and gas inside is assumed to be $0.8 \mathrm{~W} /\left(\mathrm{m}^{2} \cdot{ }^{\circ} \mathrm{C}\right)$ in the appended papers. Since the installation of the last two window types will affect the building's appearance, they are not considered proper measures for listed buildings. 


\section{Methodology}

This chapter includes a detailed description of the methodology developed during the current study.

To achieve a systematic and holistic study of energy efficiency questions about buildings, the methodology which has been developed in the current research is based on a bottom-up approach and consists of three different study levels: building level, cluster level and district level. Different analyses have been done on different study levels using different tools. Figure 6 illustrates this developed methodology. Studies included in the appended Papers I, II, III and IV are case studies on the building level, while the appended Paper V is on the cluster level and district level. Detailed description of the methods/tools used will be found in the following sections. There are different stakeholders who are interested in results from different study levels as also shown in Figure 6. By using the methodology, the referenced RQ 1 can be answered on building level; RQ 2 \& RQ 3 can be answered on both building level, cluster level and district level. RQ 4 can be answered on cluster level and district level.

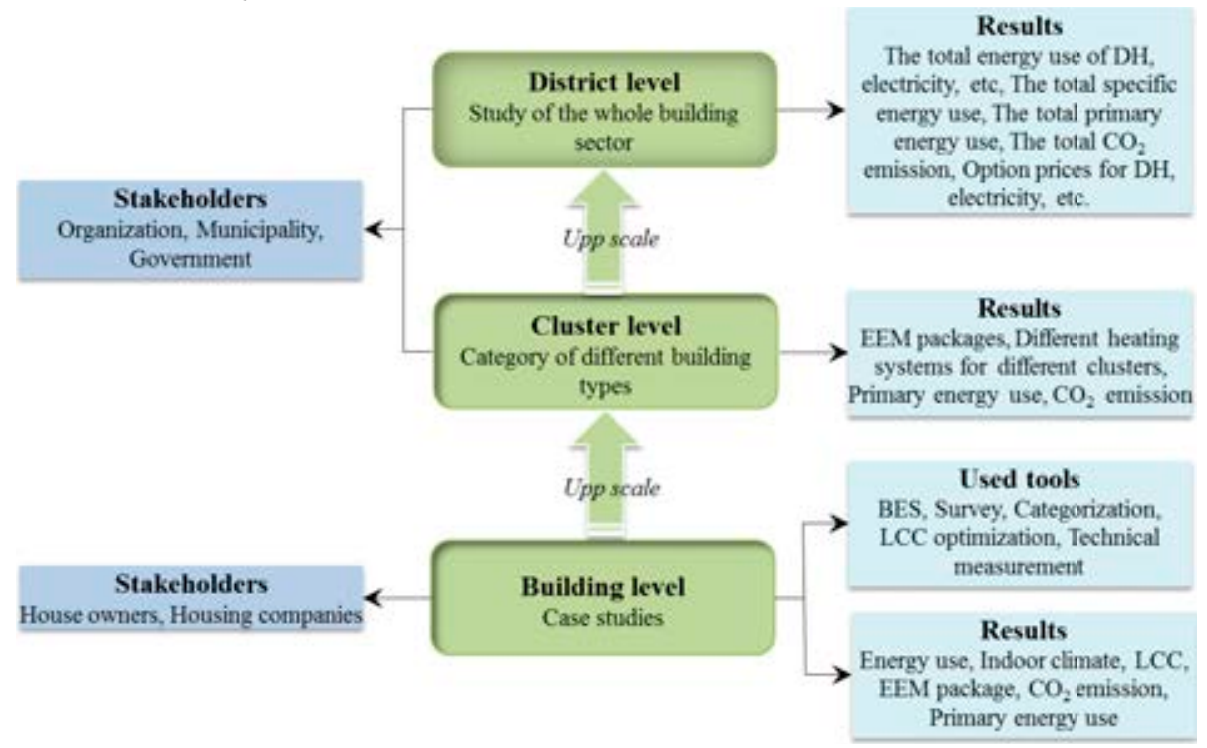

Figure 6: Illustration of the methodology developed during the current study.

\subsection{Building-level-case study}

Studies included in the appended Papers I, II, III \& IV are case studies which are done on building level. Case study research is particularly advantageous when "how" or "why" questions are asked about a current set of events over which the researcher has little or no control. The method is particularly beneficial when studying a complex phenomenon involving one or both of these two questions (Yin, 2009). According to Lekvall \& Wahlbin (2007), case studies are studies where the interest is in a detailed and explorative analysis of single cases. If the studied system or case is complex but does not involve the aforementioned questions, or if the study involves a lower degree of complexity, other methods may be more advantageous. When designing a case study one of the important issues is how to evaluate the result which according to Yin (2009) can be done in the following ways: constructive validity, internal 
validity, external validity and reliability. Constructive validity means establishing accurate operational measures for the concepts studied. Internal validity (which only concerns explanatory or causal studies) refers to establishing a causal relationship, where certain conditions are shown to be correlated to other conditions, as distinguished from false relationships. External validity denotes outlining the system boundaries to which the research findings can be generalized. Reliability means that the operations of a study may be repeated with the same results (Yin, 2009).

Case study research has been a widely used approach when studying energy systems from various perspectives, including Swedish research studying district heating supply, industrial energy efficiency and ventilation, energy systems analysis, and industrial symbiosis (Thollander \& Rohdin, 2011). By doing a case study, depth-specific information can be gathered. In addition, case studies can provide very detailed information about a particular subject. The disadvantage of case studies is that they are very time-consuming, and can be difficult to carry out and analyse. According to Yin (2009), it is difficult to generalize the results from a case study to a wider population until the theories have been tested in controlled conditions. Another concern with case studies is lack of consistency and objectivity since case studies sometimes are performed without systematic structure and the results and conclusions are influenced by personal opinions (Yin, 2009). This problem can be aggravated if researchers let their own opinions of the outcome of the study influence the way they interpret their data. According to Thollander and Rohdin (2011), case study research aims for analytical generalization, meaning that theories developed in the research can be general even if the results are not. These theories can later be tested in other research studies and be strengthened or contradicted.

On the building level, different Swedish buildings of various building types, construction materials, construction periods and geographical locations have been studied. The studies on this level have been done according to the research processes which are described in Section 1.5. The methods used are technical measurements, survey, categorization, BES and LCC optimization. Technical measurements have provided input data to the built models and also been used as evaluation instruments, see Papers I and II. Building energy simulation (BES) models play a significant role in the design and optimization of buildings. BES method has been used for evaluation of indoor environment, total energy use of the building and also for evaluation of energy saving potential of individual EEMs, see Papers I and II. In addition, the LCC method has been used to assess the profitability of the individual EEMs in the appended Paper I. To assess the profitability of the whole EEM package in Paper I, a Web tool called BELOK Total Project has been used. A techno-economic optimization LCC tool (OPERAMILP) has been used to identify the best combination of EEMs that would give the lowest overall cost with or without a pre-determined energy target, see Papers III, IV and V. Categorization has been used when studying a large group of buildings, see Paper V.

Results which have been generated by BES consist of energy use of the building and PMV and PPD used to evaluate the studied building's indoor environment. Results provided by LCC optimization consist of energy use of the studied building, LCC and EEM package. In addition, primary energy use and $\mathrm{CO}_{2}$ emission have also been calculated based on the building's energy use which has been provided by the above mentioned methods. The above-mentioned results 
can help house owners and housing companies clearly understand their buildings in the form of energy use, energy-saving potential and finding the cost-optimal EEM package. The results are also valuable for homeowners and housing companies who are planning for new construction or implementing major renovation of their buildings.

\subsection{Cluster level}

As mentioned in the literature study in Section 3.2, "bottom-up approach" is one of the modelling techniques used for analysing end-use energy in the residential sector. According to Swan and Ugursal, 2009, the bottom-up approach encompasses all models which use input data from a hierarchal level lower than that of the sector as a whole. By using this approach, the energy use by individual buildings or group of houses can be accounted for. The result can then be extrapolated to represent a higher level such as regional or national level. According to Swan and Ugursal, 2009, common input data for bottom-up models include dwelling properties such as geometry, envelope fabric, equipment and appliances, climate properties, as well as indoor temperatures, occupancy schedules and equipment use. This high level of detail is a strength of bottom-up modelling and gives it the ability to model technological options (Swan \& Ugursal, 2009). One drawback of this approach is the requirement that the input data be greater than the top-down model (see Section 3.2) which means that the calculation or simulation techniques of the bottom-up models can be complex.

In order to study buildings on cluster level, the "bottom-up approach" has been used which through detailed modeling of representative buildings produces an overview of the total energy use, LCC, cost optimal EEM packages and different heating systems for different clusters. The study on this level has been done in Paper V. In the current paper, results which are at building level have been up-scaled to cluster level by multiplying the number of buildings in each cluster. The results have shown that there are differences between different clusters though they are located in the same district. This has also emphasized the importance of categorization when studying a large group of buildings. Moreover, different heating systems which are costoptimal for different clusters also show that it is not optimal to have one heating system for the whole district. This in turn will lead to questions as how the energy prices should be set in order to select the most cost-optimal heating systems. Different clusters also contribute different primary energy use and $\mathrm{CO}_{2}$ emissions. The results could be more interest for municipalities, government or organizations such as Statistics Sweden, National Board of Housing, Building and Planning, Swedish Energy Agency. The above-mentioned results can be used as the basis for e.g. which EEM package should be chosen for each cluster, which heating system should be selected as most cost-optimal for each cluster and which cluster should be prioritized for a major renovation with the aim of energy efficiency.

\subsection{District level}

The study on district level is done in Paper V. In order to scale up the results from cluster level to district level simple addition has been done. For example: sum of the energy use of each cluster is the total energy use on district level. The results at this study level include the total energy use (district heating, electricity or biomass) of all the buildings in the district; the total specific energy use; the total primary energy use and $\mathrm{CO}_{2}$ emissions; and the option prices for different energy forms (district heating, electricity, biomass, etc.). In Paper V, the new price 
for district heating will be found for Cluster II and IV, respectively where the district heating will be chosen instead of wood boiler (Cluster II) and heat pump (Cluster IV). At the same time, new prices for pellet and electricity will also be found where the wood boiler or heat pump will not be beneficial for the respective clusters. The results on the district level will give an overview of the energy performance and environmental impact of all the buildings for the stakeholders. In addition, the results could also be used as a basis for urban planning or planning for energy saving, sustainable development of a large building group. 


\section{Tools and Methods}

This chapter describes all tools/methods used during my research. The methods used are technical measurement, building energy simulation (BES), life cycle cost (LCC) optimization, building categorization, BELOK, survey and calculation of primary energy and $\mathrm{CO}_{2}$ emission. The methods have been used individually or in combination during the studies. In this chapter each method will be described followed by uncertainties, advantages and disadvantages.

\subsection{Technical measurements}

Studies of indoor climate and energy efficiency often include measurements of temperature, humidity, air velocity, carbon dioxide and electricity use. Measurement can be done both instantaneously and over a long period. Instantaneous measurement means measurements which are carried out on site during the time of the visit, while other measurements are carried out during a long period of time. Measurements as evaluation instruments are of course invaluable, but the nature of the measurement in itself does not give any idea of the future, as it only says something about the past (Rohdin et al., 2010). Each type of measurement contains some uncertainty due to the type of equipment used and the manner in which measurements are made. The measurement data have been produced from the following sources which are placed in order of reliability (Raftery et al., 2011): Data-logged measurements; Spot or short-term measurement; Direct observation (site survey); Operator and personnel interviews; Operation documents (e.g. Operations \& Maintenance (O\&M) manual); Commissioning documents (e.g. as-built drawings), benchmark studies and best practice guides; Standards, specifications and guidelines; and Design stage information (e.g. the initial model). The technical measurements which have been done in Papers I and II include different types of measurements such as indoor air temperature, humidity, $\mathrm{CO}_{2}$ concentration, air velocity, and electricity use by household appliances and by the whole building. In the following sections different measurements will be described and discussed.

\subsubsection{Temperature and humidity measurements}

Indoor air temperature is one of the fundamental characteristics of the indoor environment. The indoor air temperature affects several human responses, including thermal comfort, perceived air quality, sick building syndrome symptoms and performance at work (Seppanen et al., 2006). In Papers I and II, both indoor and outdoor temperatures have been measured using the Tinytag PLUS 2 temperature logger. This is a small data logger which over time registers temperature, relative humidity, voltage, current, carbon dioxide, pressure or energy. The data loggers are available with one or two measuring points (channels) per instrument. Tinytag Plus 2 is waterproof and is known to be robust and reliable (Tinytag, 2015). The measurements from the Tiny loggers can be analysed with the Easyview software. The maximum error of loggers which have been used for measuring indoor temperature and humidity is $0.45{ }^{\circ} \mathrm{C}$ and $3 \%$ for RH (Tinytag, 2015). The collection time was ten minutes and the duration time was from two to four weeks. The loggers have been placed about one meter above the floor in the apartment in order to measure air temperature. During the measurement, some issues are important and have been considered: the sensors have not been placed close to a heat source, for example electrical appliances or fireplace; the sensors have not been exposed to sunlight or draft; the 
sensors have not been placed directly adjacent to or near the exterior wall; and the sensors have been placed at a height of $1 \mathrm{~m}-1.5 \mathrm{~m}$ above the floor level (Akander \& Johannesson, 2010).

The infrared camera (IR cameras, thermal imaging) has been used to identify thermal bridges, air leakage and moisture in a building. The IR camera can be used for whole filed measurements (e.g. measuring the temperature of the whole surface of an object), but also for measuring one room. An IR camera uses infrared detectors to generate thermal images based on surface temperatures. There are two types of IR cameras: scanners and array devices. Scanners use a single detector and mirrors to scan the field of view, while array devices consist of a matrix of detectors to resolve parts of the field of view individually. The instrument which has been used for Paper I and II is called Agema 570. The camera has a Focal Plane Array detector, with $320 \times 240$ pixels, sensitive to long-wave radiation $(\approx 293 \mathrm{~K})$. It has an uncertainty of $\pm 2{ }^{\circ} \mathrm{C}$ because of noise error, background and emittance correction, and distortion error (Cehlin, 2006; Cehlin et al., 2002; Isaksson \& Karlsson, 2006).

\subsubsection{The thermal comfort measurement}

In Paper II, thermal comfort has been investigated by using a standard method based on radiation, air velocity, air temperature, temperature of the surrounding surfaces, humidity, activity level and clothing, see also Section 4.3. The thermal comfort is calculated according to ISO - standards: ISO 7730 and ISO 7726 which provide various indices and parameters that describe the thermal comfort as operative temperature, equivalent temperature (taking into account air velocity), PMV (Predicted Mean Vote) and PPD (Predicted Percentage Dissatisfied). In Sweden, ISO 7730 is used as an indoor comfort standard. According to ISO 7730 an acceptable indoor climate is when the PMV is between -0.5 to +0.5 which corresponds to a PPD below $10 \%$ (ISO 7730, 2005). A thermal comfort data logger which is called Innova 1221 has been used to measure the PMV and PPD of two apartments of a residential building. During the measurement, Innova 1221 has been placed in the living room of each apartment. This data logger enables the user to evaluate the thermal comfort of indoor climates with a maximum error of $3 \%$. With help of Innova 1221, parameters such as indoor air temperature, humidity and air velocity will be measured which will be used for calculating PMV and PPD. In addition, this data logger can be used both offline and online to collect data. When the equipment is used online, it has to be connected with a PC and Innova 7701 software in order to view the registered data.

\subsubsection{Air flow measurements}

Too much air change rate in a building will lead to increased energy use, while insufficient air change rate will result in poor air quality. For that reason it is important to be able to properly measure the air flow. By using the tracer gas technique the amount of delivered air by the ventilation unit can be described. Tracer gas has mainly been used to measure the ventilation flow in a building with a natural ventilation system. By means of the tracer gas technique, air quality in the form of air change rate per hour can be measured (Hedin, 1994).

The tracer gas experiment consists of a gas source which emits a certain amount of tracer gas and a device which measures the concentration of the emitted gas. The concentration of the gas is constant, and the equations can be written as (Sherman, 1990): 


$$
\begin{aligned}
q_{v} & =\frac{\dot{m}}{C} \\
\frac{q_{v}}{V} & =\frac{\dot{m}}{V \cdot C} \rightarrow A C H=\frac{\dot{m}}{V \cdot C}
\end{aligned}
$$

Equation 6.1

Equation 6.2

Where $V$ is the volume $\left(\mathrm{m}^{3}\right) ; C$ is the concentration of tracer gas in the volume $\left(\mathrm{kg} / \mathrm{m}^{3}\right) ; \dot{m}$ is the mass flow of tracer gas into the volume $(\mathrm{kg} / \mathrm{s}) ; q_{v}$ is the airflow into the volume $\left(\mathrm{m}^{3} / \mathrm{s}\right)$.

The reason why this technique has been used in Paper I is that the studied buildings had natural ventilation systems, and the instantaneous measurements would thus provide uncertain value since ventilation would vary over time. In comparison tracer gas measurement thus gave an average value of the air exchange rate with two- to three-week measurement period (Akander et al., 2012).

\subsubsection{Airtightness measurement}

The blower door method is a standard way to measure the airtightness of buildings. A basic blower door system includes three components: a calibrated fan, a door-panel system and a pressure measurement device. During the measurement, the fan is mounted into the frame of an exterior doorway using the door panel system. All windows, kitchen fan and other openings should be closed. Since the indoor air is blown out of the building by the installed fan, the indoor air pressure will thus be lowered. This leads to creation of pressure difference between the inside and outside of the building. The outside air will in turn flow through all unsealed cracks and openings. By using a smoke pencil air or IR camera leakages will be detected.

On the other hand, the sensors which are installed on the blower door fan have the function of measuring the quantity of air flow passing through the fan per minute. A digital manometer measures the pressure difference in pascal $(\mathrm{Pa})$ caused by the fan, and the air flow in $\left(\mathrm{m}^{3} / \mathrm{min}\right)$ which flows through the fan at this pressure difference. The tests will be performed by varying the pressure difference between indoor and outdoor at the pressure difference between $10 \mathrm{~Pa}$ $60 \mathrm{~Pa}$ with $5 \mathrm{~Pa}$ of each step. The blower door method provides an average value of air leakage of the measured area at $\pm 50 \mathrm{~Pa}$. In real life, the air leakage is not distributed evenly in the building envelope. It is thus difficult to model air leakage which is related to a building's energy use. When the pressure difference is at $50 \mathrm{~Pa}$, by dividing the measured airflow by the measured enclosed area, the air leakage of the room with unit 1/s. $\mathrm{m}^{2}(@ \pm 50 \mathrm{~Pa}$ ) will be provided. This value can be used to compare with the air tightness of buildings/spaces and also as input data to energy simulations. In addition, this value can also be used as input data in energy simulation.

The blower door method is both a quick and precise way to detect leakage areas that affect the comfort of living and energy cost. This test will take two hours on average to perform. The air leakage which is measured by using the blower door method is not influenced by for example the thermals or wind effects. In comparison, though the air leakage can also be located by using an infrared camera, the temperature difference between indoors and outdoors will be a significant issue. The equipment which has been used during my research is called Retro Tech Blower Door System Q46 with $15 \%$ error on windless days and up to $40 \%$ error on windy days. 


\subsubsection{Electricity, space heating and domestic hot water use measurements}

In the appended Paper I, clamp meters have been used to measure the electricity use of household appliances as well as the total electricity use by the building. The measurement period was from ten days to two weeks. In order to get accurate data, instantaneous measurements of facility electricity use by fans and pumps were carried out. In Paper II, the monthly measured space heating demand and domestic hot water use are separately registered online for the retrofitted building. However for the non-retrofitted building, the space heating demand and domestic hot water use cannot be separately measured.

\subsection{Building energy simulation - IDA ICE}

To enable comparisons between survey results and measurements, and also to make predictions of consequences of implemented measures, a building energy simulation model was used, IDA Indoor Climate and Energy (ICE), which is a dynamic simulation tool used for modelling building energy performance (Björsell et al., 1999). This method has been used in Papers I and II. The mass transfer within the building is modelled using an air flow network in IDA ICE 4.5. It is implemented in a general purpose environment (IDA) where all models are available as Neutral Modeling Format (NMF) source code. This model includes simulation of operative temperatures, comfort indices, and daylight levels at arbitrary locations in the zone. The model also has balance equations for humidity, $\mathrm{CO}_{2}$ and energy. The airflow modelling and thermal condition as well as energy-related problems are key features of IDA ICE. The model also contains components for both primary and secondary HVAC systems, e.g., coils, heat exchangers, dampers, fans, and boilers.

The purpose of the model is also to predict energy use, average indoor temperature, and surface temperatures on the inside of the building. Validation of simulation software is important in order to ensure quality. Validation of IDA ICE has been carried out during the development and a large number of inter-model comparisons have been made against other programs. An extensive empirical validation exercise based on test cell measurements was also carried out within IEA SH\&C Task 22 (Björsell et al., 1999). Björsell et al., (1999) confirms that IDA ICE performed well in the validation. Moreover, IDA ICE has been validated according to both ASHRAE Standard 140-2004 and CEN Standard EN 15265-2007 (Equa Simulation, 2010; Moosberger, 2007)..

The validation of IDA ICE in comparison to CEN Standard shows accuracy level of $0-8 \%$ for heating and $0-12 \%$ for cooling. In the report of the validation of IDA ICE with respect to the ANSI/ASHRAE Standard 140 - 2004, validation of several softwares has been done. The result shows that IDA ICE performs well in the test series in comparison to other software.

\subsection{Life cycle cost optimization - OPERA-MILP}

The early stages of planning have significant influence for the future performance of a building. The same is also true when it comes to major renovation of an existing building and the optimization potential is great at a low cost. Furthermore it can be shown that early design stages determine up to $80 \%$ of building operational costs as well as of environmental impacts for new buildings. The operational costs typically strongly exceed the construction costs over a life cycle. However, the exact exceeding point as well as the ratio of initial to following costs 
depends on the quality of construction, intensity of use and building-type, as well as on considered life time of the building (Kovacic \& Zoller, 2015). The same type of conceptual problem is presented when major renovation projects are carried out where one perspective is to find a cost-optimal package of measures to include in the renovation process.

LCC optimization software called OPERA-MILP (Optimal Energy Retrofits AdvisoryMixed Integer Linear Program) (Gustafsson, 1988) has been used in Papers III, IV and V in order to find the cost-optimal energy renovation strategy for a building during its whole life cycle. OPERA-MILP is based on mixed integer linear programming (MILP) and was first developed at the Division of Energy Systems in Linköping University during the 1980s. The software has been used for studying both multi-family buildings (Gluch \& Gustafsson, 2015; Gustafsson, 1990, 2000, 2001), and also one heritage single-family building (Broström et al., 2014).

The input data to OPERA-MILP requires building information, e.g. $U$-values of the building, indoor air change rate, indoor and outdoor air temperatures, costs and performance for different measures, energy prices and the real discount rate. The mathematical model of OPERA-MILP includes an objective function which comprises various LCC costs related to the energy efficiency renovation of the building, and many other constraints which determine building's energy use which has to be balanced in order to keep the indoor temperature at a certain level. By minimizing the objective function, the lowest LCC and the corresponding EEM package will be found for the building. The outputs include (1) dimensioned building's power (W); (2) annual energy demand (kWh) of the building; (3) an optimal combination of different energy efficiency measures (EEMs); (4) energy savings specified for different energy carriers (kWh); (5) the total costs of each measure (SEK); and (6) the total LCC for the building (SEK). This LCC represents the sum of the investment, running cost and residual value. The investment cost includes the construction cost of the suggested heating system, as well as costs for each suggested measure and the inevitable retrofit cost. The inevitable retrofit cost includes costs of e.g. erecting scaffolding, dust cover, painting and washing the façade, and is thus independent of the building part concerned and does not influence the optimal thickness of e.g. insulation. The running cost is the life cycle cost of running the installed heating system which is labeled LCC $C_{\text {Energy }}$ from here on. The expression total LCC can thus be stated as in Equation 6.3. Postprocessing may also include $\mathrm{CO}_{2}$-emission calculation.

$$
\mathrm{LCC}_{\text {tot }}=\mathrm{LCC}_{\text {Investment }}+\mathrm{LCC}_{\text {Energy }}-\mathrm{LCC}_{\text {Residual value }} \quad \text { Equation } 6.3
$$

In order to make the costs comparable the present value method is used, which transfers all the cost during the project time to a base year. For a future non-recurring cost, $G$, the present value (PV) can be calculated using Equation 6.4. For annually recurring costs, $F$, the present value can be calculated as in Equation 6.5.

$$
\begin{array}{ll}
\mathrm{PV}=G \cdot(1+r)^{-n} & \text { Equation } 6.4 \\
\mathrm{PV}=F \cdot \frac{1-(1+r)^{-n}}{r} & \text { Equation } 6.5
\end{array}
$$

In Equation 6.4 and Equation 6.5, $r$ is the real discount rate, $n$ is the number of years until event $G$ or $F$ will occur. Since the parameters have strong influence on the results as well as 
being difficult to predict, it is of interest to include them in a sensitivity analysis. In addition, the prognosis of energy price development is also difficult and highly uncertain and will thus also be included (Kovacic \& Zoller, 2015).

The EEMs which are included in OPERA-MILP are (1) attic floor insulation; (2) ground floor insulation; (3) external wall insulation from outside; (4) external wall insulation from inside; (5) window replacement ${ }^{3}$; (6) weather-stripping; and (7) heating system installation ${ }^{4}$. The cost functions $(C)$ of the EEMs are described differently depending on whether it is an insulation measure (Equation 6.6), window replacement (Equation 6.7) or heating system (Equation 6.8) (Gustafsson, 1988).

$$
\begin{array}{ll}
C_{\text {insul. }}=C_{1}+C_{2}+C_{3} \cdot t & \text { Equation } 6.6 \\
C_{\text {window }}=C_{4} \cdot A_{\text {window }} & \text { Equation } 6.7 \\
C_{\text {heating unit }}=C_{5}+C_{6} \cdot P+C_{7} \cdot P & \text { Equation } 6.8
\end{array}
$$

In Equation 6.6, $C_{\text {insul. }}$ is the total insulation cost, $C_{1}$ presents the maintenance (inevitable) cost of erecting scaffolding, demolition and building a new external façade. $C_{2}$ and $C_{3}$ are connected to the direct insulation cost, including material and labour cost etc. and $t$ is the added insulation thickness. $C_{\text {window }}$ is the cost of window replacement, $C_{4}$ represents the specific cost and $A_{\text {window }}$ is window area. The same structure is used for heating systems where $C_{5}$ and $C_{6}$ are specific economic constants and, $P$ is the power of the unit. $C_{7}$ is the cost of pipe works and other associate construction costs that do not scale with size. $C_{5}$ is the investment cost of the heating system. This structure of cost functions when combine with cost of inevitable retrofit work and costs of energy etc. allows us to minimize the LCC and thus obtain a mathematical optimum.

The Swedish database called 'Wikell Section' database (Wikells Sektionsfakta in Swedish) (Wikells building calculation, 2016) was used to compile these cost functions. The database includes up to date prices, labour costs and costs for all parts of a construction project.

\subsubsection{Restrictions on energy use}

Adding the possibility to explore pre-set energy targets or to remove unsuitable EEMs from for example a preservation point of view, exists in the form of adding additional constraints in the optimization. The methodology for adding additional energy constraints is illustrated in Figure 7. The left (a) represents the total process. If no additional constraints are added the optimized solution is obtained $\left(E_{\mathrm{LCC}}\right)$. If however, $(\mathrm{b})$, an energy target $\left(E_{1}\right)$ is added that is lower than the optimum $E_{\mathrm{LCC}}$ a new solution is found. The third option is that a target value $E_{2}$ higher than $E_{\mathrm{LCC}}$ is sought, then a process of removing the least cost efficient EEMs is used.

In order to include specific aspects of preserving the heritage value of a building unsuitable measures are removed from the optimization process. These considerations are decided before optimization. The impacts of the implemented EEMs on the building's heritage value are

\footnotetext{
${ }^{3}$ Window type I: $2+1$ glazed. Window type II: 3 glazed with LE glass. Window type III: 3 glazed $+\mathrm{LE}+\mathrm{Gas}$.

${ }^{4}$ Three heating systems are included, a wood boiler (WB), a ground water heat pump (HP) and a district heating (DH).
} 
shown in Broström et al., (2014). The three types of LCC optimization with or without different additional energy constraints are illustrated in Figure 7.

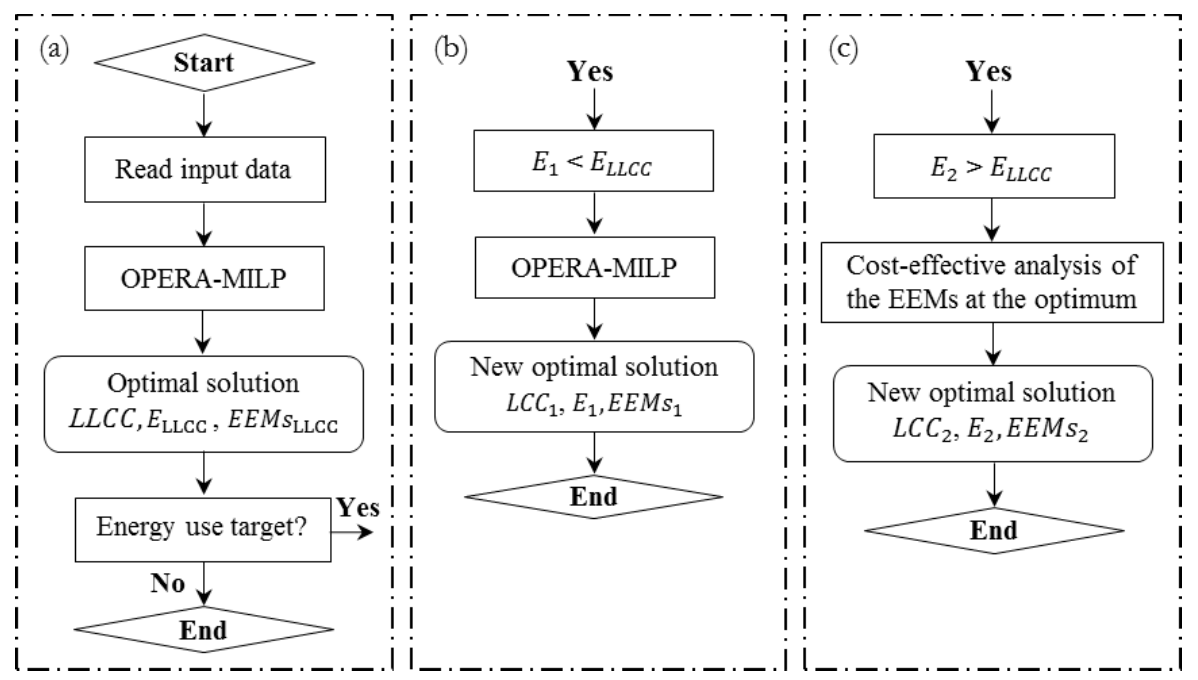

Figure 7: The three types of LCC optimization with or without additional energy constraints.

\subsubsection{Restrictions on implemented EEMs}

As mentioned in Chapter 1, in the current studies the difference between listed and nonlisted buildings has been studied from energy saving and cost-optimal perspectives. In order to combine the evaluation of heritage value with energy and cost effectiveness of the building, the focus is on the exterior appearance of the studied building in this study, which means that no changes to exterior appearance (external wall insulation from outside and window replacement) and only minor material changes are allowed. In addition, interior insulation of the external walls is not considered to be a viable choice and is thus not included. One reason is to avoid condensation in the wall which in turn will lead to moisture and mold problems, while another reason is to avoid reduction of the living area and the fact that the effect of some thermal bridges cannot be reduced, such as joints between intermediate floors and external walls. Figure 8 illustrates consequences of restricting EEMs when building's heritage value is considered.
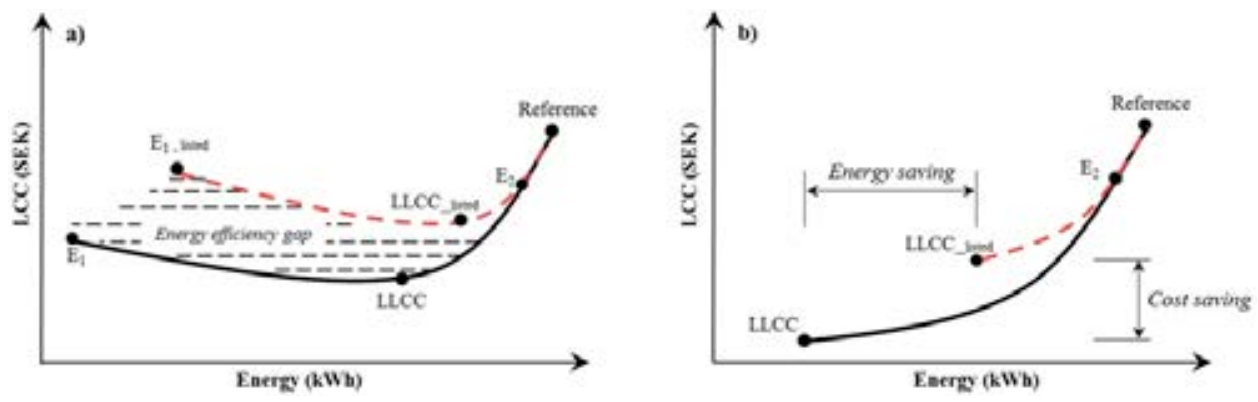

Figure 8: Restrictions of EEMs for listed (red) and non-listed buildings (black).

As Figure 8 shows two different curves with different characterizations could be accessed when EEMs are restricted for listed buildings. In Figure 8a the LLCC is between the energy 
targets $E_{1}$ and $E_{2}$ for both listed and non-listed buildings. Both the listed and non-listed buildings have the same LCC as the reference case and $\mathrm{E}_{2}$ case. This indicates that the same EEM package could be implemented for both building types when energy target $E_{2}$ is reached. For the LLCC case and $\mathrm{E}_{1}$ case, the LCC and EEM packages are different for different building types. As shown in Figure 8a, at the LLCC point the energy use and LCC of listed building are higher than the non-listed building. This indicates that different EEM packages have been implemented for the different building types since some of the EEMs which are suitable for the non-listed building are not allowed to be implemented on a listed building. Moreover, the figure also shows that the non-listed building has higher energy efficiency than the listed building. Due to the restrictions on EEMs for listed buildings, it is difficult for listed buildings to reach the same energy target $\left(\mathrm{E}_{1}\right)$. The stricter the energy target, the greater the energy efficiency gap becomes.

If the building is in bad condition which means the building has high energy use, another tendency of the curves for listed and non-listed buildings can be shown in Figure 8b. Both building types have the same LCC at the reference case and when the energy target $\mathrm{E}_{2}$ is reached. Moreover, the EEM package is suitable for both building types when this energy target is reached. Since the building is in bad condition, more EEMs are considered as costoptimal measures at the LLCC point. With help of the suggested EEM package the building could be renovated to passive house standard already at the LLCC. Therefore other energy targets as $E_{2}$ which are lower than $E_{\text {LLCC }}$ do not need to be investigated since the suggested EEM packages will result in higher LCC with little lower energy use. However, it is difficult for listed building to save as much energy as the non-listed building does due to the restrictions on the EEMs.

\subsubsection{Wikells database}

The Wikells data base includes compilations of different construction parts with different costs and technical values in both book form and on the web. The database includes a complete calculation system with databases for new construction, renovation, electricity, air and ventilation (Wikells building calculation, 2016).

\subsection{Primary energy factor and $\mathrm{CO}_{2}$ emission factor}

\subsubsection{Primary energy factor}

The primary energy assessment has been investigated in Papers I, IV and V. The primary energy factors used in Papers I, III, IV and V came from a Swedish energy investigation report titled "An energy efficient Sweden" (Swedish Government, 2008). The importance of using the primary energy factor is to analyze the total natural resources required to produce the final energy use and also to avoid sub-optimization.

The primary energy factor of electricity used in Papers I, IV and V is based on Nordic marginal electricity production, the electricity is thus produced from a coal power plant. There are some differences between the production process for district heating and electricity. The first difference is that district heating is local while electricity is transnational. The second difference is that the local district heating system can be changed faster than the international electrical system in practice. According to (Swedish Government, 2008), the district heating 
networks in Sweden have been divided into three groups. The first group contains the networks that deliver maximum $30 \mathrm{GWh}$ district heating per year; the second group contains networks which have annual delivery between 31 and $500 \mathrm{GWh}$, and the third group includes networks that deliver $500 \mathrm{GWh}$ district heating per year. The analysis from SOU 2008:25 (Swedish Government, 2008) shows that the primary energy factor for networks included in group one is 1.21 during the base years $2001-2005$, while the primary energy factors for the networks included in groups two and three are 0.97 and 0.78 , respectively.

The analysis of primary energy factor of oil is based on the input data from the Swedish Petroleum Institute (SPI) (Swedish Government, 2008). The input data is based on studies of different fuels that take into account the entire production, transportation, and distribution chain. The report (Swedish Government, 2008) has thus suggested 1.2 as the primary energy factor for final use of oil products. The used primary energy factor of biofuels is suggested by SOU 2008:25 (Swedish Government, 2008) which is 1.2. The analysis includes extraction, refining, transportation and distribution of biofuels.

\subsection{2 $\mathrm{CO}_{2}$ emission assessment}

There are different $\mathrm{CO}_{2}$ emission factors of district heating for different cities in Sweden, see Papers I, IV and V. The Swedish average production value (SADHP) has been used for $\mathrm{CO}_{2}$ emissions for district heating. The main difference between these factors is caused by the proportion of fossil fuels used in the district heating production process. For example, in Paper IV, Luleå and Falun have a relatively low proportion of fossil fuel usage of $5 \%$ and $3 \%$ respectively in their district heating production (The property owners, 2014). In comparison, Malmö has a relatively high proportion of fossil fuel of $38 \%$ (The property owners, 2014). The energy company Fortum AB in Stockholm aims for heat supply systems from a global systems perspective. In addition the net balance to the power grid is also included in the $\mathrm{CO}_{2}$ emission factor calculation. This results in Fortum $\mathrm{AB}$ having relatively high $\mathrm{CO}_{2}$ emissions.

The $\mathrm{CO}_{2}$ emission factors for electricity used in the current studies are Swedish average electricity mix production value (SAEP), Nordic electricity mix production (NEMP) and Nordic marginal electricity produced by coal condensing power plant (NMEP). The SAEP has the lowest $\mathrm{CO}_{2}$ emission factor. However, in recent years, this approach has been replaced by the Nordic electricity mix, which considers the import and export of electricity to neighboring countries. The NEMP will reflect the electricity system's physical appearance where the Nordic countries (excluding Iceland) have basically unlimited transmission capacity in comparison with other European countries where transport is limited. The third method is called NMEP which means the last produced unit of electricity by using the electricity system. To decide which electricity is marginal production depends on the total electricity consumption at each moment. During peak load hours, the marginal electricity will be produced by a coal power plant, based on the idea that this is the most expensive production unit in the system, and thus the one that is first removed when the peak load is reduced. At other times, during low load hours, the marginal electricity production will have low carbon intensity and be based on sources such as wind-power or hydropower (SABO, 2013; The property owners, 2014).

Biomass as a renewable energy source can be considered both as unlimited or limited resource. According to Harvey \& Axelsson (2010a) the bioenergy market is limited to low and 
high grade wood fuels (for instance forestry logging residues and pellets, respectively). In comparison to fossil fuels which have a world market and electricity which has a European market, wood fuel has no homogenous European market. Rather there are many local markets and furthermore wood fuel prices can vary significantly between different countries, e.g. due to different national policy instruments. However, the increasing requirements on renewable energy will stimulate the development of European bioenergy (Harvey \& Axelsson, 2010a).

During the current studies, biomass has been considered as a limited resource with potential marginal users of coal power plants, where wood fuel can be combusted in boilers, thereby enabling fossil coal usage to be partly replaced by wood fuel at relatively low investment costs (Berndes \& Hansson, 2007; Harvey \& Axelsson, 2010b). With the increasing $\mathrm{CO}_{2}$ charge, the users are more willing to pay for wood fuel than coal power plants. For one MWh of reduced use of biomass locally can result in a $336 \mathrm{~kg}$ reduction of $\mathrm{CO}_{2}$ emission globally (Harvey \& Axelsson, 2010a).

In other scenarios, biomass has also been considered products from forest residuals or recycled wood chips (Gode et al., 2011). When biomass is considered as a forest residual, the major $\mathrm{CO}_{2}$ emission source consists of fossil fuel use for logging, collection of raw materials and distribution to heating plants. The impacts on biodiversity of the forest are not included in the analysis (Gode \& Enström, 2009). Recycled wood chips consist of packaging timber and similar materials. The quality of the fuels use has great impact on the $\mathrm{CO}_{2}$ emission factor, e.g. the recycled wood-chips should be free from painted and impregnated wood. The $\mathrm{CO}_{2}$ emission factor used for forest residuals and recycled materials are $19 \mathrm{~kg} / \mathrm{MWh}$ and $16 \mathrm{~kg} / \mathrm{MWh}$.

\subsection{Categorization}

The structure of the categorization method is based on the CityGML concept which is a common information model for the representation of 3D urban objects (CityGMLWiki, 2015). The use of city models (GIS) has been increasingly popular in the visualization of the energy performance of individual buildings or districts, from either measured values or energy audits in studies of urban environments (Johansson et al., 2016). The method has also been used in the following studies: Johansson et al., (2016) have developed a city energy model based on the requests and need for visualization from a group energy advisors; Aksoezen et al.,(2015b) have studied the energy use of all the building stock in the city of Basel, Switzerland based on a GIS-based depository; Caputo et al., (2013) have developed a methodology able to characterize the energy performance of the built environment in a city to evaluate the effects of different energy strategies; Fabbri et al., (2012) have analyzed the energy performance of entire zones of a city by using GIS map projection. The GIS database contains data, such as type of building, number of floors, year of construction, built area and land surface. This method has been developed by using building sector information on Visby.

The pre-process of the categorization method starts by identifying available data and defining what data is missing (Berg, 2015). If needed additional data must be collected in situ. A review of available data on listed building sector involves that both on-going and completed surveys and projects are assessed with regards to topicality, reliability and overall quality. The collected data also sets the limits for the categorization process where the data is used to 
identify the typical buildings of a selected building sector or district. The three main types of data are; general building data, geometrical building data and energy data.

The categorization method is divided into four main steps which are number of floor, boundaries, floor area and volume. The first step addresses the issue of clustering the total amount of buildings according to the number of stories each building has. The next step involves dividing the buildings in accordance with their boundaries, i.e. the number of adjoining walls. The third step involves a calculation of the floor area based on external dimensions. After the third step, several building categories have been chosen. The buildings are sorted by volume and the buildings that fall outside the standard deviation are excluded.

\subsection{Total project tool - BELOK}

The BELOK "Total project tool" is a web tool which combines economic profitability and energy efficiency in an overall project. In the current study (see appended Paper I), the tool is used to assess the economic profitability of the whole energy efficiency measure package based on a discount rate which is decided by organization or company. The tool shows the rate of return in a chart with $X$-axis stands for "investment" and $Y$-axis stands for "annual cost savings". The "Total project tool" approach is very useful since it helps to achieve substantial energy savings that meet the property owner's economic profitability requirements. Therefore it is an appropriate tool to be used before making any investment decisions. This approach can only assess energy-related measures. In addition, in which order the energy efficient measures are placed will also affect the economic profitability result by using this tool.

\subsection{Survey - "My home environment"}

To be able to compare the measured with the simulated values of the occupant's perception of the buildings' indoor environment, a questionnaire approach has been used. The MM survey used in Paper II is an example of a standardized epidemiological survey and has been widely used in Sweden. An epidemiological method is useful for describing the occupants' perceptions and experiences of the indoor environment and is effective when evaluating the results of this type of retrofit (Andersson et al., 1988). The first version of this questionnaire was developed in 1986 at the Department of Occupational and Environmental Medicine, Örebro University Hospital (Norlén \& Andersson, 1993). It has been validated and considered a reliable tool when studying indoor environment issues (Sundell \& Lindvall, 1993), and has been used in a large number of studies. The form has subsections, such as: background factors, disturbing environmental factors, psychosocial factors, prevalence of symptoms among occupants, perception of indoor environment (air temperature, noise, perceived air quality, etc.), and medical history of allergic diseases. Survey is the most common method used to investigate the opinions of the occupants (Isaksson \& Karlsson, 2006). Other projects which have also used survey to investigate energy demand and indoor climate include Bluyssen et al., (2003); Dorizas et al., (2015); Holopainen et al., (2015); Isaksson \& Karlsson, (2006); La Fleur et al., (2017); Rohdin et al., (2012) and Rohdin et al., (2014). 


\section{Results and discussions}

This chapter includes results from the studies and answers to the four research questions mentioned in Section 1.3 followed by discussions.

Research questions I and II investigate the energy efficiency problems of buildings on the building level. The tools used are BES, measurement, survey and LCC optimization. Research question III has been investigated on the building level and also on higher levels such as cluster level and district level. Research question IV investigates questions on cluster level and district level. The tools used are categorization and LCC optimization.

\subsection{Research question I}

"How can BES, technical measurements and surveys to study the energy use and indoor environment of Swedish multi-family buildings be combined?"

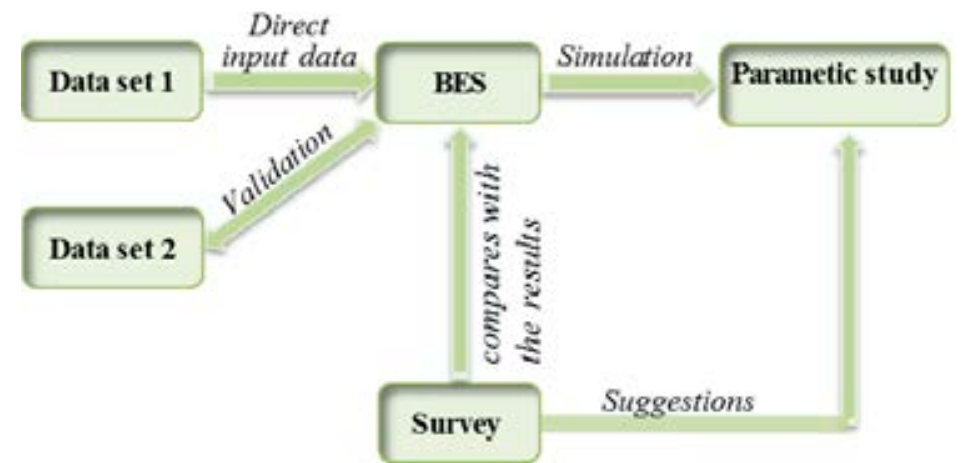

Figure 9: Combination of technical measurement, BES and survey to study building's energy use and indoor environment.

In the appended Papers I and II several methods have been combined and used in order to investigate the energy use and to analyze the indoor environment of the studied buildings. The combined methods include on-site measurements, BES and standardized indoor environment questionnaire. This approach is illustrated in Figure 9. By combining measurements, simulation and surveys the building's energy use and indoor environment can be studied both from a technical and a social perspective. In addition, this way of studying the building also provides a holistic and a systematic approach.

As Figure 9 shows the combined method starts with on-site measurements to provide detailed technical information about the performance of the buildings. The measurements have been categorized by their sources and also according to what purpose they have been used for, see Table 3. The first dataset (Data set 1) of measurements have been used as the input data of the BES models such as local weather profile (outdoor temperature, solar radiation, wind velocity, etc.), buildings' domestic hot water use, and electricity used by household and facility. Some of the measurements which have been done are in order to validate other measurements. For example: the measured $\mathrm{CO}_{2}$ concentration explains the indoor temperature variation; IR camera supplements the blower door test and will identify thermal bridges and leakage of the 
building. The second data set (Data set 2) was used to validate the models. For example: the measured room's temperature and the monthly energy use of the building.

The survey which has been used is called "Miljö och Medicinsk enkät (MM enkät)". The purpose with the survey is mainly for indoor environment investigation. In Paper II, the survey was distributed to the households at the beginning of the study. This method will help us to investigate how the households experience the indoor environment. According to the results of the survey, the parameter study will be done by use of the validated BES model in order to e.g. improve the indoor environment of the retrofitted building. In addition, by using the survey the result such as PMV (Predicted Mean Vote) and PPD (Predicted Percentage of Dissatisfied) from the BES will be better explained. In the appended Paper II, the survey results show that "too cold during winter", "variation of room temperature" and "draft" are the three biggest problems reported for non-retrofitted buildings. The results from the simulation of the nonretrofitted buildings have also shown the same problem. In addition, the results from the survey showed that residents from the retrofitted building experienced high indoor air temperature during summer.

Parametric studies which have been made in Paper II is in order to reduce the current overheating problem. The suggestions include e.g. installing external/internal blinds or replacing the existing windows with windows with lower $g$-value, lowering indoor temperature with one degree. The results from the parametric study have shown that adding external blinds from May 15 to September 15 from $10 \mathrm{am}-12 \mathrm{pm}$ on the east side and $12 \mathrm{pm}-3 \mathrm{pm}$ on the west side seems to be the best option for improving the indoor climate during summer.

Table 3: Categorization of the measurements which have been used in building BES models.

\begin{tabular}{|c|c|c|}
\hline \multirow[t]{2}{*}{ Source } & \multicolumn{2}{|c|}{ Purpose } \\
\hline & Input data to BES (Data set 1) & Validation of the BES (Data set 2) \\
\hline Data-logged measurement & $\begin{array}{l}\text { Indoor temperature of measured apartments } \\
\mathrm{CO}_{2} \text { concentration } \\
\text { Air temperature in stairwell } \\
\text { Outdoor air temperature } \\
\text { Weather profile } \\
\text { Electricity use of household appliances } \\
\text { The total electricity use of the building } \\
\text { Electricity use of the building facility }\end{array}$ & $\begin{array}{l}\text { Indoor air temperature of measured } \\
\text { apartments } \\
\text { Outdoor air temperature } \\
\text { PMV and PPD }\end{array}$ \\
\hline Spot or short measurement & $\begin{array}{l}\text { Air temperature in stairwell } \\
\text { Blower door } \\
\text { IR camera } \\
\text { Efficiency of MVHR }\end{array}$ & - \\
\hline Direct observation & - & - \\
\hline $\begin{array}{l}\text { Operator and personnel } \\
\text { interviews }\end{array}$ & - & - \\
\hline Operation documents & Hot tap water use of the building & District heating use \\
\hline $\begin{array}{l}\text { Commissioning } \\
\text { documents }\end{array}$ & $U$-values of the envelop & - \\
\hline $\begin{array}{l}\text { Benchmark studies and } \\
\text { best practice guides }\end{array}$ & SMHI weather profile & - \\
\hline $\begin{array}{l}\text { Standards, specifications } \\
\text { and guidelines }\end{array}$ & $\begin{array}{l}\text { DHW } \\
\text { Internal heat generation }\end{array}$ & - \\
\hline
\end{tabular}


The measurements include two datasets which are shown in Table 3. Dataset 1 which is used as direct input data of the BES model, includes both measured data and also external data. As shown in Table 3, most of the direct input data included in dataset 1 is provided by data-logged measurements or short-term measurements which provide high reliability of input data to the BES models. This in turn will also lead to lower deviation of the BES model compared to the real data. In Papers I and II, the measured indoor air temperature is used for calculating the control temperature of each apartment in the BES model. The measured electricity used by household appliances, air temperature in stairwell, airtightness and ventilation system efficiency are used directly as input data for the BES models.

The measured weather profile is important to validate the model with the local weather in order to build a BES model with high accuracy. In addition, in Paper II the measured $\mathrm{CO}_{2}$ concentration of one apartment has been used as complementary data when analyzing the measured indoor air temperature, i.e., a sudden increase in measured indoor temperature which also appears in the $\mathrm{CO}_{2}$ concentration measurement during the same period. This can be explained e.g. as guest visit or other activities held in the apartment. This in turn has helped to create a detailed internal heat profile which in turn will lead to higher accuracy of the built BES model. In the appended Paper I, IR camera has been used to identify thermal bridges, air leakage and moisture in the buildings. Identified moisture in the apartments has been shown for the residents and the housing company and protective measures have been taken.

Data set 2 includes all data used for validating the built BES model. The built BES model has been validated by measured indoor air temperature and monthly district heating use in the appended Paper II. The measured outdoor air temperature has been used as input data of the weather profile. The deviations of the annual specific energy use between the measured and simulated values of the corresponding model are less than $2 \%$, which indicates the built BES model is in good agreement with reality. By comparing the simulated PMV and PPD with the questionnaire results, a better understanding of the indoor environment of both the retrofitted and non-retrofitted building has been accessed. In addition, the simulated model of the retrofitted building has also been used for parameter studies with the purpose of finding better solutions to solve the overheating problem which was both mentioned in the questionnaire and shown by the simulation.

\subsection{Research question II}

"How can an LCC optimization method be used a) to find a cost-optimal EEM package; b) to explore the lowest LCC; and c) to reach certain energy targets, for the Swedish listed buildings?"

The OPERA-MILP has been used for LCC optimization analysis in the appended Papers III, IV and V. Four cases are investigated: (1) reference case; (2) $20 \%$ reduction in energy use based on the 2020 energy target; (3) lowest LCC (LLCC); and (4) $50 \%$ reduction in energy use based on the 2050 energy target; (5) maximum energy saving. The studied objects included in the appended Papers III, IV and V include a single-family listed wood building from the 1920s, a listed multi-family building from the 1890s, and a building group including 920 listed residential buildings in the historical town of Visby in Sweden. The listed building studied in Paper IV has also been considered a non-listed building in order to compare the results of 
energy use, LCC and EEM packages. The results from Paper III, IV and V show that it is costoptimal for both the listed and non-listed buildings to achieve the 2020 energy target. However, the results show that it is difficult for listed buildings to reach the 2050 target. Figure 10 illustrates the energy use, total LCC and energy efficiency measures in different cases for the non-listed and listed buildings, see Paper IV. Figure 10 revealed the same behaviour for the non-listed building compared to the listed one as mentioned in Section 6.3.2 and Figure 8.

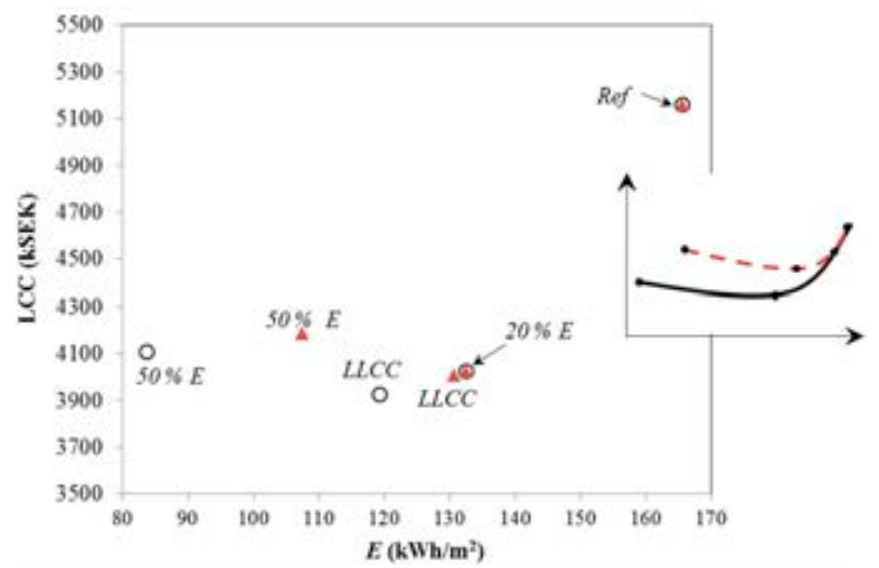

Figure 10: LCC, Energy use of listed (triangle) and non-listed (circle) building in the Paper IV.

As shown in Figure 10, the building's energy use in the reference case is $165.5 \mathrm{kWh} / \mathrm{m}^{2}$ before any energy-efficient measures are introduced and the total LCC is $5159 \mathrm{kSEK}$. In the reference case the total LCC includes the installation cost of district heating system, inevitable cost and energy cost of running the district heating. As shown in Figure 10, at the optimum point (LLCC), the non-listed building's total LCC is $3926 \mathrm{kSEK}$ and the energy use will be $119 \mathrm{kWh} / \mathrm{m}^{2}$, which indicates a $28 \%$ energy use reduction.

For the listed building the external wall insulation from outside has to be removed as an option since it will cause visual and material changes. The total LCC and energy use for the listed building at the optimum point will then become $4009 \mathrm{kSEK}$ and $130.7 \mathrm{kWh} / \mathrm{m}^{2}$ respectively, which represents a $21 \%$ energy use reduction. When the additional $20 \%\left(\mathrm{E}_{2}\right)$ constraint is added, the total LCC and energy use are the same for both the listed and non-listed buildings. This is since the suggested EEMs are suitable for the building whether it is considered a non-listed or a listed building. In comparison, when a $50 \%$ energy use reduction $\left(\mathrm{E}_{1}\right)$ is required, the total LCC and energy use are different for the non-listed and listed building, since the external wall insulation and window replacement are not allowed when a building's heritage value is considered. Additionally, it is also shown that both the non-listed and listed buildings can achieve a $20 \%$ reduction in energy use without major renovation.

But reaching the long-term national target of energy saving up to $50 \%$ requires major renovation, which is in conflict with the preservation requirements. Figure 10 also shows that the listed building is not capable of reaching the $50 \%$ energy use reduction without allowing additional insulation of the exterior walls. The maximum energy use reduction for the listed building is $35 \%$. The optimal point for the listed building appears earlier, which means higher energy use and total LCC compared to the non-listed one. 
Clearly there is a need to treat listed buildings and non-listed buildings separately when making energy efficiency plans from an energy saving and cost-optimal perspective as well as conservation aspects. Different EEMs are suitable for different building types. The 2050 target may be achieved by the non-listed buildings, but when the constraints relevant to listed buildings are added the cost-optimality changes as some EEMs which are in direct conflict with the building's heritage value may not be implemented. This has some policy implications, as the current national target does not include specific targets for different building types, e.g. listed buildings and buildings without conservation requirements. Furthermore, from a costoptimality perspective it would be beneficial to break down the long-term targets into measurable milestones, so that those buildings which cannot achieve the 2050 target directly are still on the right path to reduce their energy use.

When using OPERA-MILP, an EEM package can be compiled. The EEMs which are included in the package are sorted from most cost-efficient to least cost-efficient. With the EEM package, the cost-optimal solution can be found for the building. In an EEM package, the profitable measures finance the less profitable measures, thereby making it possible to achieve a well-balanced energy use reduction from both an economic and an efficiency point of view. Parameters such as discount rate and energy price will vary in the sensitivity analysis since they are the parameters which have great impact on the present value and LCC will thus affect the optimal solution. The current studies also show that the installation cost for district heating is higher than heat pump, but the running cost for district heating is lower than for heat pump from a life cycle perspective.

\subsection{Research question III}

"How can EEMs and building supply energy systems affect the primary energy use and $\mathrm{CO}_{2}$ emissions?"

\subsubsection{Primary energy use assessment}

The primary energy assessment has been investigated in Papers I, IV and V. Since the electricity has the highest primary energy factor, this in turn leads to higher primary energy use of buildings heated by direct electricity. In cases when the building is heated by heat pump, the primary energy use will be reduced due to the high COP of heat pump. As shown in Table 4, the primary energy use is different when different heating systems are used. In the reference case, the building is heated by district heating, and the primary energy use is $209.1 \mathrm{kWh} / \mathrm{m}^{2}$. In the lowest LCC (LLCC) case, three heating systems have been chosen for the building in order to compare the primary energy use. The results show that the primary energy use is highest when the building is heated by wood boiler and lowest when the building is heated by heat pump. Though the primary energy factor of electricity (2.5) is higher than biomass (1.2), the COP of the heat pump used is 2.5 , which is higher than the wood boiler's efficiency which is $75 \%$ in Paper IV.

Otherwise, when the same heating system is used, the building's primary energy use depends on the implemented EEM package. For example, in the appended Paper I, the primary energy use in $\mathrm{kWh} / \mathrm{m}^{2} \cdot \mathrm{yr}$ by implementing the first EEM package is lowest due to the largest building energy use reduction. In comparison, the primary energy use is highest when 
implementing the third EEM package since this has the lowest energy use reduction. The same trend can also be seen in Papers IV and V. With the same heating system but different EEM packages, the primary energy use is highest with the EEM package which results in the lowest energy. In comparison, the primary energy use is lowest with the chosen EEM package which results in largest energy use reduction.

Table 4: Primary energy use by the non-listed building in the reference case and the lowest LCC case by using different heating systems.

\begin{tabular}{l|c|c|c}
\hline \multirow{2}{*}{ Case } & \multicolumn{2}{|c|}{ Energy end use } & Primary energy use \\
\cline { 2 - 4 } & $\left(\mathrm{kWh} / \mathrm{m}^{2}\right)_{\text {heat }}$ & $\left(\mathrm{kWh} / \mathrm{m}^{2}\right)_{\text {electricity }}$ & $\mathrm{kWh} / \mathrm{m}^{2}$ \\
\hline Ref $(\mathrm{DH})$ & 165.5 & - & 209.1 \\
\hline LLCC $(\mathrm{HP})$ & - & 47.8 & 119.5 \\
\hline LLCC $(\mathrm{DH})$ & 119.1 & - & 150.4 \\
\hline LLCC $(\mathrm{WB})$ & 119.1 & - & 190.6 \\
\hline \hline
\end{tabular}

To summarize, with the same EEM package but different heating systems, the primary energy use will be highest with the heating system which has the highest primary energy factor. However, the primary energy use is lower when the building is heated by heat pump than directly by electricity. This is because of the heat pump's higher COP. On the other hand, when the heating system is the same, which means the primary energy factor is the same, the more energy which can be saved by the implemented EEM package, the lower the primary energy use is, and vice versa.

\subsection{2 $\mathrm{CO}_{2}$ emission assessment}

The same trend can also be seen for $\mathrm{CO}_{2}$ emissions. With the same heating system, which means the $\mathrm{CO}_{2}$ emission factor is the same, the $\mathrm{CO}_{2}$ emissions depend on the energy saving potential of the implemented EEM package. On the other hand, when the heating systems are different, $\mathrm{CO}_{2}$ emissions are based on the heating systems $\mathrm{CO}_{2}$ emission factor. The higher the $\mathrm{CO}_{2}$ emission factor, the higher the $\mathrm{CO}_{2}$ emissions will be. However, there are different perspectives when choosing $\mathrm{CO}_{2}$ emission factor for one heating system. This will also affect the results.

When the heating system is changed, which means the $\mathrm{CO}_{2}$ emission factors are different, the heating system with the highest $\mathrm{CO}_{2}$ emission factor will result in the highest $\mathrm{CO}_{2}$ emissions. The $\mathrm{CO}_{2}$ emissions vary depending on which type of heating system the building is connected to. In the reference case, when the building is connected to district heating, two different $\mathrm{CO}_{2}$ emission factors have been used to evaluate the building's $\mathrm{CO}_{2}$ release: Lulea and Swedish average production. As shown in Figure 11, when the building is connected to the district heating system, the $\mathrm{CO}_{2}$ emissions by the non-listed buildings are $3.1 \mathrm{ton} / \mathrm{yr}$ and 12.9 ton/yr. The main difference between these emissions is caused by the proportion of fossil fuels used in the district heating production process. Luleå has a relatively low proportion of fossil fuel usage of $5 \%$ of its district heating production. This thus results in lower $\mathrm{CO}_{2}$ emissions than when the SADHP is used. 


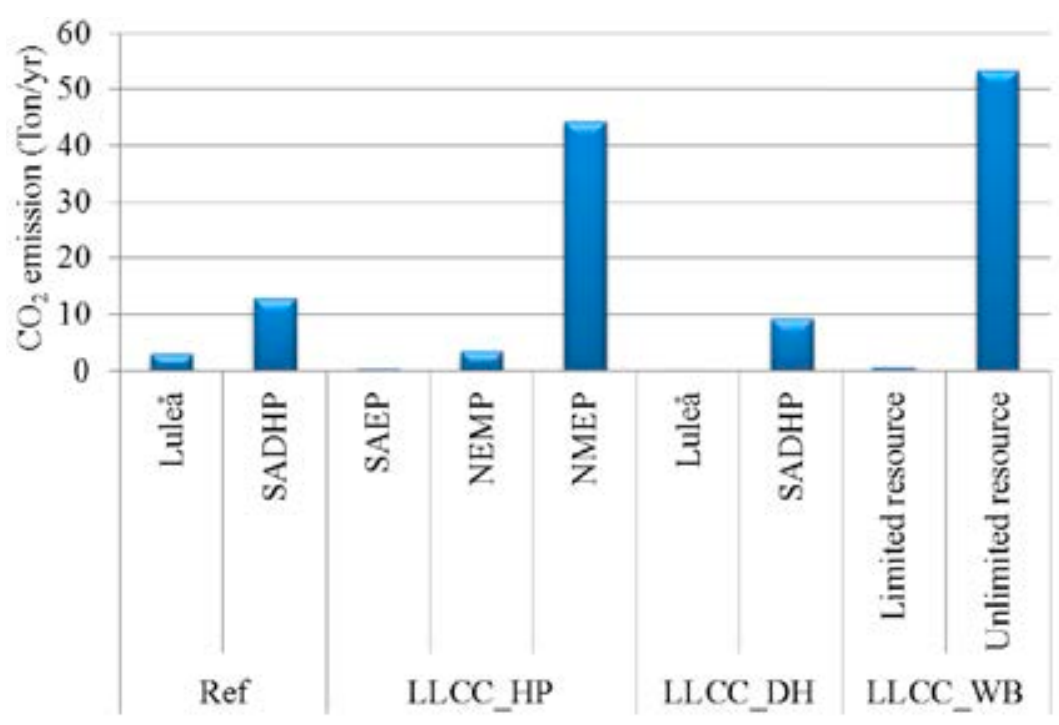

Figure 11: $\mathrm{CO}_{2}$ emissions by the non-listed building in Paper IV in the reference and LLCC case by using different heating systems.

In case LLCC, when the building is heated by heat pump, three different $\mathrm{CO}_{2}$ emission factors of electricity have been investigated: Swedish average electricity production (SAEP), Nordic electricity mix production (NEMP) and Nordic marginal electricity production (NMEP). The $\mathrm{CO}_{2}$ emissions by the non-listed buildings are highest when the NMEP method is used, 44 ton/year, and lowest when the SAEP method is used, 0.5 ton/yr. When the building is connected with wood boiler, the $\mathrm{CO}_{2}$ emissions are highest at 53.4 ton/yr when biomass is considered as limited resource and lowest when biomass is considered unlimited resource which is 0.6 ton/yr. Buildings using the SAEP method will result in the lowest $\mathrm{CO}_{2}$ emissions since this method does not take into account the import or export of electricity to other countries. The $\mathrm{CO}_{2}$ emissions will be higher by using the other two methods. The advantage of evaluating $\mathrm{CO}_{2}$ emission by using the NEMP method is that this method reflects the actual emissions from the production of electricity. In addition, the emissions from all electricity use within the system boundary will be equal to the total emissions. The NMEP has the highest $\mathrm{CO}_{2}$ emissions since the electricity is assumed to be produced by a coal condensing plant in this project.

As shown in Figure 3 in Section 2.1, district heating is the most common heating method used by both multi-family buildings and commercial buildings. Furthermore, as shown in the current studies the $\mathrm{CO}_{2}$ emission factors of local district heating companies are relatively lower than the national value. From an energy system perspective, it is not efficient to implement EEMs which will save district heating, since these measures will replace part of district heating used for hot tap water and also increase the building's electricity use. Furthermore, in order to reduce $\mathrm{CO}_{2}$ emissions in Europe, NEMP and NMEP perspectives are recommended.

\subsection{Research question IV}

"How can a categorization strategy and LCC optimization be used to extrapolate the findings from individual buildings to a district level?" 
In the appended Paper V, a group of listed buildings in the Swedish town of Visby has been studied. A total of 920 buildings are included in the analysis. In order to approach a systematic study the buildings have been studied on three different levels, which are building level, cluster level and district level. A so-called "categorization" method has been used in order to identify typical buildings which will represent all of the studied buildings. Categorization will benefit a more comprehensive understanding of the studied building group (Berg, 2015). The preprocess of the categorization method starts with identifying available data and defining what data is missing (Berg, 2015). If needed, additional data must be collected in situ. By means of the categorization method, the studied building group has been categorized into different groups based on number of floor, boundary, floor area and volume. A systematic study of a large building group is presented in Figure 12.

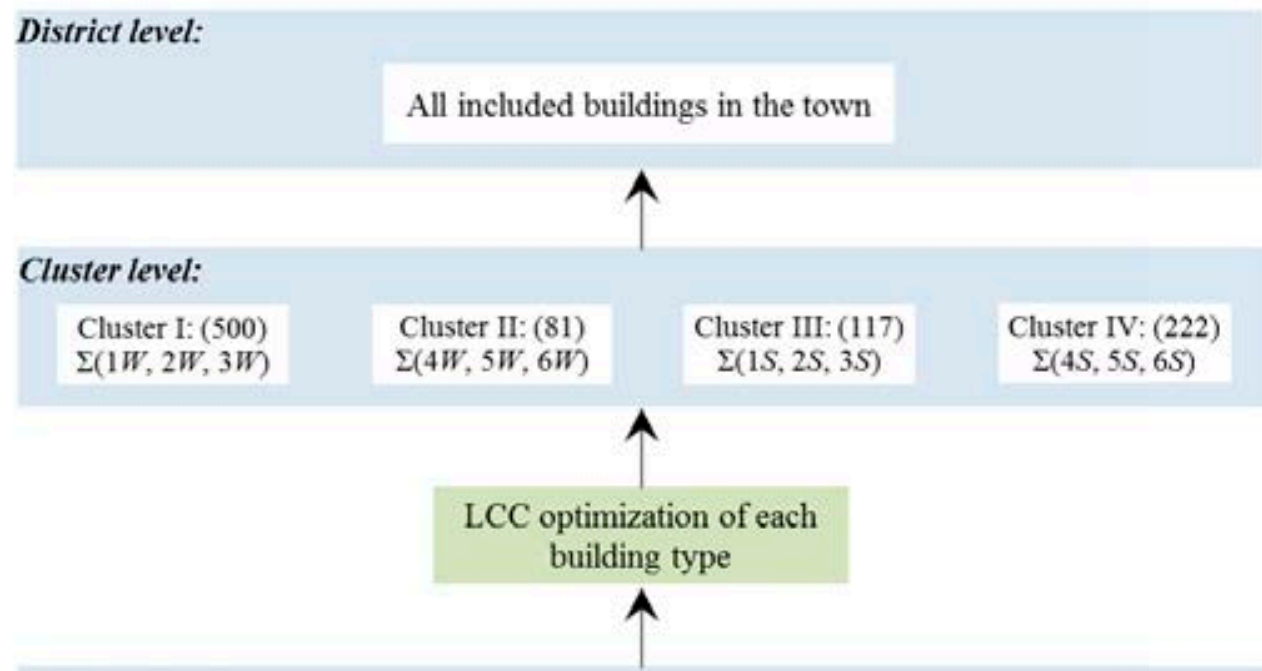

\section{Building level:}

$1 W:(309) ; 1 S:(55)$

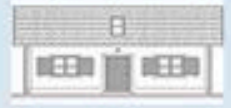

$4 W:(33) ; 4 S:(75)$

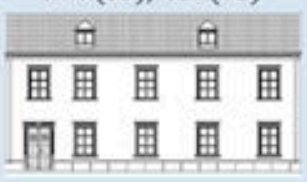

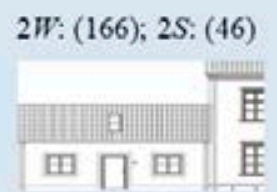

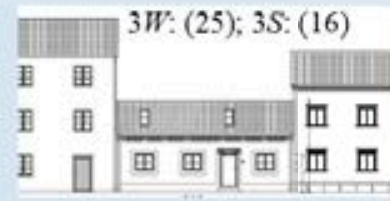

$6 W:(18) ; 6 S:(64)$
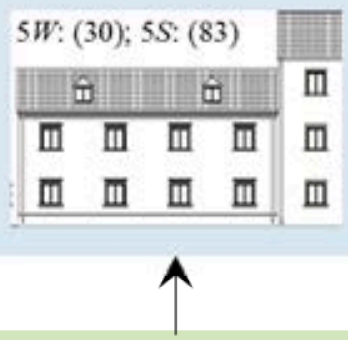

Building categorization

Figure 12: Overview of the methods application on the studied building stock. 
As shown, the categorization results in four different building categories: Cluster I includes 500 one-story wood buildings $(1 \mathrm{~W}, 2 \mathrm{~W}$ and $3 \mathrm{~W})$ which is the largest group of buildings in Visby; Cluster II includes 81 multi-story wood buildings ( $4 \mathrm{~W}, 5 \mathrm{~W}$ and $6 \mathrm{~W})$; Cluster III includes 117 one-story stone buildings ( $1 S, 2 S$ and $3 S$ ) and Cluster IV includes 222 multi-story stone buildings $(4 S, 5 S$ and $6 S$ ). There are 920 buildings which are included in the clusters, which represent $88 \%$ of all the buildings and $70 \%$ of the total built volume of the listed town of Visby. The 128 excluded buildings represent $30 \%$ of the total building volume.

Typical buildings from each category have been identified which in turn have been optimized by using OPERA-MILP. With help of OPERA-MILP, the EEM package, LCC and energy use of each typical building will be found. Post-processing also includes $\mathrm{CO}_{2}$ emissions and primary energy calculations. The LCC and energy use on the cluster and district levels will be upgraded based on the number of the typical buildings.

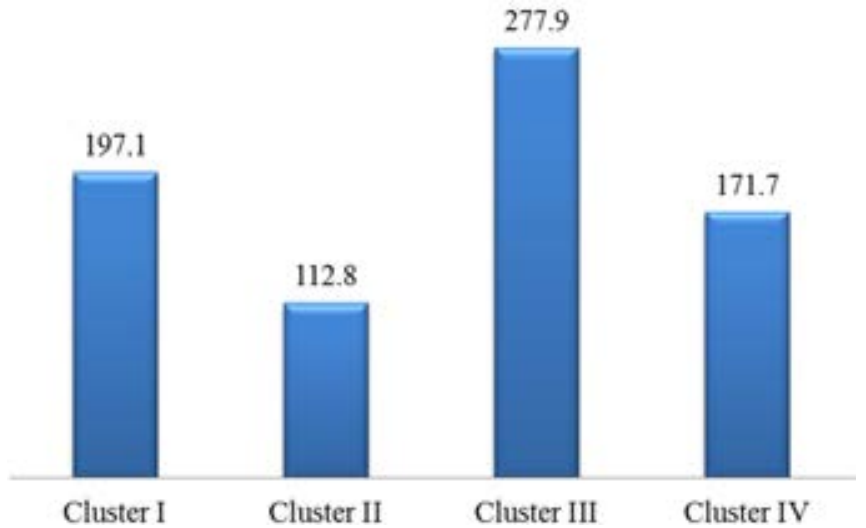

Figure 13: The specific energy use $\left(\mathrm{E} \mathrm{kWh} / \mathrm{m}^{2}\right)$ of Cluster I, II, III \& IV in the reference case.

Figure 13 shows, the annual specific energy use of different cluster is different. Cluster III has the highest specific energy use and Cluster II has the lowest one.

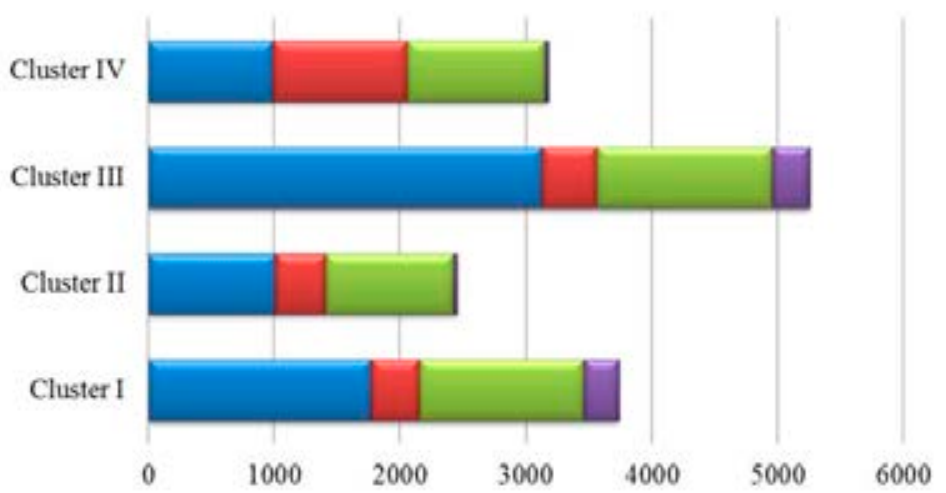

Figure 14: The total investment cost $\left(\mathrm{SEK} / \mathrm{m}^{2}\right)$ and running cost of cluster I, II, III \& IV in the lowest LCC case (blue: running cost, red: Installation cost, green: Inevitable cost, purple: EEM package). 
In Figure 14 the total LCC of each cluster in the lowest LCC case presented in detail. The investment costs are broken down in different costs of EEMs, inevitable costs and installation costs of different heating systems for different categories. As shown in Figure 14 the installation cost per heated area for Cluster IV is highest, which uses heat pump. In comparison, the installation costs per heat area for district heating (Cluster I and III) and wood boiler (Cluster II) are much lower. On the other hand, the running costs of district heating and wood boiler are higher than it is for heat pump. The costs for EEM package installation are higher for Cluster I and III than they are for Cluster II and IV since more EEMs are suggested to be implemented for Cluster I and III than for Cluster II and IV in the LLCC case. The suggested EEM package for Cluster I includes attic floor insulation $(8-10 \mathrm{~cm})$, floor insulation $(26-28$ $\mathrm{cm}$ ), weather-stripping and window replacement. The suggested EEM package for Cluster II includes attic floor insulation $(10-12 \mathrm{~cm})$, weather stripping and window replacement. The suggested EEM package for Cluster III includes attic floor insulation $(12 \mathrm{~cm})$, floor insulation $(28 \mathrm{~cm})$, weather-stripping and window replacement. The suggested EEM package for Cluster IV includes attic floor insulation $(10 \mathrm{~cm})$, weather-stripping and window replacement.

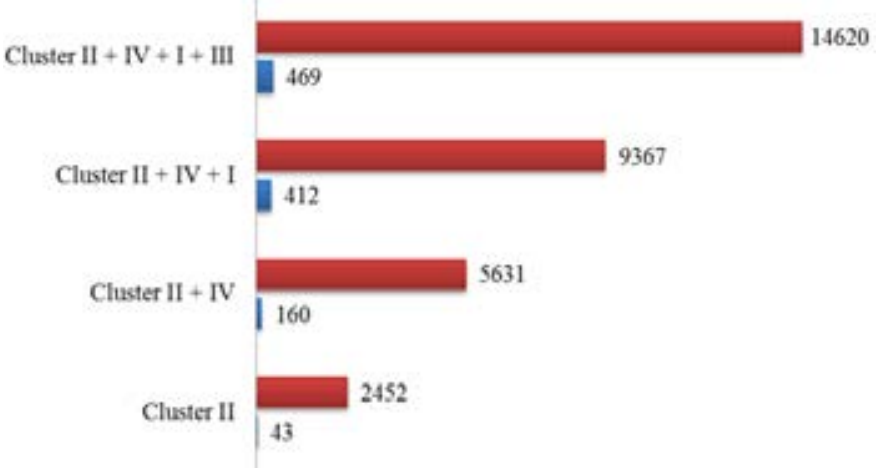

Figure 15: Saved energy (GWh, blue) and LCC (SEK $/ \mathrm{m}^{2}$, red) after implementing different EEM packages on the respective clusters during 50 years.

Figure 15 shows the total saved energy and the LCC during 50 years by implementing different EEM packages on the respective clusters. Results from the current study show that it is cost optimal to start to implement EEMs on Cluster II which has lowest LCC, then follows by Cluster IV, Cluster I and lastly Cluster III. The total saved energy varies between $43 \mathrm{GWh}$ to $469 \mathrm{GWh}$ and the accumulated specific LCC in SEK $/ \mathrm{m}^{2}$ varies between $2452 \mathrm{SEK} / \mathrm{m}^{2}$ and $14620 \mathrm{SEK} / \mathrm{m}^{2}$.

The current study shows a systematic methodology when studying a large building group. The bottom up approach and the combination of categorization and LCC optimization have played an important role in the overall urban planning from energy and economic perspectives. The results from different levels are interested and useful for different stakeholders. Stakeholders such as house owners and housing companies are interested in results from the building level. While stakeholders such as government, municipality and organizations are interested in results from cluster and district level. The methodology used in the current study also shows a way of finding cost-optimal solutions while the buildings' heritage values are still preserved for a large listed building group. 


\section{Conclusions}

In this chapter the conclusions from the appended papers are presented for each research questions.

The important role that the renovation of residential buildings will play in reducing the total energy used by the Swedish building sector and also in reducing primary energy use and $\mathrm{CO}_{2}$ emissions on both the national and global levels has been the impetus for the studies included in this thesis. The case study method which has been used in most of the present studies is particularly beneficial when studying a complex problem involving questions of "how" and "why". The bottom-up method used in the last appended paper is shown to be an appropriate approach which can generate both detailed information of individual buildings and a systematic overview for the cluster or district level.

Research question I - How can BES, technical measurements and surveys to study the energy use and indoor environment of Swedish multi-family buildings be combined?

The combination of BES, technical measurements and surveys provides a holistic approach for evaluation of energy use and indoor environment of a residential building. Technical measurement provides detailed technical information about the building, while on-site visits provide information such as location and appearance. The survey used in the current study can provide detailed information on internal heat loads and how buildings are used and how residents experience the indoor environment. The internal loads and airing by residents have great impact on both a building's energy use and indoor climate. The outcomes from the measurement, on-site visit and survey will be used as input data for the build BES model or for validating the build model. The outcome from the case studies presented in this thesis also confirmed that this triangulation method, i.e. BES, technical measurements and surveys, is comprehensive, appropriate and efficient.

Research question II - How can an LCC optimization method be used a) to find cost-optimal $E E M s, b)$ to explore the lowest LCC, c) to reach a certain energy targets of the Swedish listed buildings?

This thesis presents a unique combination of methods when using LCC optimization, BES and other forms of data collection and categorization. In addition, the Swedish listed building stock has not been studied before in a similar manner. Moreover, the categorization method based on the GIS method has been used in order to identify the type of buildings on a city or district level. The results from the current study show that the 2020 energy target of the building sector can be achieved by all the studied building types and that the total LCC of these buildings are below the cost-optimal point.

In comparison, the 2050 energy target for the building sector may be achieved by non-listed buildings, but when the constraints relevant to listed buildings are added the cost-optimality changes as some EEMs are in direct conflict with the building's heritage value and may not be implemented. This has policy implications, as the current national target does not include specific targets for different building types, e.g. listed buildings and buildings without conservation requirements. Furthermore, from a cost-optimality perspective it would be 
beneficial to break down the long-term targets into measureable milestones, so that those buildings which cannot achieve the 2050 target directly are still on the right path to reduce their energy use (UFOS, 2013). In order to achieve the 2050 energy target, considering the energy efficiency measures as a package rather than as individual measures is also shown to be important.

\section{Research question III - How can EEMs and building supply energy systems affect primary energy use and $\mathrm{CO}_{2}$ emissions?}

The primary energy factors used in the present study for electricity and district heating are 2.5 and 1.2. For the $\mathrm{CO}_{2}$ emissions, different perspectives have been considered, since electricity is more transnational than district heating. The higher the energy saving, the lower the primary energy use becomes, and vice versa. With the same energy saving, the heating system with higher primary energy factor results in higher primary energy use.

For $\mathrm{CO}_{2}$ emissions, factors provided for district heating systems of different cities and for the Swedish average district heating production (SADHP) have been used. The proportion of fossil fuels used in the studied district heating systems creates the differences between these factors. The $\mathrm{CO}_{2}$ emission factors used for electricity are SAEP, NEMP and NMEP, where SAEP has the lowest $\mathrm{CO}_{2}$ emission factor while NMEP has the highest. The advantage of using NEMP is that it considers the import and export of electricity to neighboring countries, while NMEP considers electricity is marginal production by coal. The high $\mathrm{CO}_{2}$ emission result by using NMEP will help to improve environmental awareness associated with major renovation of the buildings, which in turn will guide reduction in electricity use. The $\mathrm{CO}_{2}$ emission factor for district heating is lower than for NEMP and NMEP. Thus, EEMs or converting a building's supply energy systems proposed to help buildings connected to a district heating system, in order to reduce the energy use or LCC are not constantly effective from an energy system perspective. In most cases, these measures will reduce the district heating demand and the produced electricity in the CHP plant as well as increase of the building's electricity use. In case when the biomass is considered as a limited resource, measure such as investment on a bio-fuel boiler is not favorable from the $\mathrm{CO}_{2}$ emission point of view.

Research question IV - How can a categorization strategy and LCC optimization be used to extrapolate the findings from individual buildings to a district level?

The current study has shown that by combining categorization method and LCC optimization method, the energy use, LCC and EEM package of buildings on a district level can be studied. By using the categorization method, $88 \%$ of the studied historical town could be included. Looking at the covered building volume instead, the categorization showed that the weighted volume of the 920 buildings represents roughly $70 \%$ of the historical town. As a result, categorization is thus an appropriate method for creating typical buildings which in turn can be studied individually by using LCC optimization method. The study shows that different buildings included in the same town have to be considered differently since their constructions and sizes are not homogenous. The study shows that different EEMs are suitable for different building clusters. The way of studying a large building group on three different levels is progressive and systematic. This will provide both detailed understanding of individual 
buildings and also an overview on district level. Using categorization and LCC optimization methods to study a large building group on three levels will help the building sector to reduce their energy use, primary energy use and $\mathrm{CO}_{2}$ emissions in a more efficient way. 


\section{Future studies}

The future studies include further development of energy efficiency and finding cost-optimal EEM package on cluster and district level as well as the proposed categorization method. In addition, during the future study the system boundary will be expanded outside the building which means that the energy supply system (e.g. Combined Heat and Power (CHP) system) which supplies energy to a building or a building sector in a city will be included. The study includes investigation of how the suggested cost-optimal EEM package will affect the peak load of a CHP plant which is connected to a city district. When combining OPERA-MILP with IDA ICE, building's indoor environment and energy efficiency of a cluster of buildings will be shown. In addition, combination of OPERA-MILP with IDA ICE with an energy system optimization program such as MODEST will show how suggested cost-optimal EEM packages implemented on the studied buildings affect the CHP based districted heating system which is connected to the studied buildings.

Furthermore, the developed methodology could also be tested on other building types such as industrial buildings, office buildings, schools and health care buildings. Interviews and questionnaires related to energy use and indoor environment could also be used in order to give a social-technical perspective on energy efficiency of a building rather than a purely technical perspective. The combination of IDA ICE, OPERA-MILP and MODEST can also be used on the above-mentioned building types. 


\section{References}

Abel, E., \& Elmroth, A. (2007). Buildings and Energy - a systematic approach (Vol. 2007). Stockholm: Formas.

Akander, J., Cehlin, M., \& Persson, G. (2012). Energy efficiency of multi-family buildings - Eleven buildings Part I (In Swedish: Energieffektivisering av flerbostadsfastigheter - Elva lokala exempel år 2012 Del I). Regional Council Gefle (Vol. 2012:16 Pa).

Akander, J., \& Johannesson, G. (2010). Chapter 2: Experimental methods for the energy charaterization of buildings. In M. Santamouris (Ed.), Energy performance of residential buildings: a practical guide for energy rating and efficiency (pp. 26-56). Abingdon, U.K: Taylor \& Francis.

Aksoezen, M., Daniel, M., Hassler, U., \& Kohler, N. (2015a). Building age as an indicator for energy consumption. Energy \& Buildings, 87, 74-86. https://doi.org/10.1016/j.enbuild.2014.10.074

Aksoezen, M., Daniel, M., Hassler, U., \& Kohler, N. (2015b). Building age as an indicator for energy consumption. Energy \& Buildings, 87, 74-86. https://doi.org/10.1016/j.enbuild.2014.10.074

AlingsåsEnergy. (2015). Our district heating. Retrieved January 27, 2017, from http://www.alingsasenergi.se/fjarrvarme/vart-fjarrvarmenat

Alsmyr, T. (2014). Injustering och optimering av värmesystem ibefintlig fastighet. Akademin för Teknik och Miljö Avdelningen för bygg - energi - och miljöteknik; Högskolan i Gävle.

Andersen, R. K., Fabi, V., \& Corgnati, S. P. (2016). Predicted and actual indoor environmental quality: Verification of occupants' behaviour models in residential buildings. Energy and Buildings, 127, 105-115. https://doi.org/10.1016/j.enbuild.2016.05.074

Andersson, A., \& Larsson, D. (2013). Renovation of multi-family buildings in the million program from an energy and profitability perspective. Sweden. Retrieved from http://studentarbeten.chalmers.se/publication/179068renovering-av-flerfamiljsbostader-inom-miljonprogrammet-ur-ett-energi-och-lonsamhetsperspektiv

Andersson, K., Fagerlund, I., Bodin, L., \& Ydreborg, B. (1988). Questionnaire as an instrument when evaluating indoor climate. Healthy Buildings, Vol 1:139-.

ANSI/ASHRAE. (2004). Standard 55: Thermal Enviornment Conditions for Human Occupancy. American Society of Heating, Refrigerating and Air-Conditioning Engineers.

Ascione, F., Bianco, N., De Masi, R. F., \& Vanoli, G. P. (2013). Rehabilitation of the building envelope of hospitals: Achievable energy savings and microclimatic control on varying the HVAC systems in Mediterranean climates. Energy and Buildings, 60, 125-138.

Aste, N., Adhikari, R. S., \& Buzzetti, M. (2012). Energy retrofit of historical buildings: an Italian case study. Journal of Green Building, 7(4), 144-165.

Balaras, C. A., Gaglia, A. G., Georgopoulou, E., Mirasgedis, S., Sarafidis, Y., \& Lalas, D. P. (2007). European residential buildings and empirical assessment of the Hellenic building stock, energy consumption, emissions and potential energy savings. Building and Environment, 42(3), 1298-1314. https://doi.org/10.1016/j.buildenv.2005.11.001

Bennett, J., \& Norman, G. (1987). Life cycle costing and risk management. Construction Management and Economics, $V 5$ special.

Berg, F. (2015). Categorising a historic building stock - an interdisciplinary approach. Uppsala University Campus Gotland.

Berndes, G., \& Hansson, J. (2007). Bioenergy expansion in the EU: cost-effective climate change mitigation, employment creation and reduced dependency on imported fuels. Energy Policy, 35(12), 5965-5979.

Björk, C. (2012). Rekordårens småhus - väl värda att bevara. In B. Johannson (Ed.), Miljonprogrammet - utveckla eller avveckla? (p. 45). Stockholm: Formas.

Björsell, N., Bring, A., Eriksson, L., Grozman, P., Lindgren, M., Sahlin, P., ... Vuolle, M. (1999). IDA indoor 
climate and energy. In Proc. of the 6-th IBPSA Conference (pp. 1035-1042).

Bluyssen, P. M., Cox, C., Boschi, N., Maroni, M., Raw, G., Roulet, C. A., \& Foradini, F. (2003). European project HOPE (health optimization protocol for energy-efficient buildings). TNO.

Bonakdar, F., Dodoo, A., \& Gustavsson, L. (2014). Cost-optimum analysis of building fabric renovation in a Swedish multi-story residential building. Energy and Buildings, 84, 662-673. https://doi.org/10.1016/j.enbuild.2014.09.003

Bonomo, P., \& De Berardinis, P. (2014). PV integration in minor historical centers: Proposal of guidecriteria in post-earthquake reconstruction planning. Energy Procedia, 48(0), 1549-1558. https://doi.org/10.1016/j.egypro.2014.02.175

Boverket. (2009). Energy Performance Certificate- three steps towards benefits. National Board of Housing Building and Planning.

Boverket. (2010a). Building regulation: BBR 17 (In Swedish: Boverkets föreskrifter om ändring $i$ verkets byggregler: BBR17). Boverket, Karlskrona, Sweden (Vol. BFS 2010:2).

Boverket. (2010b). PBL, Plan and Building Law (2010:900). (Plan- och bygglag (2010:9009)) 8 Chapter $17 \S$ Available at $<\mathrm{http}$ //www.boverket.se/sv/PBL-kunskapsbanken/teman/kulturvarden/kulturvarden-i-plan--och-bygglagen/krav-pa-byggnadsverk-och-tomter/varsamhetskravet/>. Swedish National Board of Housing, Building and Planning.

Boverket. (2013). Boverkets regulation: BBR20 (In Swedish: Boverkets föreskrifter om ändring $i$ verkets byggregler). National Board of Housing Building and Planning, Karlskrona, Sweden (Vol. BFS 2013:1).

Boverket. (2016). BBR 24. Karlskrona. Retrieved from https:/www.google.se/search?q=boverket\&ie=utf$8 \&$ oe $=$ utf-8\&client=firefox-b\&gfe_rd=cr\&ei=MLCtWLy5JITD7gTj-YX4Dg\#q=BBR24

BPIE. (2011). Europe's Buildings Under The Microscope - A countyry-by country review of the energy performance of buildings. Buildings Performance Institute Europe. Brussels, Belgium. https://doi.org/ISBN: 9789491143014

Braulio-Gonzalo, M., Bovea, M. D., Ru??, M. J., \& Juan, P. (2016). A methodology for predicting the energy performance and indoor thermal comfort of residential stocks on the neighbourhood and city scales. A case study in Spain. Journal of Cleaner Production, 139, 646-665. https://doi.org/10.1016/j.jclepro.2016.08.059

Braulio-Gonzalo, M., Bovea, M. D., Ruá, M. J., \& Juan, P. (2016). A methodology for predicting the energy performance and indoor thermal comfort of residential stocks on the neighbourhood and city scales. A case study in Spain. Journal of Cleaner Production, 139, 646-665. https://doi.org/10.1016/j.jclepro.2016.08.059

Broström, T., Eriksson, P., Liu, L., Rohdin, P., Ståhl, F., \& Moshfegh, B. (2014). A Method to Assess the Potential for and Consequences of Energy Retrofits in Swedish Historic Buildings. The Historic Environment, 5(2), 150-66. https://doi.org/10.1179/1756750514Z.00000000055

Broström, T., Eriksson, P., Rohdin, P., \& Ståhl, F. (2012). A method to assess the effect of energy saving interventions in the Swedish stock of historic buildings. In HERITAGE 2012.

Caputo, P., Costa, G., \& Ferrari, S. (2013). A supporting method for defining energy strategies in the building sector at urban scale. Energy Policy, 55, 261-270. https://doi.org/10.1016/j.enpol.2012.12.006

Cehlin, M. (2006). Visualization of air flow, temperature and concentration indoors: whole-field measuring methods and CFD.

Cehlin, M., Moshfegh, B., \& Sandberg, M. (2002). Measurements of air temperatures close to a low-velocity diffuser in displacement ventilation using an infrared camera. Energy and Buildings, 34(7), 687-698.

CityGMLWiki. (2015). Basic information - CityGML-Wiki.

Coakley, D., Raftery, P., \& Keane, M. (2014). A review of methods to match building energy simulation models to measured data. Renewable and Sustainable Energy Reviews, 37, 123-141.

Commission-Climate, E. (2015). 2020 Climate and Energy action package. 
Dalenbäck, J.-O. (2007). Solar heating using roof module collectors - Examples from new and existing building areas. Charlmers Publication Library. Göteborg. Retrieved from

http://publications.lib.chalmers.se/publication/24915-solar-heating-using-roof-module-collectors-examplesfrom-new-and-existing-building-areas

Danish Government. (2014). Strategy for energy renovation of buildings, (May).

De Berardinis, P., Rotilio, M., Marchionni, C., \& Friedman, A. (2014). Improving the energy-efficiency of historic masonry buildings. A case study: A minor centre in the Abruzzo region, Italy. Energy and Buildings, 80, 415-423.

De Wit, S., \& Augenbroe, G. (2002). Analysis of uncertainty in building design evaluations and its implications. Energy and Buildings, 34(9), 951-958.

Diamond, R. (2011). Evaluating the energy performance of the first generation of LEED-certified commercial buildings. Lawrence Berkeley National Laboratory.

Djongyang, N., Tchinda, R., \& Njomo, D. (2010). Thermal comfort: A review paper. Renewable and Sustainable Energy Reviews, 14(9), 2626-2640.

Dorizas, P. V., Assimakopoulos, M.-N., \& Santamouris, M. (2015). A holistic approach for the assessment of the indoor environmental quality, student productivity, and energy consumption in primary schools.

Environmental Monitoring and Assessment, 187(5), 1-18.

Ekberg, L. E. (2003). Chapter 1: An Introduction to Indoor Climate as a Concept Section 3.2: Indoor air quality Section 3.3: Sound Section 3.4: Light. In P. E. Nilsson (Ed.), Achieving the desired indoor climate - Energy efficiency aspects of system design. Denmark: Narayana Press.

Equa Simulation, A. B. (2009). IDA ICE getting started. Stockholm, Sweden. Retrieved from www.equa.se/deliv/ICE4GettingStartedEng.pdf

Equa Simulation, A. B. (2010). Validation of IDA Indoor Climate and Energy 4.0 with respect to CEN Standards EN 15255-2007 and EN 15265-2007.

Eriksson, P., Hermann, C., Hrabovszky-Horváth, S., \& Rodwell, D. (2014). EFFESUS methodology for assessing the impacts of energy-related retrofit measures on heritage significance. The Historic Environment: Policy \& Practice, 5(2), 132-149.

European Commission. (2013). Green paper: A 2030 framework for climate and energy policies.

European Commission-Energy. (2012). Energy Efficiency Directive. Retrieved from http://www.eceee.org/policyareas/Buildings/FAQ-recast-of-EPBD/FAQ-existing-buildings/

Fabbri, K., Zuppiroli, M., \& Ambrogio, K. (2012). Heritage buildings and energy performance : Mapping with GIS tools. Energy \& Buildings, 48, 137-145. https://doi.org/10.1016/j.enbuild.2012.01.018

Gluch, P., \& Baumann, H. (2004). The life cycle costing (LCC) approach: a conceptual discussion of its usefulness for environmental decision-making. Building and Environment, 39(5), 571-580.

Gluch, P., \& Gustafsson, M. (2015). Acceptance and Use of LCC as a Decision Support Tool for Renovation Investments. In ICCREM2015@sEnvironment and the Sustainable Building (pp. 821-828). ASCE.

Gode, J., \& Enström, R. (2009). Guide lines to choice of method during calculation of the impact of changed energy use in the Swedish environmental goals (In Swedish: Vägledning till metodval vid beräkning av påverkan från förändrad energianvändning på de svenska miljömålen). IVL: Swedish Environmental Research Institute (Vol. B1822).

Gode, J., Martinsson, F., Hagberg, L., Öman, A., Höglund, J., \& Palm, D. (2011). Estimated emission factors for fuels, electricity, heat and transport in Sweden (In Swedish: Miljöfaktaboken 2011-Uppskattade emissionsfaktorer för bränslen, el, värme och transporter). Värmeforsk Rapport, 1183.

Grytli, E., Kværness, L., Rokseth, L. S., \& Ygre, K. F. (2012). The Impact of Energy Improvement Measures on Heritage Buildings. Journal of Architectural Conservation, 18(3), 89-106. 
Gustafsson, S.-I. (1988). The Opera Model -Optimal Energy Retrofits in Multi-family Residences. Division of Energy Systems, Linköping University (Vol. No.180).

Gustafsson, S.-I. (1990). A computer model for optimal energy retrofits in multi-family buildings. Swedish Council for Building Research (Vol. D21:1990).

Gustafsson, S.-I. (1998a). Mixed integer linear programming and building retrofits. Energy and Buildings, 28(2), 191-196.

Gustafsson, S.-I. (1998b). Sensitivity analysis of building energy retrofits. Applied Energy, 61, 31-38.

Gustafsson, S.-I. (2000). Optimisation and simulation of building energy systems. Applied Thermal Engineering, 20(18), 1731-1741.

Gustafsson, S.-I. (2001). Optimal fenestration retrofits by use of MILP programming technique. Energy and Buildings, 33(8), 843-851.

Hall, T., \& Vidén, S. (2005). The Million Homes Programme: a review of the great Swedish planning project. Planning Perspectives, 20(3), 301-328.

Hallberg, R. (2014). Issues with the indoor environment in damp buildings An investigation of measures issued to prevent dampness in the indoor environment (In Swedish: Inomhusmiljöproblem i fuktiga byggnader: En utredning av åtgärder vid fuktrelaterade inomhusmiljöproblem).

Harvey, S., \& Axelsson, E. (2010a). No Title. Scenarios for Assessing Profitability and Carbon Balances of Energy Investments in Industry.

Harvey, S., \& Axelsson, E. (2010b). Scenarios for assessing profitability and carbon balances of energy investments in industry. Chalmers University of Technology.

Hedin, B. (1994). Tracer gas measurement techniques (In Swedish: Mätteknik med spårgas). Falculty of Engineering LTH. Falculty of Energineering Lund University.

Hemsath, T. L., \& Alagheband Bandhosseini, K. (2015). Sensitivity analysis evaluating basic building geometry's effect on energy use. Renewable Energy, 76, 526-538. https://doi.org/10.1016/j.renene.2014.11.044

Holopainen, R., Salmi, K., Kähkönen, E., Pasanen, P., \& Reijula, K. (2015). Primary energy performance and perceived indoor environment quality in Finnish low-energy and conventional houses. Building and Environment, 87, 92-101.

Hong, T., Taylor-Lange, S. C., D’Oca, S., Yan, D., \& Corgnati, S. P. (2016). Advances in research and applications of energy-related occupant behavior in buildings. Energy and Buildings, 116, 694-702. https://doi.org/10.1016/j.enbuild.2015.11.052

Huang, Y. J., \& Berkeley, L. (2000). A Bottom-Up Engineering Estimate of the Aggregate Heating and Cooling Loads of the Entire US Building Stock Prototypical Residential Buildings. Proceedings of the 2000 ACEEE Summer Study on Energy Efficiency in Buildings, (August), 135-148.

Höppe, P. (2002). Different aspects of assessing indoor and outdoor thermal comfort. Energy and Buildings, 34(6), $661-665$.

IPCC-Buildings. (2014). Lucon O., D. Ürge-Vorsatz, A. Zain Ahmed, H. Akbari, P. Bertoldi, L. F. Cabeza, N. Eyre, A. Gadgil, L. D. D. Harvey, Y. Jiang, E. Liphoto, S. Mirasgedis, S. Murakami, J. Parikh, C. Pyke, and M. V. Vilariño; Change 2014: Mitigation of Climate Change. Contr. Cambridge University Press, Cambridge, United Kingdom and New York, NY, USA. Cambridge, UK and New York.: Cambridge University Press,

Isaksson, C., \& Karlsson, F. (2006). Indoor climate in low-energy houses - an interdisciplinary investigation. Building and Environment, 41(12), 1678-1690.

ISO 7730. (2005). International Standard: Ergonomic of the thermal environment - Analytical ditermination and interpretation of thermal comfort using calculation of the PMV and PPD indices and local thermal comfort criteria (Vol. ISO 7730:2).

Janson, U. (2008). Passive houses in Sweden Experiences from design and construction phase. 
Jensen. S Ö. (1995). Validation of building energy simulation programs “a methodology ," 22, 133-144.

Jeong, J., Hong, T., Ji, C., Kim, J., Lee, M., Jeong, K., \& Koo, C. (2017). Development of a prediction model for the cost saving potentials in implementing the building energy efficiency rating certification. Applied Energy, 189, 257-270. https://doi.org/10.1016/j.apenergy.2016.12.024

Jiboye, A. D. (2014). Significance of house-type as a determinant of residential quality in Osogbo, Southwest Nigeria. Frontiers of Architectural Research, 3(1), 20-27.

Johansson, B., \& Hammerskog, P. (2005). God inomhus miljö - en handbok för fastighetsägare. Fastighetsägarna (Vol. 978-91-977).

Johansson, T., Vesterlund, M., Olofsson, T., \& Dahl, J. (2016). Energy performance certificates and 3-dimensional city models as a means to reach national targets - A case study of the city of Kiruna, 116, 42-57. https://doi.org/10.1016/j.enconman.2016.02.057

Jung, D. K., Lee, D. H., Shin, J. H., Song, B. H., \& Park, S. H. (2013). Optimization of energy consumption using BIM-based building energy performance analysis. In Applied Mechanics and Materials (Vol. 281, pp. 649652). Trans Tech Publ.

Karlsson, J. F. (2006). Multi-dimensional approach used for energy and indoor climate evaluation applied to a low-energy building. Linköping, Swden: Linköping University.

Karlsson, J. F., \& Moshfegh, B. (2006). Energy demand and indoor climate in a low energy building — changed control strategies and boundary conditions. Energy and Buildings, 38(4), 315-326.

Karlsson, J. F., \& Moshfegh, B. (2014). A low-Energy Building Project in Sweden - the Lindås Pilot Project. In Sustainability, Energy and Architecture: Case Studies in Realizing Green Buildings (1st ed., pp. 332-351). Sweden: Academic Press, Elsevier. Retrieved from https://books.google.se/books?hl=sv\&lr=\&id=nkIobvJdjjwC\&oi=fnd\&pg=PA331\&dq=brogården, + lindås\& ots=KfaDreKriS\&sig=fP3TGtwG_TpBTe50iWBK4LUw3wA\&redir_esc $=\mathrm{y} \# \mathrm{v}=$ onepage \&q=brogården\& $\mathrm{f}=\mathrm{f}$ alse

Karresand, H., Molin, A., Persson, J., \& Åberg, M. (2009). How passive are your activities?: An interdisciplinary comparative energy analysis of passive and conventional houses in Linköping.

Kavgic, M., Mumovic, D., Summerfield, A., Stevanovic, Z., \& Ecim-Djuric, O. (2013a). Uncertainty and modeling energy consumption: Sensitivity analysis for a city-scale domestic energy model. Energy and Buildings, 60, 1-11. https://doi.org/10.1016/j.enbuild.2013.01.005

Kavgic, M., Mumovic, D., Summerfield, A., Stevanovic, Z., \& Ecim-Djuric, O. (2013b). Uncertainty and modeling energy consumption: Sensitivity analysis for a city-scale domestic energy model. Energy and Buildings, 60, 1-11. https://doi.org/10.1016/j.enbuild.2013.01.005

Kohler, N., \& Hassler, U. (2012). Alternative scenarios for energy conservation in the building stock. Building Research \& Information, 40(4), 401-416.

Konstantinou, T., \& Knaack, U. (2013). An approach to integrate energy efficiency upgrade into refurbishment design process, applied in two case-study buildings in Northern European climate. Energy and Buildings, 59, pp.301-309.

Kovacic, I., \& Zoller, V. (2015). Building life cycle optimization tools for early design phases. Energy, 92, 409419.

Kuusk, K., Kalamees, T., Link, S., Ilomets, S., \& Mikola, A. (2016). Case-study analysis of concrete large-panel apartment building at pre- and post low-budget energy-renovation. Journal of Civil Engineering and Management, 3730(February), 1-9. https://doi.org/10.3846/13923730.2014.975741

La Fleur, L., Rohdin, P., \& Moshfegh, B. (2017). Measured and predicted energy use and indoor climate before and after a major renovation of an apartment building in Sweden. Energy and Buildings, Under revi.

Lekvall, P., \& Wahlbin, C. (2007). Information för marknadsföringsbeslut.

Lightning Industry, Belysningsbranschen. (2013). En ljusare framtid - Spara energi och miljö med modern 
belysning.

Lindén, A.-L. (2009). Energy efficiency of the household's electricity use. (In Swedish: Hushållsel. Energieffektiviseringar $i$ vardagen). Lund: Sociologisk instituationen.

Lindén, A.-L., Jörgensen, E., \& Thelander, Å. (2009). Energy use. Consumer's decisions and actions. (In Swedish “Energianvändning. Konsumenters beslut och agerande."). Department of Sociology, Lund University.

Liu, L., Akander, J., \& Moshfegh, B. (2014). Neutral Climate and Competivie Gävle region. Gävle Region County Administration.

Liu, L., Rohdin, P., \& Moshfegh, B. (2015). Evaluating indoor environment of a retrofitted multi-family building with improved energy performance in Sweden. Energy and Buildings, 102, 32-44. Retrieved from http://www.sciencedirect.com/science/article/pii/S0378778815003941

Marszal, A. J., \& Heiselberg, P. (2011). Life cycle cost analysis of a multi-storey residential Net Zero Energy Building in Denmark. Energy, 36(9), 5600-5609.

Martinez-Molina, A., Tort-Ausina, I., Cho, S., \& Vivancos, J. L. (2016). Energy efficiency and thermal comfort in historic buildings: A review. Renewable and Sustainable Energy Reviews, 61, 70-85. https://doi.org/10.1016/j.rser.2016.03.018

Martinsson, L., Tengberg, C., Bengtson, J., \& Mjörnell, K. (2015a). Energy efficient renovation in Brogården, Alingsås. Bygg \& Teknik, 2/15. Retrieved from http://byggteknikforlaget.se/energieffektiv-renovering-ibrogarden-alingsas/

Martinsson, L., Tengberg, C., Bengtson, J., \& Mjörnell, K. (2015b). Energy efficient renovation in Brogården, Alingsås. Bygg \& Teknik, 2/15.

Mata, É., Sasic Kalagasidis, A., \& Johnsson, F. (2013). Energy usage and technical potential for energy saving measures in the Swedish residential building stock. Energy Policy, 55, 404-414.

Mattsson., B. (2011). Costs for reducing the energy demand in the Swedish building stock according to national energy targets. Swedish National Board of Housing, Building and Planning.

Mauro, G. M., Hamdy, M., Vanoli, G. P., Bianco, N., \& Hensen, J. L. M. (2015). A new methodology for investigating the cost-optimality of energy retrofitting a building category. Energy and Buildings, 107, 456478.

Milic, V. (2016). Life Cycle Cost Optimization of Historic Buildings - An Assessment of Primary Energy Use and CO2 Emissions. Energy systems, Linköping University.

Molin, A., Rohdin, P., \& Moshfegh, B. (2011). Investigation of energy performance of newly built low-energy buildings in Sweden. Energy and Buildings, 43(10), 2822-2831.

Moosberger, S. (2007). IDA-ICE CIBSE-validation, Test of IDA Indoor Climate and Energy version 4.0 according to CIBSE TM33, issue 3. HTA LUZRN/ZIG.

Moreci, E., Ciulla, G., \& Lo Brano, V. (2016). Annual heating energy requirements of office buildings in a European climate. Sustainable Cities and Society, 20, 81-95. https://doi.org/10.1016/j.scs.2015.10.005

National Board of Housing Building and Planning. (2007). Energy use in buildings: Subgoal 6 - Report for the detailed evaluation of Good Built Environment. Boverket, Karlskrona, Sweden, ISBN: 978-.

Newsham, G. R., Mancini, S., \& Birt, B. J. (2009). Do LEED-certified buildings save energy? Yes, but.... Energy and Buildings, 41(8), 897-905.

Niemelä, T., Kosonen, R., \& Jokisalo, J. (2017). Cost-effectiveness of energy performance renovation measures in Finnish brick apartment buildings. Energy and Buildings, 137, 60-75. https://doi.org/10.1016/j.enbuild.2016.12.031

Norlén, U., \& Andersson, K. (1993). Buildings indoor climate: ELIB (Bostadsbeståndet inneklimat: ELIB). Statens institut för byggnadsforskning, Gävle (Vol. No. 7). 
Olsson, S., Malmqvist, T., \& Glaumann, M. (2016). An approach towards sustainable renovation-A tool for decision support in early project stages. Building and Environment, 106, 20-32. https://doi.org/10.1016/j.buildenv.2016.06.016

Petersen, S., \& Svendsen, S. (2010). Method and simulation program informed decisions in the early stages of building design. Energy and Buildings, 42(7), 1113-1119. https://doi.org/10.1016/j.enbuild.2010.02.002

Petersson, S., \& Werner, S. (2003). Long-term characteriscs of balancing low flow radiator systems (In Swedish: Långtidsegenskaper hos lågflödesinjusterade radiatorsystem). Svenska Fjärrvärmeföreningens Service AB (Vol. ISSN 1402-).

Power, A. (2008). Does demolition or refurbishment of old and inefficient homes help to increase our environmental, social and economic viability? Energy Policy, 36(12), 4487-4501.

PPG Glass Education Center. (2016). How Low-e coating works.

Raftery, P., Keane, M., \& O’Donnell, J. (2011). Calibrating whole building energy models: An evidence-based methodology. Energy and Buildings, 43(9), 2356-2364.

Rohdin, P., Dalewski, M., \& Moshfegh, B. (2012). Indoor Environment and Energy Use in Historic Buildings Comparing Survey Results with Measurements and Simulations. International Journal of Ventilation, 10, 371-382.

Rohdin, P., Molin, A., \& Moshfegh, B. (2014). Experiences from nine passive houses in Sweden-indoor thermal environment and energy use. Building and Environment, 71, 176-185.

Rohdin, P., Palm, J., \& Glad, W. (2010). Low-Energy Buildings-Scientific Trends and Developments. INTECH Open Access Publisher.

Ryan, E. M., \& Sanquist, T. F. (2012). Validation of building energy modeling tools under idealized and realistic conditions. Energy and Buildings, 47, 375-382.

SABO. (2009). Home for millions: Conditions for the rehabilitation of the million homes programme - record years housing (In Swedish: Hem för miljoner: Förutsättningar för upprustning av miljonprogrammet rekordårens bostäder.). Sveriges Allmännyttiga Bostadsföretag, Stockholm.

SABO. (2013). Environmental assessment of energy use in a portfolio recommendation updated version 2013 (In Swedish: Miljövärdering av energianvändningen i ett fastighetsbestånd Rekommendation, uppdaterad version 2013). SABO Swedish Association of Public Housing Companies.

Sabouri, V., \& Femenías, P. (2013). Two Case Studies in Energy efficient Renovation of Multi-family Housing; Explaining Robustness as a Characteristic to Assess Long-Term Sustainability. In A. Håkansson et al (Ed.), Sustainability in Energy and Buildings (pp. 45-57). Springer - Verlag Berlin Heidelberg.

Samuelson, H., Claussnitzer, S., Goyal, A., Chen, Y., \& Romo-Castillo, A. (2016). Parametric energy simulation in early design: High-rise residential buildings in urban contexts. Building and Environment, 101, 19-31. https://doi.org/10.1016/j.buildenv.2016.02.018

Sandberg, N. H., \& Brattebø, H. (2012). Analysis of energy and carbon flows in the future Norwegian dwelling stock. Building Research \& Information, 40(2), 123-139. https://doi.org/10.1080/09613218.2012.655071

Sartori, I., Wachenfeldt, B. J., \& Hestnes, A. G. (2009). Energy demand in the Norwegian building stock: Scenarios on potential reduction. Energy Policy, 37(5), 1614-1627. https://doi.org/10.1016/j.enpol.2008.12.031

SCB. (2015). Number of built apartments \& single-family houses.

SCB. (2016). Sum of apartments and single houses built in Sweden (-1930 2011-).

SEA. (2009). Building insulation - facts, advantages and disadvantages (In Swedish: Att tilläggsisolera hus - fakta, fördelar och fallgropar). Swedish Energy Agency, Eskilstuna (Vol. ET2009:19).

SEA. (2012). Saving and preserving - Energy efficiency in the listed buildings. (In Swedish: Spara och bevara Energieffektivisering i kulturhistoriskt värdefull bebyggelse). Swedish Energy Agency, Eskilstuna (Vol. ET 
2012:02).

SEA. (2016a). Energy in Sweden 2016 (Energiläget 2016). Swedish Energy Agency, Eskilstuna, Sweden (Vol. ET2016:02).

SEA. (2016b). Energy statistics of multi-family buildings. Swedish Energy Agency, Eskilstuna. Eskilstuna. Retrieved from https://www.google.se/search?q=energianvändning+flerbostadshus\&ie=utf-8\&oe=utf$8 \&$ client $=$ firefox-

b\&gfe_rd=cr\&ei=1VmtWLL4KYPD7gTIgo6gAg\#q=energistatistik+för+flerbostadshus +2015

SEA. (2017a). Bio fuel. Retrieved March 8, 2017, from http://www.energimyndigheten.se/effekter-av-varasatsningar/biobranslen-stallde-om-sveriges-fjarrvarmenat/

SEA. (2017b). Smart LED lamps. Retrieved March 8, 2017, from http://www.energimyndigheten.se/tester/testera-o/smarta-led-lampor/

SEPA. (2013). God bebyggd miljö.

Seppanen, O., Fisk, W. J., \& Lei, Q. H. (2006). Effect of temperature on task performance in office environment. Lawrence Berkeley National Laboratory.

Sherman, M. H. (1990). Tracer-gas techniques for measuring ventilation in a single zone. Building and Environment, 25(4), 365-374.

Shimoda, Y., Fujii, T., Morikawa, T., \& Mizuno, M. (2004). Residential end-use energy simulation at city scale. Building and Environment, 39(8 SPEC. ISS.), 959-967. https://doi.org/10.1016/j.buildenv.2004.01.020

SIS. (2007). Svensk Standard SS-EN 15251:2007. Swedish Standards Institute (Vol. SS-EN 1525).

Skanska. (2014). BEEM-UP: Full retrofittning process, documentation of each site. Retrieved January 27, 2017, from www.beem-up.eu

SSNC. (2017). Energy renovation of Million Programme Buildings. Retrieved from http://www.naturskyddsforeningen.se/energirenovera

Steadman, P., Hamilton, I., \& Evans, S. (2014). Energy and urban built form: an empirical and statistical approach. Building Research \& Information, 42(1), 17-31. https://doi.org/10.1080/09613218.2013.808140

Sundell, J., \& Lindvall, T. (1993). Indoor air humidity and the sensation of dryness as risk indicators of SBS. Indoor Air, 3:382.

Sveby. (2012). The standard inputdata of a building (In Swedish: Brukarindata bostäder). Branschstandard för energi i byggnader, Stockholm (Vol. Version 1.).

Swan, L. G., \& Ugursal, V. I. (2009). Modeling of end-use energy consumption in the residential sector: A review of modeling techniques. Renewable and Sustainable Energy Reviews, 13(8), 1819-1835. https://doi.org/10.1016/j.rser.2008.09.033

Swedish Government. (2008). An energy efficient Sweden - A report of energy efficiency investigation. (In Swedish: Ett Energieffektivare Sverige. Delberänkande av Energieffektivseringsutredningen.). Appendix 4, Tabel 2. Government Official Investigations (Vol. SOU 2008:2).

Swedish National Heritage Board. (2017). About the Swedish National Heritage Board. Retrieved March 7, 2017, from http://www.raa.se/in-english/

Swedish Ventilation. (2015). Behovsstyrning ger bättre ekonomi.

The builder. (2015). Good thermostat saves energy (In Swedish: Bra termostater sparar energi).

The property owners. (2014). District heating and environment 2014 (In Swedish: Fjärrvärme och Miljö 2014). The property owners (Fastighetsägarna), Stockholm.

The Swedish Parliament. (2006). The law of Swedish buildings' Energy Certificate - Lag om energideklaration för byggnader (Vol. SFS 2006:9). 
Thollander, P., \& Rohdin, P. (2011). Case study research. Interdisciplinary Energy System Methodology A Compilation of Research Methods Used in the Energy Systems Programme, (45), 12-15.

Thomsen, K. E., Rose, J., Morck, O., Jensen, S. Ø., \& Østergaard, I. (2015). Energy consumption in an old residential building before and after deep energy renovation. Energy Procedia, 78, 2358-2365. https://doi.org/10.1016/j.egypro.2015.11.398

Thomsen, K. E., Rose, J., Mørck, O., Jensen, S. Ø., Østergaard, I., Knudsen, H. N., \& Bergsøe, N. C. (2016). Energy consumption and indoor climate in a residential building before and after comprehensive energy retrofitting. Energy and Buildings, 123, 8-16. https://doi.org/10.1016/j.enbuild.2016.04.049

Tian, W. (2013). A review of sensitivity analysis methods in building energy analysis. Renewable and Sustainable Energy Reviews, 20, 411-419. https://doi.org/10.1016/j.rser.2012.12.014

Tinytag. (2015). Tintytag - Temperature and humuidity loggers. Intab http://intab.se/catalog/products/TGP4500tinytag-plus-2-temperatur-och-luftfuktighet.

UFOS. (2013). Ways to reach the 2050 energy target for the property owners - A study of success factors (In Swedish: Så når offentliga fastighetsägare 2050 - målen. En studie av framgångsfaktorer). Swedish Association of Local Authorities and Regions (Utveckling av fastighetsföretagande i offentlig sektor) (UFOS) (Vol. ISBN 978-9).

Uihlein, A., \& Eder, P. (2010). Policy options towards an energy efficient residential building stock in the EU-27. Energy and Buildings, 42(6), 791-798. https://doi.org/10.1016/j.enbuild.2009.11.016

Vidén, S. (2012). Rekordårens bostäder - en viktig resurs för hållbar utveckling. In B. Johansson (Ed.), Miljonprogrammet - utveckla eller avveckla? Stockholm: Forskningsrådet Formas.

Wang, Q., \& Holmberg, S. (2014). A methodology to assess energy-demand savings and cost effectiveness of retrofitting in existing Swedish residential buildings. Sustainable Cities and Society, 14(C), 254-266. https://doi.org/10.1016/i.scs.?.014.10.007

Warfvinge, C., \& Dahlblom, M. (2012). Projektering av VVS-installationer (Vol. 1:5). Lund: Studentlitteratur.

Wikells building calculation. (2016). Sections data - Building calculation.

Xu, Z., Guan, X., Jia, Q.-S., Wu, J., Wang, D., \& Chen, S. (2012). Performance analysis and comparison on energy storage devices for smart building energy management. IEEE Transactions on Smart Grid, 3(4), 2136-2147.

Yin, R. K. (2009). Case study research: Design and methods (4th ed.). Sage Publications, Thousand Oaks, CA.

Zagorskas, J., Zavadskas, E. K., Turskis, Z., Burinskienė, M., Blumberga, A., \& Blumberga, D. (2014). Thermal insulation alternatives of historic brick buildings in Baltic Sea Region. Energy and Buildings, 78, 35-42. 



\section{Appended Papers}

The articles associated with this thesis have been removed for copyright reasons. For more details about these see:

http://urn.kb.se/resolve?urn=urn:nbn:se:liu:diva-137445 